\title{
Old structures in relation to soil conditions
}

\section{J. KERISEL*}

This Paper analyses the long-term behaviour of old structures, their settlements, instantaneous rotations and their response to superimposed loads. In the context of additional loads, it is shown how little reliance can be placed in 'reserve resistance'; especially, for structures with a very small factor of safety, very small superimposed loads applied in a continuous direction over a long period of time may cause significant deformations. At the same time, a study is made of the instantaneous centre of rotation of a building in danger. In discussing famous churches, rotations due to the long-term effects of eccentric loads and of differential settlements created by an unequal loading distribution over a given surface are described. A long-term progressive creep of a fill in Stockholm over six centuries is also discussed. In the second part of the Paper, the vulnerability of old buildings to settlements caused by open excavations and tunnelling is studied; the notion of surface radii of curvature is proposed. Finally, the subject of the long-term stability of old tunnel linings is examined.
On examine les comportements à long terme de vieilles structures. On analyse leurs tassements et rotations instantanés et à long terme et leur comportement sous des forces additionnelles; il est montré à cet égard combien peu il faut compter sur une 'réserve résistance'; et même, pour des structures avec un très faible coefficient de sécurité, de très petits efforts complémentaires agissant dans le même sens pendant des siècles, amènent des mouvements notoires. On analyse au passage la position du centre instantané de rotation dans un édifice en danger. A propos d'églises notoires, sont décrites les rotations à long terme produites par des forces excentrées et les tassements différentiels créés par d'inégale distribution des forces contenues dans un même périmètre. L'auteur met en relief un fluage progressif de remblais pendant six siècles à Stockholm. Dans la deuxième partie de l'exposé, la vulnérabilité des immeubles anciens aux tassements créés par les tunnels et les fouilles au voisinage est examinée; on propose des critères de rayons de courbure. Enfin, la question de stabilité à long terme des vieilles voûtes de tunnels est examinée.

The large audience at the Rankine Lectures and the quality of the previous contributions have made the annual lecture one of the great events in the life of our International Society and it is for this reason that I am very pleased, Mr President, to have been asked to deliver this Fifteenth Lecture.

I have chosen to speak to you about old structures in relation to soil conditions. At the present time, when there are those among us who devote their attention to the construction of nuclear facilities, it may appear peculiar and pointless to glance backwards towards Gothic and earlier architecture. I must therefore first of all justify my subject and outline my plans, both practically and intellectually.

From the practical point of view, the recent collapse of old tunnels, ${ }^{1}$ the failure of old retaining walls, the vulnerability of ancient buildings to the effects of adjacent deep excavations, the long-term movements of old buildings, bring home to us that nothing is eternal and that everything continues to evolve: ideas of residual strength apply equally to soils and to old materials used in construction. To a soils engineer, it is venturing into a new domain to consider the behaviour in old age of building materials in relation to soils.

However, on an intellectual level, Burland and Wroth (1974), general reporters at the Cambridge conference on settlements a year ago, pointed out that the long-term performance of a

* Simecsol Etudes, 115 rue Saint-Dominique, 75007, Paris.

1 For example, the railway tunnel at Vierzy, France in 1972 and the abandoned railway tunnel at Canterbury, England in 1974. The first was constructed about 1850 and the second about 1830 . 


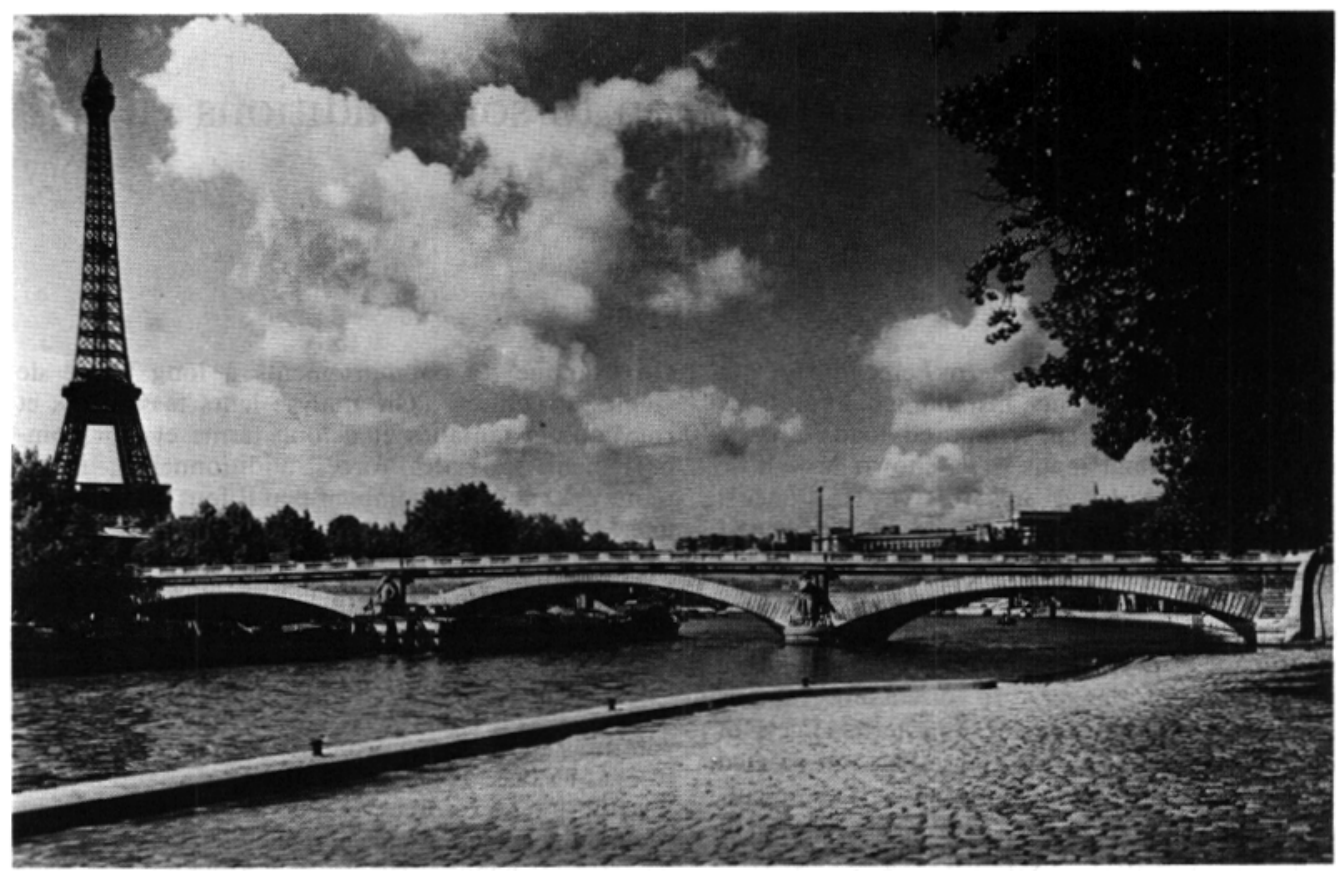

Fig. 1. Pont de l'Alma

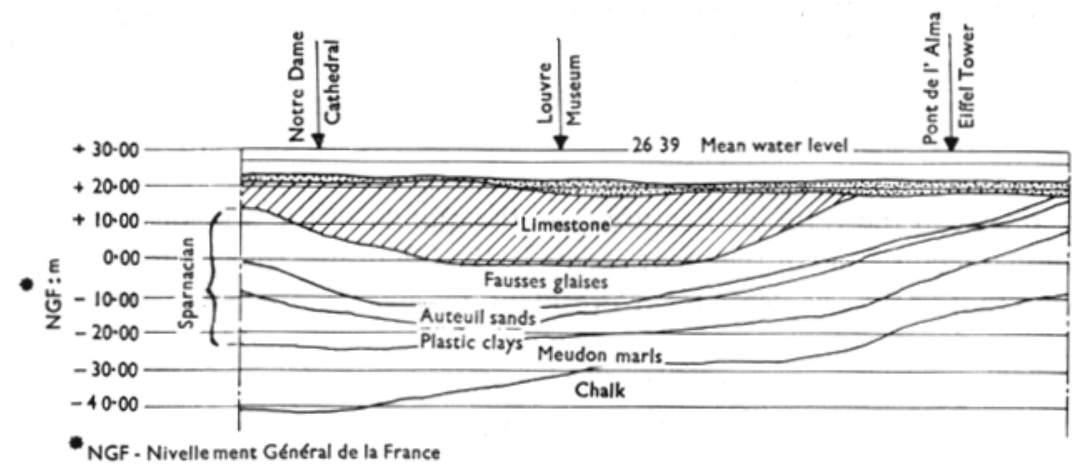

Fig. 2. Longitudinal geotechnical profile along River Seine in Paris

structure must not be overlooked. The observation of the deformation of planes of weakness, together with a study of the geometry of fissures and joints, makes possible the definition of the criteria being sought and highlights those parameters which are important and those which control the situation. On approaching the subject, it is quickly appreciated that, in order to understand the foundations of old buildings, a general picture of the behaviour of the whole structure, together with the soil, is necessary and for this reason the study of the deformation of old masonry will be elaborated. Unfortunately ancient documents are rarely found, old survey measurements are often suspect or non-existent and restoration following damage inflicted during wars has often masked the phenomena of interest; I can therefore treat only certain typical cases. 


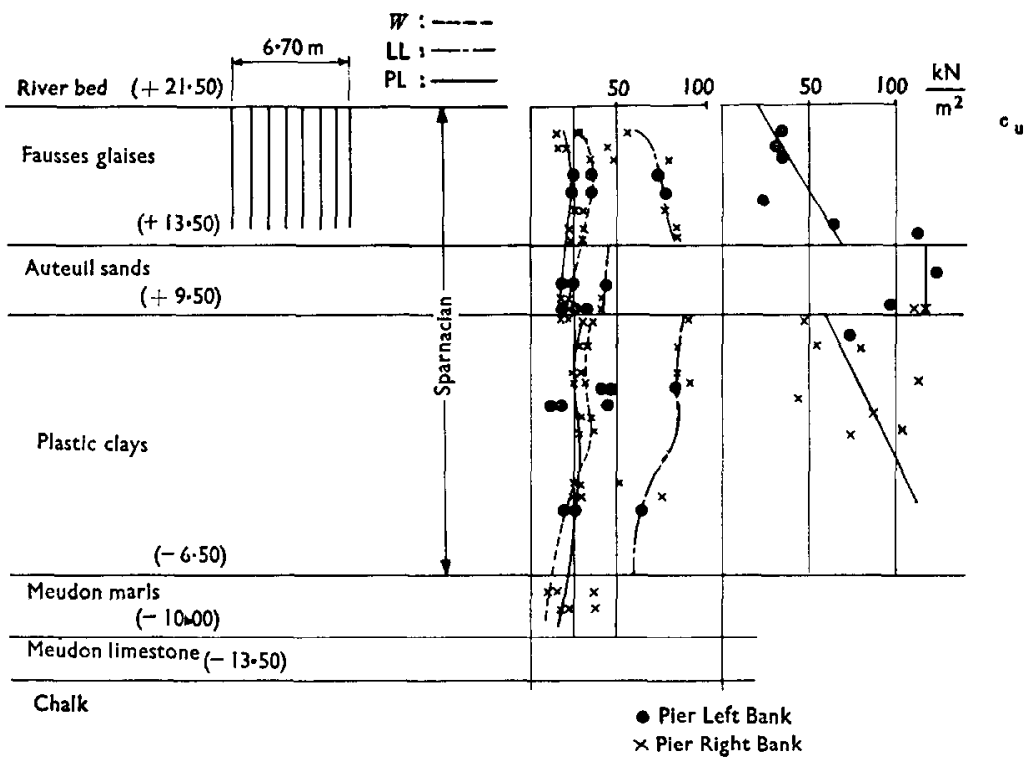

Fig. 3. Geotechnical profile under the two piers

The first part of the Paper will examine the old superstructures of buildings on shallow foundations, which covers the majority of ancient buildings; several low structures will be studied and then several high buildings. The second part of the Paper will deal mainly with buried structures. Two notable pieces of work have been carried out on a similar subject (Leggett, 1973; Schultze, 1971).

\section{PART I: OLD SUPERSTRUCTURES}

Pont de l'Alma, Paris (1855-1972); excessive stresses on soil

This bridge (Fig. 1) offers a good example of both an early generalization in soil mechanics and of the adaptation of a masonry structure to accommodate large differential settlements. As is seen on the section across the bed of the Seine (Fig. 2), the geological strata under Paris dip towards the centre of the city and then rise again, such that the limestone disappears just upstream of the Pont de l'Alma, being superseded by clay strata.

The decision to proceed with the construction of the bridge was taken suddenly in 1854 and the short programme fixed by Napoleon III did not permit engineers to make a detailed study of the soil; they believed that the limestone existed at a shallow depth, but in fact the $98000 \mathrm{kN}$ of dead weight from each of the river piers was transmitted to a $6.7 \times 27.5 \mathrm{~m}$ rectangular foundation slab resting on the clay, by means of 272 small section piles $7 \mathrm{~m}$ long, very closely spaced, each covering an area of $0.635 \mathrm{~m}^{2}$. The combined pile and slab assembly served therefore as a foundation block exerting a mean foundation stress of $533 \mathrm{kN} / \mathrm{m}^{2}$. Fig. 3 shows that the pile tips do not quite reach the base of the first bed of clay (the fausses glaises-so named because they contain inclusions of pyrites). These clays are characterized by $c_{\mathrm{u}}$ values ranging between $20 \mathrm{kN} / \mathrm{m}^{2}$ and $70 \mathrm{kN} / \mathrm{m}^{2}$ and a thickness of $8 \mathrm{~m}$. They lie directly over a $4 \mathrm{~m}$ thick layer of Auteuil sands; this is actually a succession of sands and marls of somewhat greater strength ( $c_{\mathrm{u}}$ slightly above $100 \mathrm{kN} / \mathrm{m}^{2}$ ), the strength value being just sufficient to avoid the risk of punching of the piles. However, below this formation is found a $15 \mathrm{~m}$ thick bed of plastic 


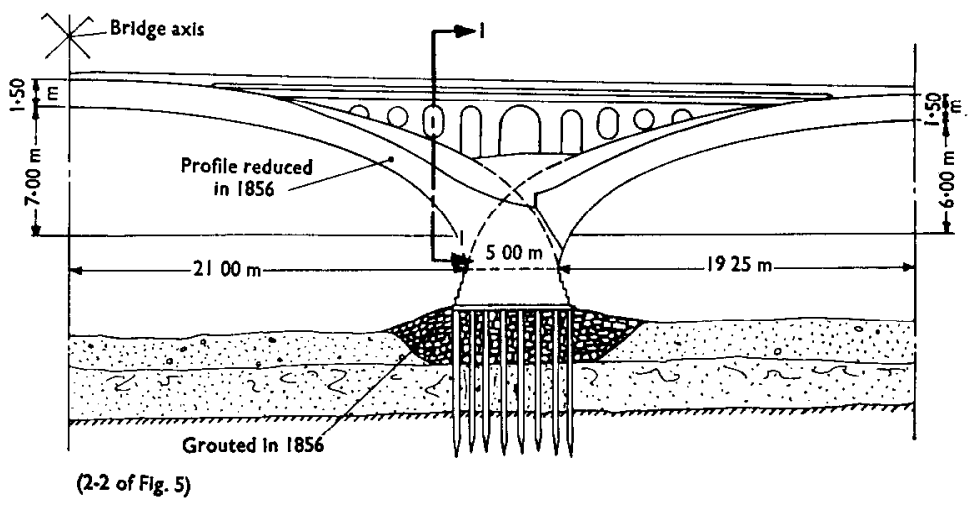

Fig. 4. Cross-section of the bridge

clay $^{2}$ (in which $c_{\mathrm{u}}$ falls to only $60 \mathrm{kN} / \mathrm{m}^{2}$ ), the presence of which explains the long-term settlement of the bridge.

On 29 October, 1855, when the bridge was already in use (Fig. 4), an attempt was made to remove the arch centering, but as the bridge settled as much as the centering was lowered it was not even possible to separate the arches from their formwork. Faced with this unacceptable situation and after having stopped the flow of traffic over the bridge, it was decided to lighten the structure. The fill above the vaults was removed and the road supported on a series of seven brick arches along a longitudinal axis resting on the two spandrels and on six brick walls which were themselves honeycombed (Figs 4 and 5). In addition, an attempt was made to inject cement around the piles. Following the re-opening to traffic on 2 April, 1856, the settlements continued to increase and reached $37.5 \mathrm{~cm}$ on the left pier and $52.0 \mathrm{~cm}$ on the right pier. At this stage it was decided to proceed with a second lightening of the structure and to reduce the thickness of the arch haunches at the springing (Fig. 4). The dead load was thus reduced to $89500 \mathrm{kN}$ per pier and it was possible to open the bridge to traffic; but the settlements continued with the elapse of time (Fig. 6).

Two factors prevented stabilization of the situation. The first concerns the live loads, which originally were some $3000 \mathrm{kN}$ per pier, but which had increased by 1970 to $12000 \mathrm{kN}$, with a much higher traffic density accompanied by stronger vibrations. The second factor concerns the floods. By virtue of the obstruction caused by the bridge, flooding of the Seine has exerted pressure on the upstream spandrel, thus reversing the bending moment on the bridge and inducing greater settlements on the downstream side. The flood of 1910 was

Table 1. Settlement of the Pont de l'Alma

\begin{tabular}{l|c|c|c|c}
\hline & \multicolumn{4}{|c}{ Settlement, cm } \\
\cline { 2 - 5 } & \multicolumn{2}{|c}{ Left Bank } & \multicolumn{2}{c}{ Right Bank } \\
\hline & Abutment 1 & Pier 2 & Pier 3 & Abutment 4 \\
\hline Upstream & 49 & $61 \cdot 5$ & $62 \cdot 0$ & 27 \\
Downstream & 51 & $67 \cdot 5$ & 87.5 & 37 \\
\hline
\end{tabular}

2 The Parisian plastic clay belongs, like the London Clay, to the Ypresian geological period, but the former occurred during the Sparnacian sub-period whereas the latter occurred during the Cuisian sub-period. The Parisian plastic clay has not been overconsolidated by glaciers. 


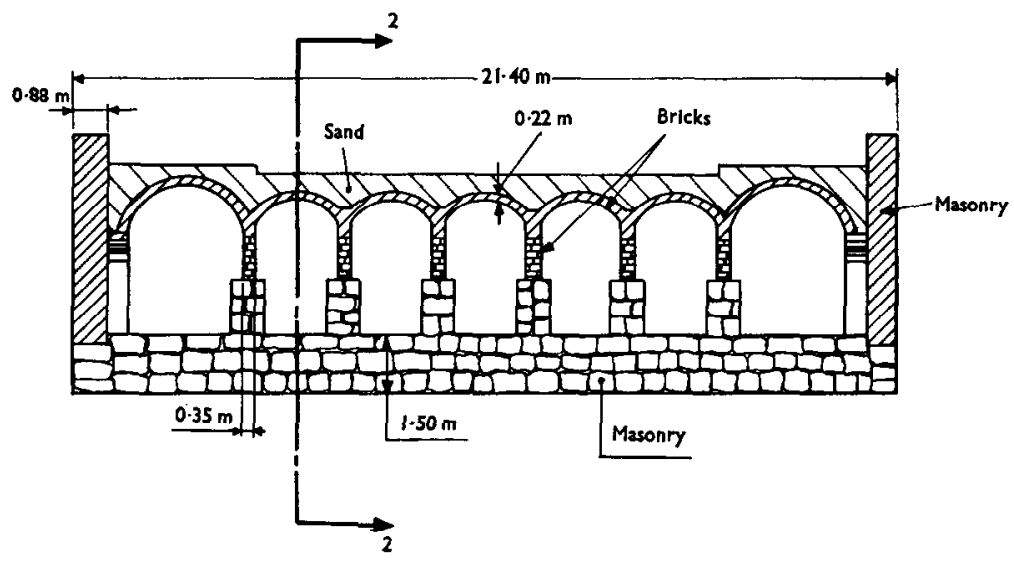

Fig. 5. 1-1 of Fig. 4
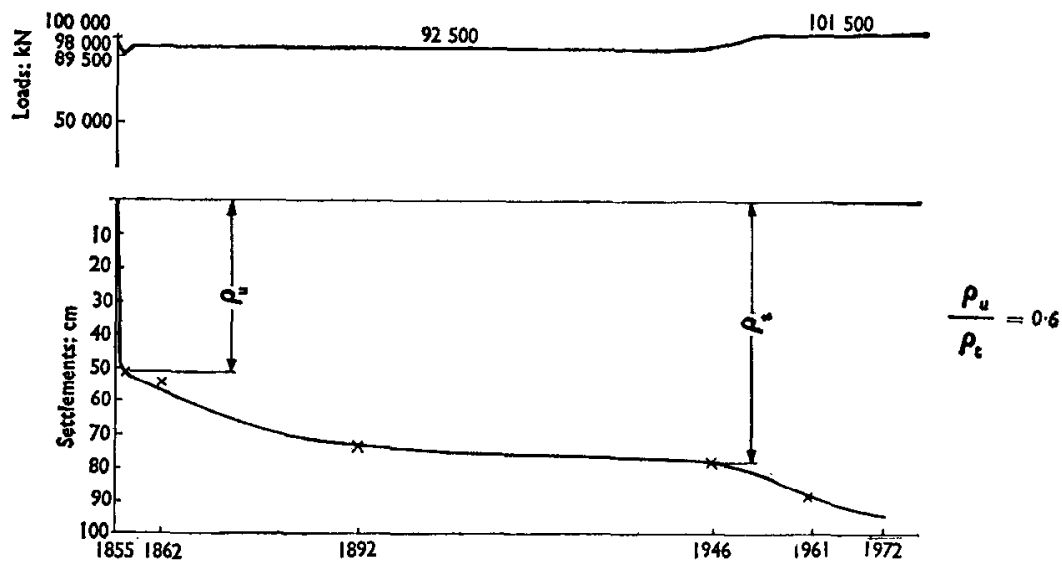

Fig. 6. Pier 3 settlements (Right Bank downstream): evolution during 117 years

particularly important. The evolution of settlement and rotation towards the downstream side during 117 years has not been due to a constant applied load; the loads initially decreased at the end of construction, and increased thereafter with time. The mean annual deformation about 1920 was no more than $1 \mathrm{~mm}$, but by virtue of the increased traffic it had become approximately $5 \mathrm{~mm}$ by 1950 . By 1970 the upstream and downstream piers had settled by the amounts shown in Table 1. The distances between abutment 1 and pier 2, between piers 2 and 3, and between pier 3 and abutment 4 are $40 \cdot 74,48$ and $40 \cdot 75 \mathrm{~m}$ respectively.

Figure 6 shows that the ratio $\rho_{\mathrm{u}} / \rho_{\mathrm{t}}$ of the immediate settlement to the total settlement here is $60 \%$, whereas for normally consolidated clay an allowance of $20 \%$ is generally made. This latter value can therefore be considered admissible only for pressures much less than the limiting pressure. The bridge has therefore been subjected to a notable torsional movement over the section between pier 3 and abutment 4 . The angular strain $\alpha_{3}$ at pier 3 downstream (Fig. 7) is therefore given by $\alpha_{3}=(87 \cdot 5-37) /(4075)+(87 \cdot 5-67 \cdot 5) /(4800) \simeq 1 / 60$, and the sagging ratio $\Delta / L$ by $\Delta / L=35 / 8875 \simeq 1 / 253$. The differential settlement of pier 3 is $35 \mathrm{~cm}$, which is 


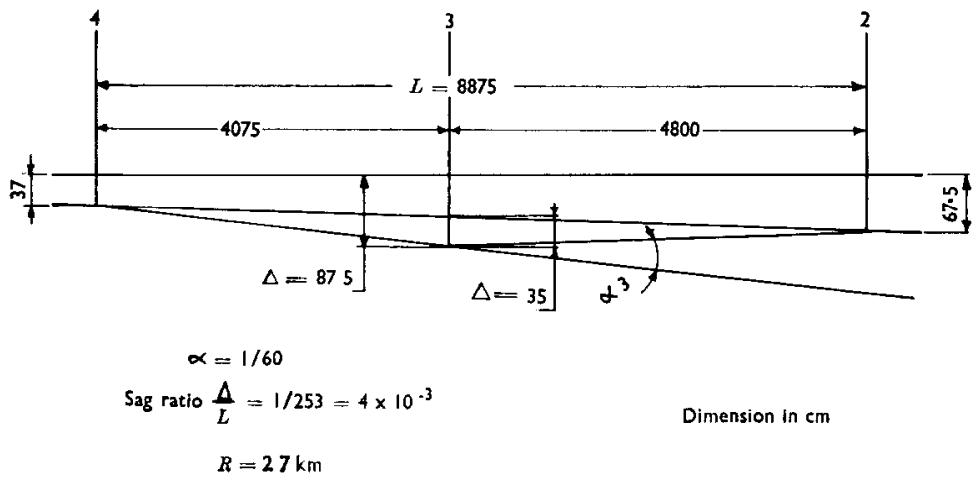

Fig. 7. Pier 3 (downstream) in relation to piers 2 and 4

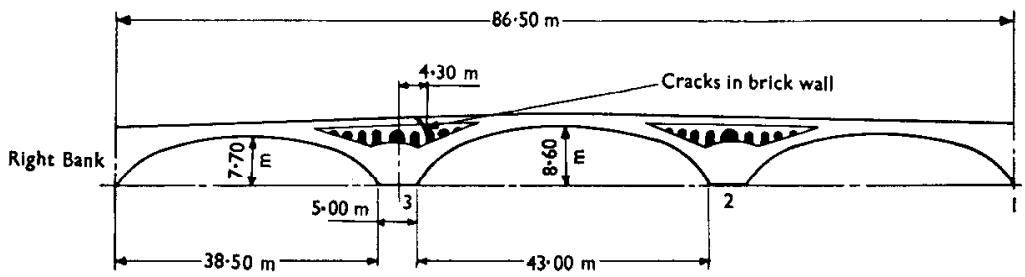

Fig. 8. Location of cracks observed since 1960

more than half the absolute mean settlement of the pier 2 and abutment 4 , which can be calculated as $(67 \cdot 5+37) / 2=52 \cdot 2 \mathrm{~cm}$. The radius of curvature can be calculated approximately as $44^{2} /(2 \times 0.35)=2 \cdot 7 \mathrm{~km}$.

During the life of the bridge, the stress concentrations around the openings left to reduce the dead weight led to the formation of fine cracks which appeared in 1960 (Fig. 8). The bridge tended to act as an arch hinged at the crown and spanning the points 2 and 4 . This hinge was situated almost at the middle of the span $2-4$, pier 3 behaving as a partially suspended keystone.

$\mathrm{Up}$ to the time of demolition, the spandrels of the bridge even in the transversal direction, intersected by the cracks in the brick walls, were not cracked to any significant degree. All that could be seen at the junction of the two materials was a variation in the breadth of the masonry joints. This therefore provides a good example of two types of masonry, brick and dressed stone, which reacted differently to the same sagging ratio (1/253). Both types of masonry, with slow-setting thick mortar joints, permitted a great deal of tolerance to movement, both during de-centering and throughout the life of the structure. The Pont de l'Alma became too low and furthermore was too narrow; it has been re-built in high strength steel with a single pier in the river, founded on barrettes taken down to the chalk (Fig. 9). The new bridge has two unequal arches, of which the larger spans the expressway along the quay on the Left Bank as well as the navigation channel of the Seine.

Rennie's London Bridge (1831-1965); excessive stresses on soil

The characteristics of this bridge, were described recently by Nash (1973). In comparison with the Pont de l'Alma, the span between piers was approximately the same; the deck of the bridge was higher above the bed of the river. With the same width at deck level, the load on 


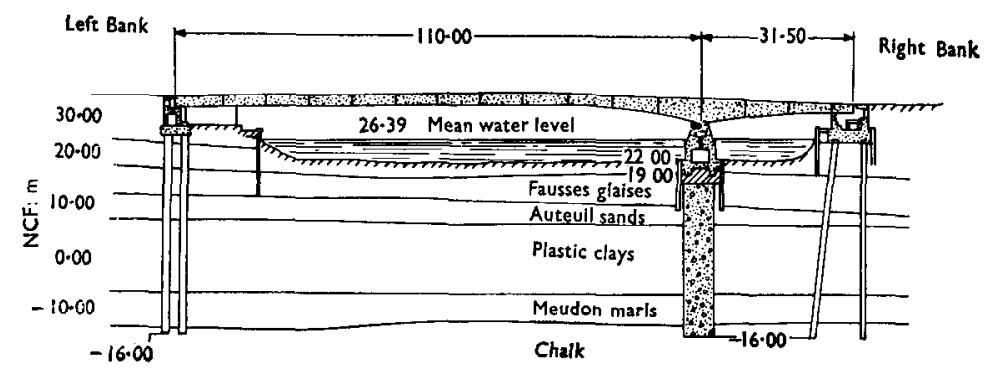

Fig. 9. Foundations of new bridge

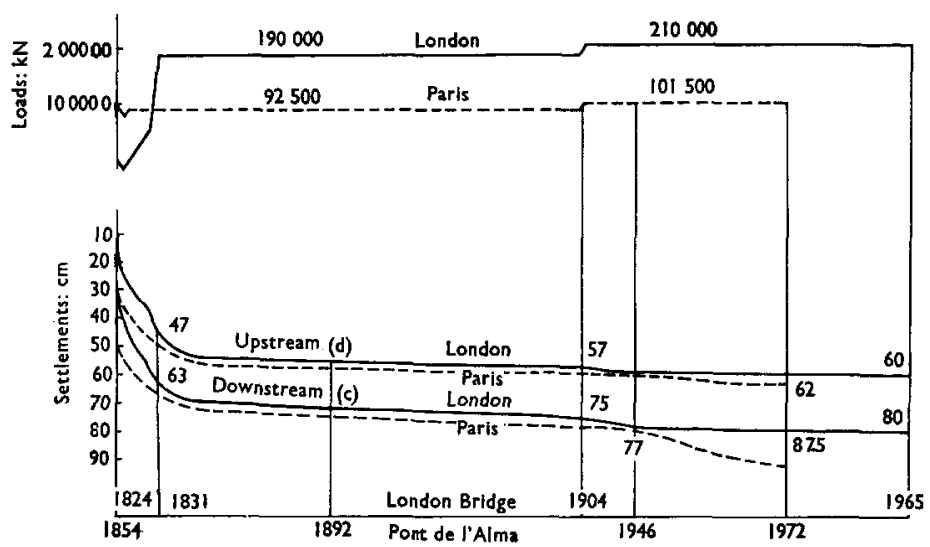

Fig. 10. Comparison of settlements between Pier 3 (London Bridge) and Pier 3 (Pont de I'Alma)

each pier $(190000 \mathrm{kN})$ was twice that of the Pont de l'Alma. Without taking into account the mobilized skin friction of the 200 piles per pier, each $6 \mathrm{~m}$ long and carrying the loads down to the London Clay, the mean stress on the clay was about $640 \mathrm{kN} / \mathrm{m}^{2}$ (compared with 533 $\mathrm{kN} / \mathrm{m}^{2}$ at the Pont de l'Alma). The strength of the London Clay was certainly higher (160 $\mathrm{kN} / \mathrm{m}^{2}$ at the pile tips) than that of the corresponding Parisian clay, but it had been remoulded by disturbance during the construction of the cofferdams. The surface of the clay rose by an amount equal to the volume of the piles that had been driven and a tilt of about $15 \mathrm{~cm}$ was observed by a commission, which included Thomas Telford, set up in 1831. The commission arranged for numerous levels to be taken along the bridge in September 1831 and it was possible for Anderson to check the same points 134 years later (Nash, 1973).

There are no firm records for the settlements during the construction period (1824-1831) but there are extensive records taken during the period 1831-1965. Telford's commission concluded in 1832 that considerable settlement had occurred during construction, ${ }^{3}$ yet the bridge had become stable. It was known from evidence given to the commission by the resident engineers that the springing points of the arches should be $7 \mathrm{ft} 6 \mathrm{in}$. under HWST. On the assumption that this was so, as Telford accepted, Nash was able to calculate the datum levels, both intended and actual, in September 1831, and it is from his comparison table that the settlement graphs reproduced in Fig. 10 have been deduced for pier 3 (the third from the north bank) as a comparison with pier 3 of the Pont de l'Alma.

${ }^{3}$ Rennie (1875) wrote that the piles had settled some 3 in. when the 12000 tons from the arch were transferred to them but it appears that this was an underestimate. 


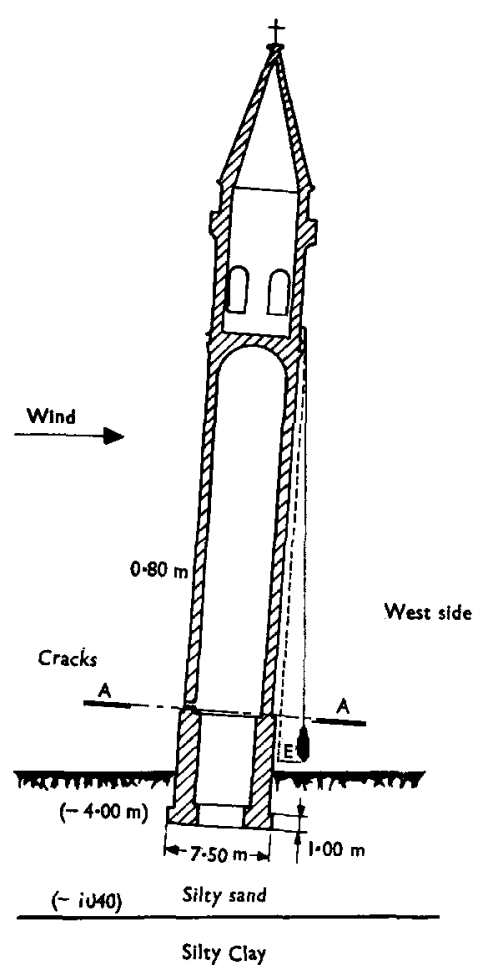

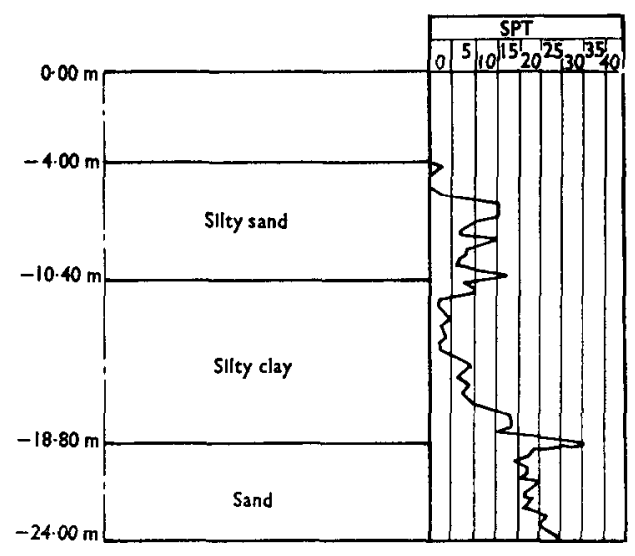

Fig. 11 (left). Cross-section of Burano bell-tower Fig. 12 (above). Geotechnical profile

In both cases, there was a partial soil failure at the early stages in the lives of the bridges with correspondingly high settlement rates and tilting towards the downstream side. ${ }^{4}$ No reserve resistance was available to withstand additional loading without further settlements.

Tall masonry buildings; excessive stresses on soil

The bell-tower at Burano. Built on the edge of the Venice lagoon, about 400 years ago (Fig. 11), with a height of $53 \mathrm{~m}$ and a square base $7.5 \mathrm{~m}$ wide, this tower has a slenderness ratio of about seven. With a mass of $1600 \mathrm{t}$, the vertical stresses applied at the square base are $\left(1600 \times 10^{3} \times 9 \cdot 81\right) /(7 \cdot 50 \times 7 \cdot 50)=280 \mathrm{kN} / \mathrm{m}^{2}$. Between 10.0 and $18.5 \mathrm{~m}$ in depth there exists a bed of clay, with a very soft upper layer (SPT $N$ value of 2 at $11 \mathrm{~m}$ depth, $c_{\mathrm{u}}$ lying between 10 and $20 \mathrm{kN} / \mathrm{m}^{2}$ (Fig. 12). Overlying this clay bed is a sand layer within which the tower is founded $4 \mathrm{~m}$ below the surface. It is the presence of the clay bed (at a depth below the foundation less than the breadth of the foundation) that gave rise to the large settlements of the bell-tower. These were measured regularly, and certain parts of the pedestal of the foundation which were visible at the beginning of this century have since moved underground.

Even during construction, which continued for fifty years, the bell-tower leant towards the west; the builders tried to compensate for this inclination as the height of the tower was increased, as can be seen from the curvature of the facing on the west side. This tilting was without doubt caused by the transverse heterogeneity of the soil, but it was also affected by the east-west winds that blow across the lagoon.

\footnotetext{
4 It is less obvious that this tilting results only, as in Paris, from flooding, Rennie's bridge being heavier and higher; it may also be due to the erosion of the river bed downstream of old London Bridge (1176-1834) which was replaced by Rennie's bridge. The overall width of the numerous piers of the old bridge at low water was three-quarters of the distance between the abutments.
} 

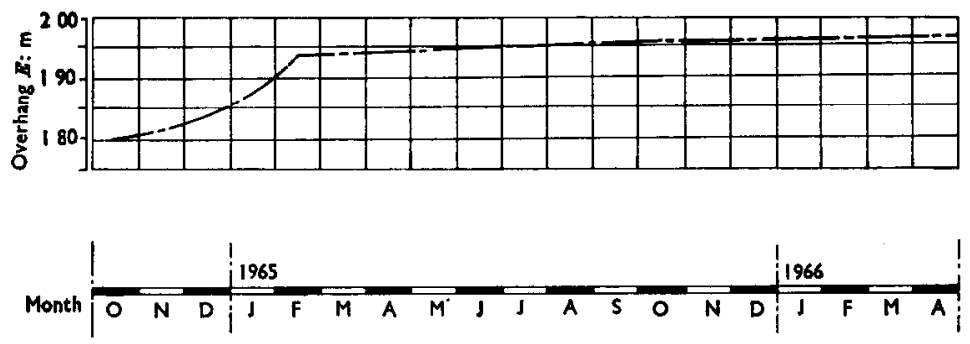

Fig. 13. Evolution of the overhang during repairs

Fig. 14. Tower of Pisa

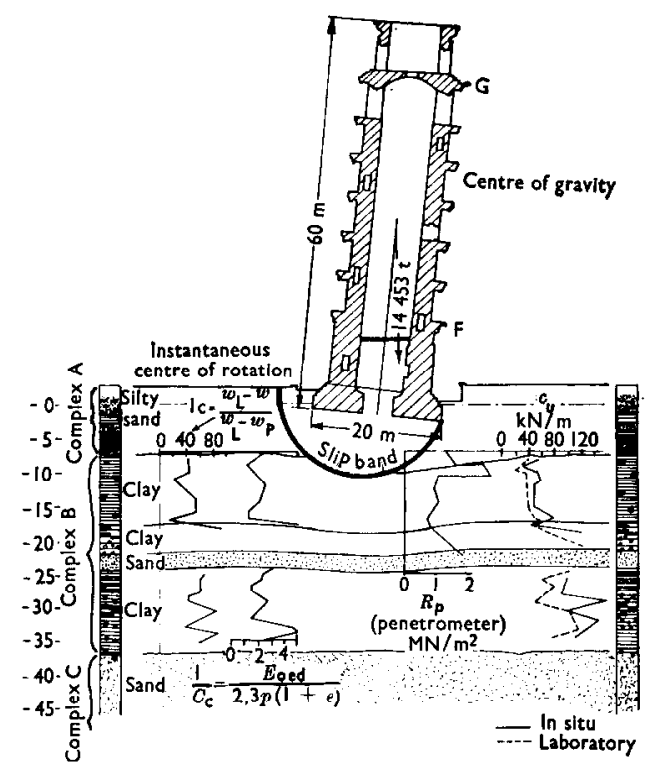

The rotation of the bell-tower did not cease to increase until 1964, when the question was raised as to demolishing the tower. The overhang $E$ measured in 1952 (Fig. 11) was $1.81 \mathrm{~m}$, corresponding to an inclination of $1 \cdot 81 / 31 \cdot 15=1 / 17$. The vertical through the centre of gravity passed approximately $1 \mathrm{~m}$ from the western edge of the foundation and, in a strong wind, the resultant was very close to the western edge. In effect a wind applying a pressure or $2 \mathrm{kN} / \mathrm{m}^{2}$ gives a resultant of $450 \mathrm{kN}$ at a height of $27 \cdot 10 \mathrm{~m}$, which corresponds to an eccentricity of $(450 \times 27 \cdot 10 \mathrm{~m}) /(1600 \times 9.81)=0.76 \mathrm{~m}$, stressing the eastern and western edges of the foundation by $\pm 280 \times(6 \times 0 \cdot 76) / 7 \cdot 50= \pm 172 \mathrm{kN} / \mathrm{m}^{2}$ which is considerable, in view of the low strength of the upper part of the clay layer, in spite of the reduction in stress with depth through the sand deposit.

The equilibrium is still less favourable in the neighbourhood of section AA, where the belltower sits on its pedestal. When the wind blows, the resultant passes outside the masonry section, leading to uplift on the side exposed to the wind, thus causing cracks to appear. The bell-tower at Burano has been quoted because of its high slenderness, as for 400 years it continued to rotate and is therefore one of the rare cases where the resultant passes outside the section of the structure.

The Italian firm, Fondedile, proposed in 1964 to repair the masonry and to stabilize the edifice by means of 'pali radici', intersecting in section AA, tying together the pedestal and 
Fig. 15. Inclination of the tower with time

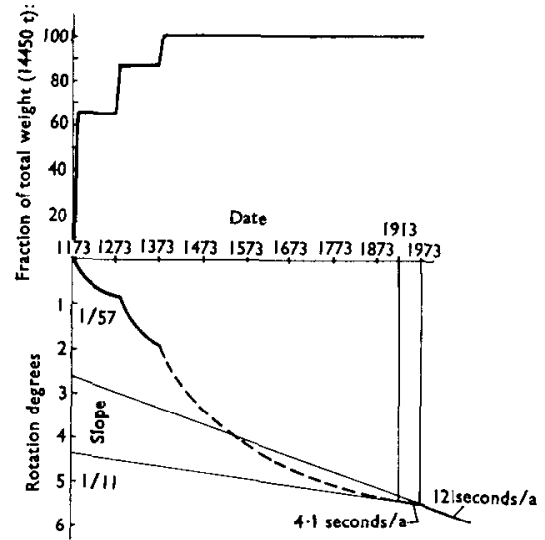

the soil over a depth of $25 \mathrm{~m}$. The works were carried out between October 1964 and February 1965. Fig. 13 shows the development of the tilting during these works. Inclination now has been stabilized at $E=1.95 \mathrm{~m}$, corresponding to a displacement to height ratio of $1 / 16$.

The Tower of Pisa. The slenderness of the tower (Fig. 14) is not particularly significant $(60 \mathrm{~m}$ in height, approximately $20 \mathrm{~m}$ in diameter), but it has proved interesting in that the monument has for eight centuries moved in space like a solid undeformed body ${ }^{5}$ with a mechanism that it is possible to describe today through a study of the constructional details of the tower and from the measurements taken of the principal characteristic movements since 1911.

The geotechnical data are as follows. The towcr is constructed on a bed of more or less silty sand, above some $30 \mathrm{~m}$ of clay, which is intersected by a bed of sand $5 \mathrm{~m}$ thick. All around the tower, the clay has an undrained strength that increases progressively with depth from $40 \mathrm{kN} / \mathrm{m}^{2}$ to $120 \mathrm{kN} / \mathrm{m}^{2}$. The mass of the tower is $14450 \mathrm{t}$ and exerts a mean pressure on the soil of $480 \mathrm{kN} / \mathrm{m}^{2}$, which is twelve times the undrained strength of the upper part of the clay. It is therefore inevitable that the inequality between the mechanical properties of the silty sand and the upper clay leads to rotation accompanied by significant settlement.

A settlement calculation based on compressibility coefficients measured in the oedometer tests on undisturbed samples over a depth of $30 \mathrm{~m}$ gives settlement values that are approximately in agreement with the total observed settlement of $2.50 \mathrm{~m}$. The actual degree of consolidation is almost one. It can be calculated that, in the course of this consolidation, the cohesion of the softest upper clay has increased to $110 \mathrm{kN} / \mathrm{m}^{2}$.

Without going into detail, the principal characteristics of the mechanism of the movements (Fig. 15) will be discussed. From 1173 to 1178 , two-thirds (in terms of weight) of the tower was constructed; it tilted towards the northeast and the inclination doubled to $1 / 182$ by 1272 , the year construction re-started. This continued for a further six years before $86 \%$ of the final weight was in place. The tower then leant towards the northwest; in 1370 , the tower

Table 2. Rotation of the Tower of Pisa

\begin{tabular}{l|c|c|c|c|c|c}
\hline Decade & $1918 / 28$ & $1928 / 38$ & $1938 / 48$ & $1948 / 58$ & $1958 / 68$ & $1968 / 78$ \\
\hline $\begin{array}{l}\text { Increase in rotation during } \\
\text { decade, seconds }\end{array}$ & 42 & 80 & 44 & 36 & 53 & $125(?)$ \\
\hline
\end{tabular}

${ }^{5}$ The masonry is perfectly bedded together and is of excellent quality with a minimum number of cracks. 


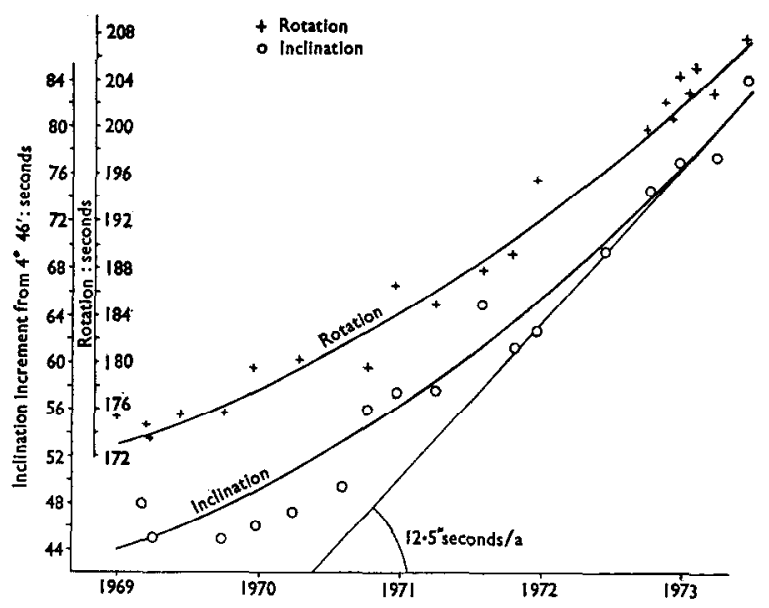

Fig. 16. Inclination and rotation between 1969 and 1973

was completed and the inclination was towards due south, as it is today. Whereas the tilt was $1 / 31$ in $1370,{ }^{6}$ today it is $1 / 10 \cdot 8$ (19400 seconds). ${ }^{7}$

After a deceleration of movement over the past five-and-one-half centuries, movements are today tending to accelerate. A minimum speed of rotation took place in the decade 19181928 (42 seconds in ten years). Since that time, the speed of rotation has developed as shown in Table 2. The important acceleration between 1928 and 1938 is connected with the execution of nearby boreholes. The absolute minimum took place during the period 1948-58. Measurements published very recently show a rotation of 52 seconds for 1968-1973 and 11 seconds for the single year 1974. Actually, the resultant through the centre of gravity approaches the limit of the central quarter. Up to 1950 , during the consolidation of the clay, the improvement in its mechanical properties compensated for the additional moment due to rotation, but these mechanical properties have now reached a maximum and it is probably this dangerous acceleration that was the motive in formulating the competition organized in 1973 by the Italian government, to stabilize the tower.

In this rotation of the tower's axis in the north-south plane ${ }^{8}{ }^{\text {i.e. }}$ about the east-west axis, one might ask what is the position of the instantaneous centre of rotation in this plane. This question is applicable as the tower has not been structurally deformed. Moreover, it is possible, since 1911 , from a point situated $80 \mathrm{~m}$ to the west of the tower, to study the horizontal movements (Fig. 14), which the Italians have measured from points $F$ and $G$ on the first and seventh cornices, and at the same time to consider levels taken on a number of points on the pedestal. By a method of successive approximations the instantaneous centre of rotation can be determined. It is situated on the base of the tower on the up-hill side (Fig. 14). One can intuitively expect the tower to form, or cause to form, in the soil the curved slip surface indicated by the heavy line in Fig. 14. At the same time as this rotation is produced in the meridian plane, there is another rotation (azimuthal rotation) around the geometric axis of the tower in a counter-clockwise direction as viewed from above, the angle of this second rotation being proportional to the angle of meridian rotation in the ratio 0.95 from 1969 to 1973 (Fig. 16).

${ }^{6}$ Differences in inclination of successive courses of masonry and vertical measurements around the tower have provided the early data on the rotation of the tower.

7 One explanation of the tilting of the tower could lie in the presence of wedge-shaped lenses of silt in upper layers.

${ }^{8}$ In fact, north-northwest-south-southeast at $2^{\circ} 26^{\prime}$ to the meridian. 
The tower is rotating along a helicoid surface, in the same way as a screw is turned into wood, and from the early stages when the tower leant to the northeast, up to the present time, the amount of this azimuthal rotation is $225^{\circ}$. The mean threshold, since the beginning of construction, based on a settlement of $2.5 \mathrm{~m}$ for a rotation from the northeast to the south thus becomes $2.50 \times 360^{\circ} / 225=4 \mathrm{~m}$.

It is known that every instantaneous movement in space is equivalent to a helicoidal movement and a translation; at present, the axis of this helicoidal movement passes through the instantaneous centre of rotation already referred to, with an axis at approximately $45^{\circ}$ to the east-west direction and to the vertical. The question can be posed as to why the leaning tower is still rotating eastwards; one is hesitant to refer to the Coriolis acceleration, of negligible magnitude $\left(4.4 \times 10^{-15} \mathrm{~g}\right.$ at the maximum speed of rotation in the past). Nevertheless, accumulated effects of a small Coriolis acceleration $\left(10^{-5} \mathrm{~g}\right)$ explain the rotation of the Foucault pendulum and one may wonder if, as in the case of the Pont de l'Alma (continuous action of the stream bringing a tilt), a structure with a very low safety factor is not influenced by sustained small forces acting over several centuries.

The Italians, by precise survey measurements in the Square of Miracles upon which the tower was built, have recently discovered a third type of rotation. Taking the Battistero tower (Fig. 17) as the reference point, they found that between 1968 and 1973, the north part of the square heaved and the south part subsided. The general speed of rotation of the square can be calculated to be about one half that of the tower. In addition, the level of the water table sank between 2 and $4 \mathrm{~m}$ between 1967 and 1974. It may be that these new factors could explain the acceleration of the rotation of the tower, but the dangerous feature is the inclination to the vertical and one cannot be very optimistic about the future fate of the tower, especially if no remedial measures are undertaken.

\section{Churches; eccentric lines of thrust}

Burano and Pisa are two examples where the resultant progressively increases in eccentricity. This section examines the case of buildings, which are also slender, but which have from the original time of construction an eccentric resultant applied to the soil. Cathedrals, be they Norman or Gothic, are a typical example. It is interesting to study how these buildings have behaved over the centuries and why some of them have collapsed. Is it the soil or the masonry that has betrayed the builder?

Norman architecture. Norman cathedrals gradually replaced the earlier churches, which were not as spacious and which were built with walls supporting timber roofs. These earlier structures frequently caught fire and the small roof spans limited the width of the nave. The most significant development of Norman architecture was to substitute stone vaults for the traditional roof, as a vault in stone is more favourable for, among other things, the resonance of ecclesiastical singing. In the earliest Norman churches, the nave is covered by a ceiling of barrel vaulting, semi-circular in section, sometimes reinforced and sometimes not, where the piers support the high lateral walls. The ambition of the mediaeval cathedral builders was for their naves to have the advantage of height, width and light. The buildings became progressively broader and higher and a maximum was achieved at Cluny III with $12.15 \mathrm{~m}$ between the centres of adjacent pilasters and $29.5 \mathrm{~m}$ from crown intrados to floor slab level. Monastic building was the most important type of construction at the time and the monastery of Cluny in Burgundy, led by a succession of very capable abbots, was one of the most influential institutions of the early Middle Ages. At its peak it had 1450 dependencies located in Portugal, Spain, England, Scotland, Germany, Switzerland, Italy and Palestine, as well as all over 


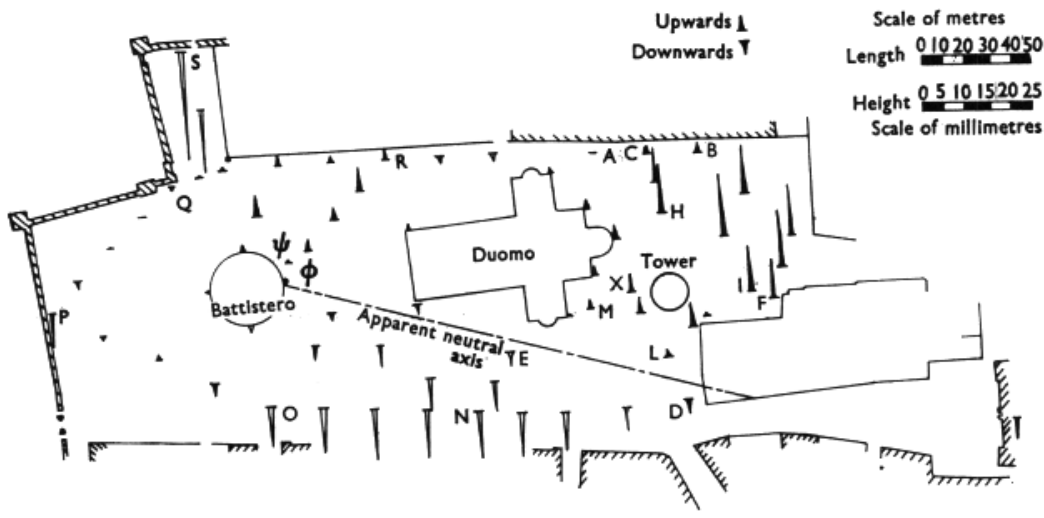

Fig. 17. Vertical soil movements between 1965 and 1973

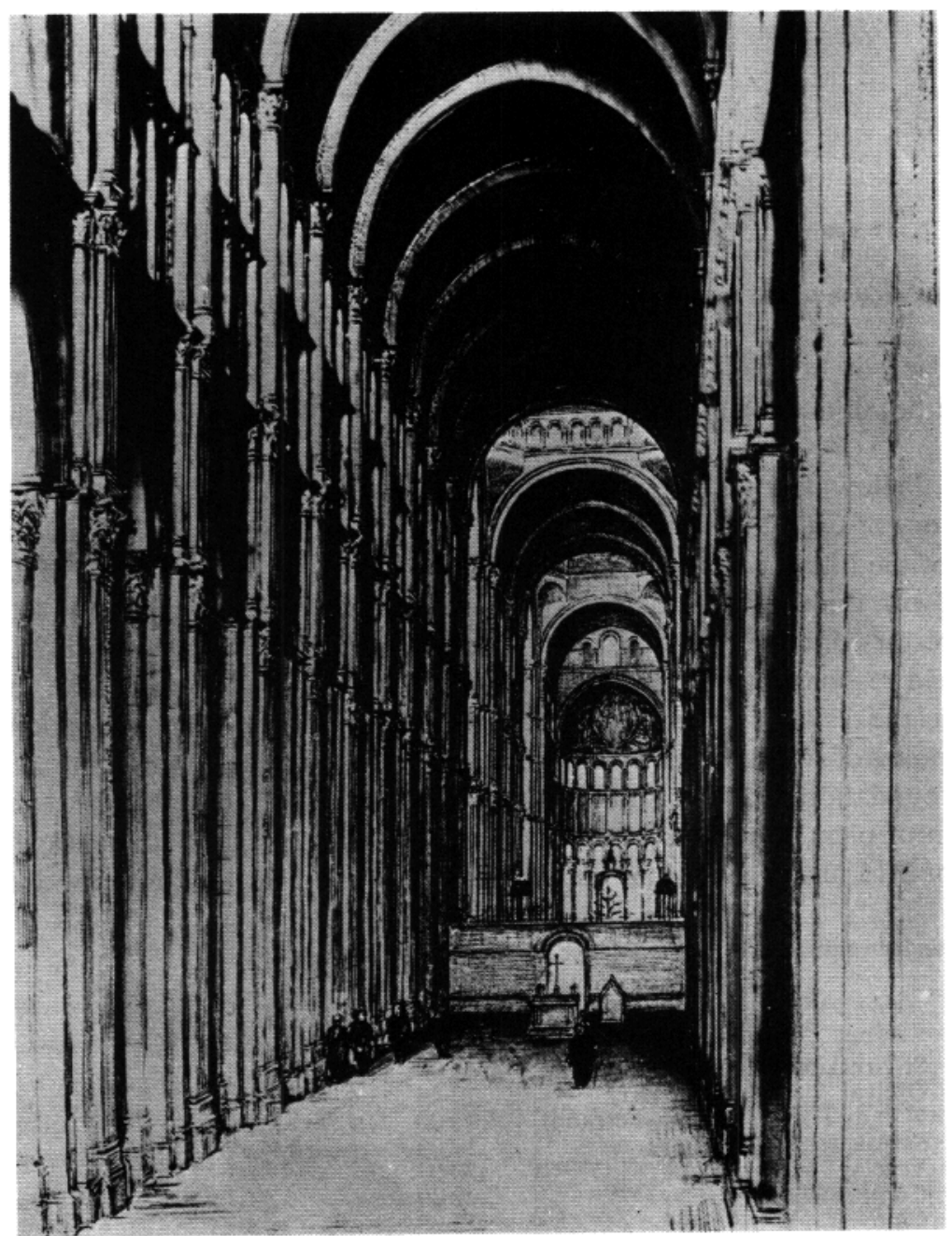

Courtesy K.J. Conant

Fig. 18. The Great Nave (after Bannister and Conant) 


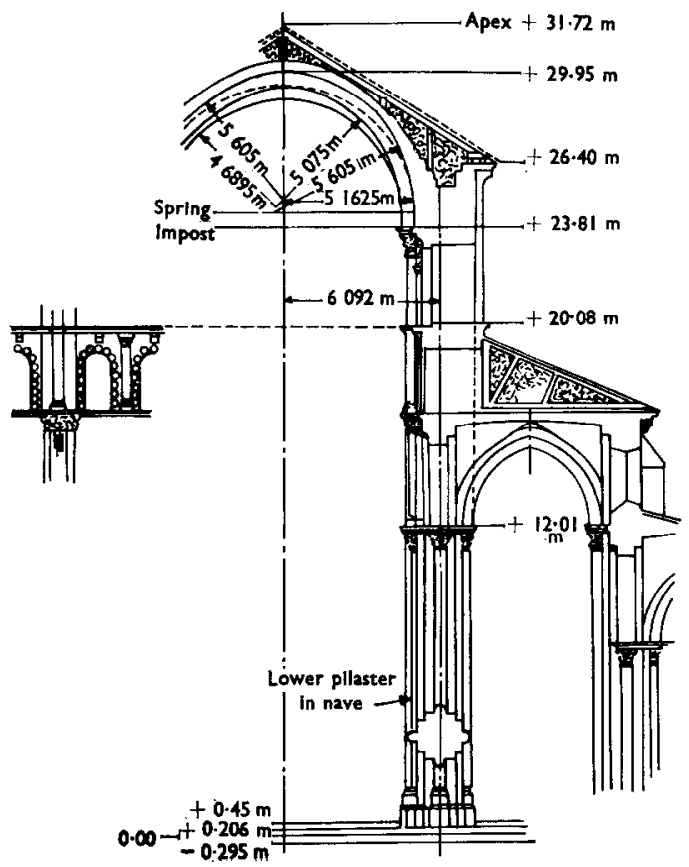

Fig. 19. Cluny III: semi-cross-section of the nave according to Conant

France. The high standard of building at Cluny affected the art over a wide area. The construction of Cluny III began in 1088 and was the unsurpassed masterpiece of the Norman style (Table 3 ).

Kenneth John Conant, Fellow of the Mediaeval Academy of America, has devoted a large part of his life to the history of Cluny III and is the author of an outstanding monograph on it. Fig. 18 is a drawing of the interior of the Great Nave, after Bannister and Conant. Fig. 19 is a transverse section with dimensions as deduced by Conant. As can be seen, above the triforium there was a clerestory of large open windows. However, this nave collapsed in 1125. Abbot Pons, who was held responsible died in prison in Rome in 1126. One might like to think that this collapse was the result of the wrath of God. Was it actually due to a foundation fault or to a misunderstanding of statics? As far as can be discerned, there is little to indicate that it was a fault in the foundation. At first, following the writings of Conant, it can be seen that the cruciform section of piers of section $3.20 \mathrm{~m}^{2}$ was supported on isolated foundations taken down to a depth of $3.15 \mathrm{~m}$ to the level of the gravel, which was also the groundwater

Table 3. Increase in height under vaulting in some noted Norman churches

\begin{tabular}{l|c}
\hline \multicolumn{1}{c|}{ Church } & Height, m \\
\hline St Nectaire & $15 \cdot 00$ \\
Orcival & $17 \cdot 40$ \\
N D du Port (Clermont-Ferrand) & $18 \cdot 00$ \\
St Austremoine (Issoire) & $19 \cdot 00$ \\
Vézelay & $20 \cdot 00$ \\
Compostelle & $22 \cdot 00$ \\
Cluny II & $13 \cdot 00$ \\
Cluny III & $29 \cdot 50$ \\
\hline
\end{tabular}




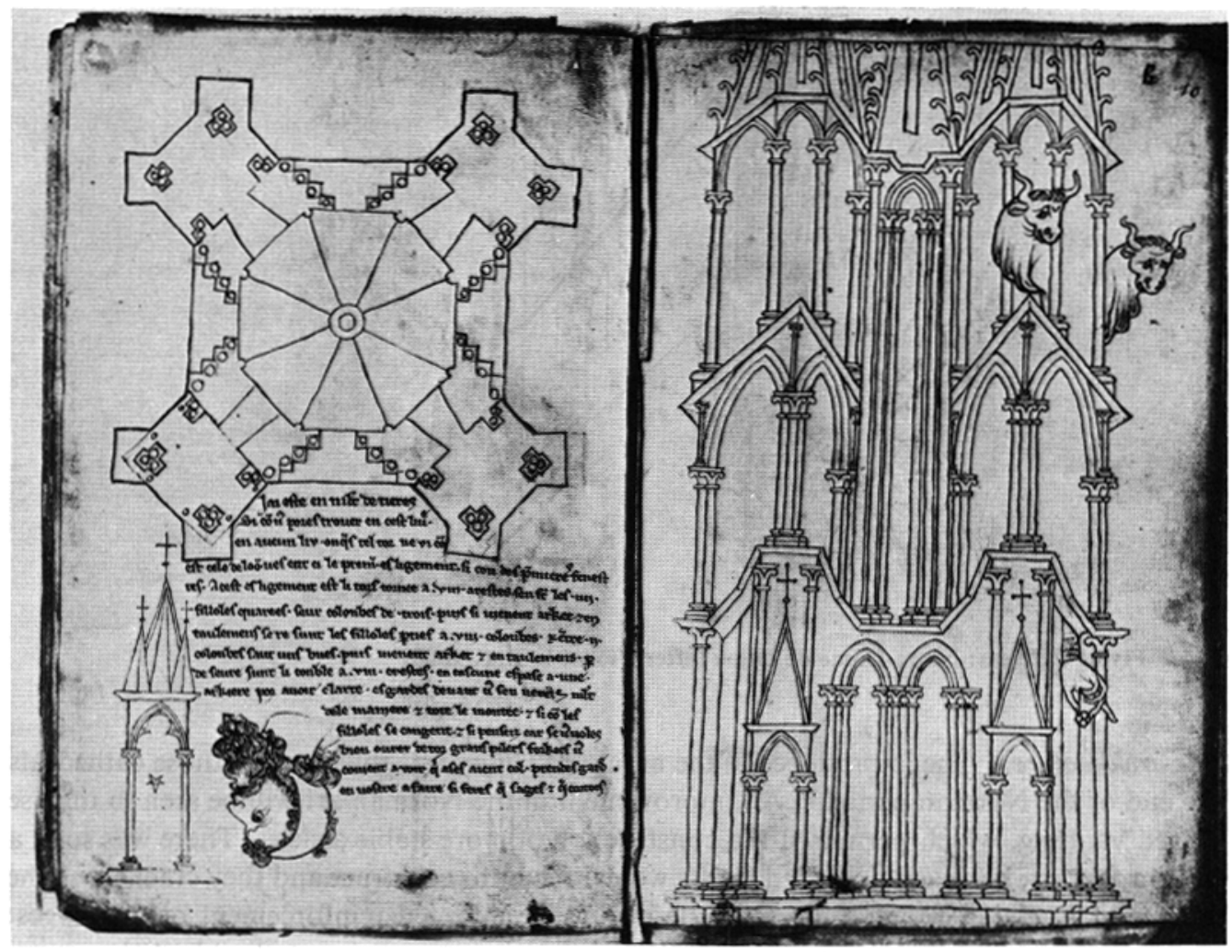

Courtesy Bibliothèque Nationale Française

Fig. 20. Laon Cathedral: sketch of foundations from Villard de Honnecourt (1325)

level. From a sketch prepared by Conant, it can be estimated that the section of the foundation was $9.0 \mathrm{~m}^{2}$ and that the stress on the soil was $700 \mathrm{kN} / \mathrm{m}^{2}$, which was acceptable. The individual foundations were linked by chain walls designed to prevent horizontal sliding of the foundation under the influence of the horizontal forces from the vaulting. This type of foundation can be found in many of the old early cathedrals, for example Charlieu and Laon ${ }^{9}$ (Fig. 20).

However, if on the one hand the foundations were not able to slip, they were unable on the other hand to provide a point of perfect fixity and to resist without rotating the large moments transmitted by the piers. At Cluny, as elsewhere (Charlieu), one finds in effect that the foundations were constructed in masonry, the facing of which proved to be of rather small stone in several beds of bound stone placed vertically with a high proportion of mortar, which we know would deform by virtue of its very slow setting time. This leads to the question of what moments were applied to the piers which leads us to examine some aspects of the equilibrium (see Appendix 2).

It is apparent that the collapse of Cluny was particularly due to an error in statics leading to the collapse of the high structure. The failure was compounded by the behaviour of the massive foundation, which was not able to achieve perfect fixity.

\footnotetext{
- Figure 20 shows Laon Cathedral and is taken from the album of designs of Villard de Honnecourt (1235). The drawings are working, rather than romantic, drawings, and this handbook, the only one of this period to have survived, is a veritable encyclopaedia not only of architecture but of the mechanics of the buildings. Fig. 20 is therefore a most ancient ground plan of a religious building.
} 


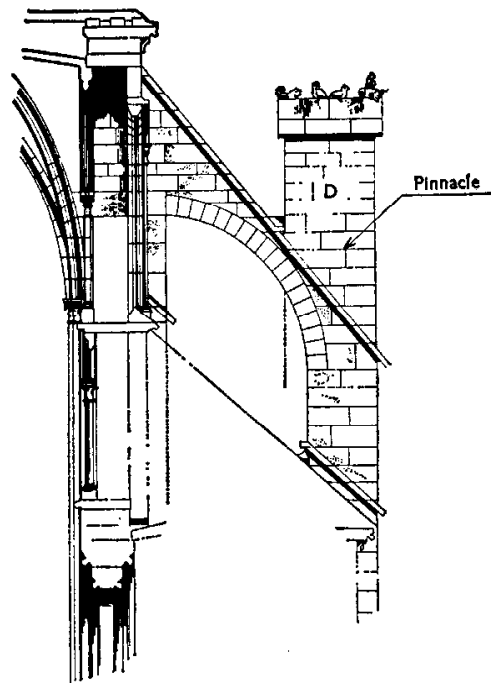

Fig. 21. Flying buttress: Notre-Dame de Dijon (after Viollet le Duc, 1868)

Gothic architecture. The imprudence of the monks at Cluny was thus fatal to those cathedrals of the end of the Norman period. An improvement in the Norman art will be seen in the use of ridged vaulting, which permitted the construction of more stable aisles. There was soon a decline in this art, however, as ridged vaults were difficult to construct and they cracked. The architects of England, Milan and of the Île de France adopted reinforcement of the ridges; they discovered at first that in constructing this bracing it was sufficient to build a light assembly of small stones or bricks to obtain a vault that was both strong and light. The diagonal circular arches and the double pointed arches transmitted their forces to points well fixed or supported by flying buttresses. The flying buttress, first used extensively at St Denis, became standard in construction. It permitted building to greater heights with a greater adaptability to soil conditions.

The flying buttress took the forces from the vaulting between springing and haunches, the pressures transmitted to the soil being lower and better centred; the builder, unless he is seeking excessive breadth, can adjust the weights and the positions of pinnacles in order to modify the

Table 4. Characteristics of vaults exceeding $30 \mathrm{~m}$ in height

\begin{tabular}{|c|c|c|c|c|c|c|}
\hline & 1 & 2 & 3 & 4 & 5 & 6 \\
\hline Place & $\begin{array}{c}\text { Date of start } \\
\text { of construc- } \\
\text { tion }\end{array}$ & $\begin{array}{l}\text { Number of earlier } \\
\text { buildings on same } \\
\text { site }\end{array}$ & $\begin{array}{l}\text { Height of } \\
\text { nave, } \mathrm{m}\end{array}$ & $\begin{array}{l}\text { Breadth of } \\
\text { nave, } m\end{array}$ & $\begin{array}{l}\text { Breadth of } \\
\text { arcade and } \\
\text { aisles, } m\end{array}$ & $\frac{\text { Col. } 3}{\text { Col. } 5}$ \\
\hline $\begin{array}{l}\text { St Denis } \\
\text { Notre Dame } \\
\quad \text { de Paris } \\
\text { Bourges } \\
\text { Chartres } \\
\text { Reims } \\
\text { Amiens } \\
\text { Beauvais }\end{array}$ & $\begin{array}{l}1136 \\
1163 \\
1185 \\
1194 \\
1211 \\
1220 \\
1247\end{array}$ & $\begin{array}{c}5 \\
3 \\
1 \\
5 \\
\text { numerous } \\
1 \\
2\end{array}$ & $\begin{array}{l}29 \cdot 0 \\
\\
34 \cdot 0 \\
37 \cdot 0 \\
37 \cdot 0 \\
38 \cdot 0 \\
42 \cdot 3 \\
48 \cdot 0\end{array}$ & $\begin{array}{l}12 \cdot 5 \\
12 \cdot 0 \\
14 \cdot 0 \\
16 \cdot 0 \\
16 \cdot 0 \\
14 \cdot 0\end{array}$ & $\begin{array}{l}39(1)^{*} \\
46(2)^{*} \\
41(2)^{*} \\
30(1)^{*} \\
50 \\
40\end{array}$ & $\begin{array}{l}0.74 \\
0.74 \\
0.90 \\
1.23 \\
0.76 \\
1.06\end{array}$ \\
\hline
\end{tabular}

* The number in parentheses represents the number of aisles on each side of the nave. 


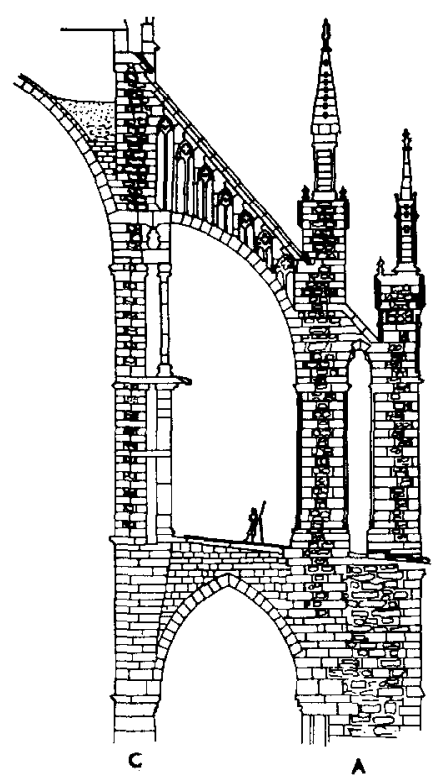

Fig. 22. Flying buttress: Amiens Cathedral (after Viollet le Duc, 1868)

line of the resultant as at Notre Dame de Dijon (Fig. 21). In this church the heavy pinnacle $\mathrm{D}$ is eccentric towards the nave, redressing the stresses at the same time as loading the haunches, causing them to open up at their extrados. If there is something even more remarkable in Gothic art, it is the prestressing that the builder was able voluntarily to induce in the structure, starting from the foundations, well before the formal introduction of this technique. Fig. 22 shows the transverse section through the nave of the cathedral at Amiens. Settlement of the piers $C$ would not have been dangerous if the piers $A$ had settled less. In the case of differential settlement in regard to $A$, there would be the effect of taking advantage of the flying buttress against the haunches of the high vaulting and to raise the pressure to an intermediate state between the two limiting Coulomb values. This effect is obtained as a consequence of making the foundations of A very solid and raising the piers $C$ with joints filled with mortar, piers $A$, in contrast, being composed of monolithic stone columns of considerable length.

St Denis (1136), sepulchre of the kings of France, is the first church where the flying buttress was adopted as a method of construction. The nave is $38 \mathrm{~m}$ high beneath the vaulting and is $12 \mathrm{~m}$ in breadth. This cathedral is the point of departure for a whole series of Gothic cathedrals.

Principal characteristics of vaults that exceed $30 \mathrm{~m}$ in height are given in Table 4. It is seen that, at those places where monasteries had been established over a long period (six successive churches at Chartres), it was possible to construct higher and higher on soil that had been partially consolidated. As is shown in column 6 of Table 4, Chartres with its single aisle and a ratio of 1.23 already represented a certain audacity; but the apogee of vertical Gothic is Beauvais, with its height of $48 \mathrm{~m}$, which ended through an accidental collapse in 1284 , twelve years after its attainment. The circumstances of the collapse of 1284 were the subject of a paper by Heyman (1967). The explanation given in that paper is essentially the same as that given by Viollet le Duc (1868). The failure involved the chancel; the transept and the aisle had not been constructed; the nave was never to be built. The excavations made during the 


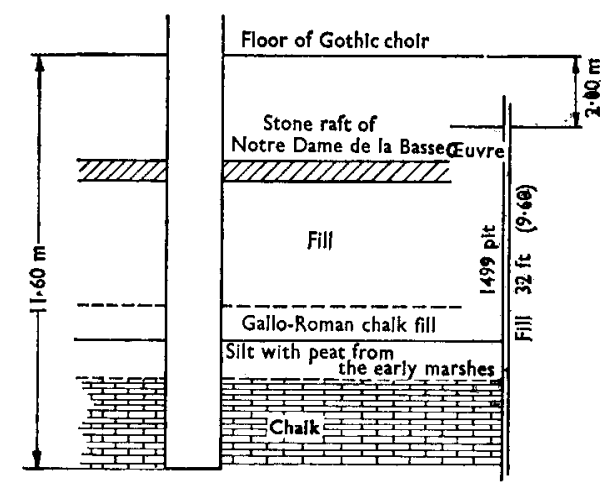

Fig. 23. Beaurais: foundation of the Gothic choir

past ten years by the archaeologist, Chami (1975), leave little doubt that there was a foundation failure. There were, in the same place, the remains of an old Carolingian cathedral, called Notre Dame de la Basse Euvre, with sub-basement at $3.00 \mathrm{~m}$ below that of the church of 1274 (Fig. 23). The foundations of the Gothic chancel went down below the lower basement of the old Carolingian church, into $5 \mathrm{~m}$ of rubble and chalk fill which dates from the Gallo-roman period and was found widespread on the old marshes. This is confirmed by the archives which show that trial pits were excavated in 1499 (when Martin Chambiges built the transept); this places the lower foundations of the Gothic chancel at $11.60 \mathrm{~m}$ on the natural chalk below the level of the compressible old marshes. Onc can admire the clcar-sightedness of the builder in 1274 in taking the church foundation below the level of the compressible marshes.

The accident is believed to be due to the use of mediocre stone, which deformed plastically following a process that is interesting to relate because it illustrates well the transfer of loads that occurs in piers of unequal dimensions supporting the masonry, leading to overworking and collapse of the ceiling. Fig. 24 represents the section through the choir (Viollet le Duc, 1868). The architect had used a double flying buttress; the intermediate pier, $O$, is judiciously wedged towards the nave relative to $P$, so as to counteract the reversal of bending moment. Benouville (1891) calculated the horizontal pressures transmitted in total by the two flying buttresses (axial pier spacing $9 \mathrm{~m}$ ) to be of the order of $30 \mathrm{tf}$ which by virtue of the weight of piers $\mathrm{O}$ and $Q$ gives rise to resultant that is very well centred. However, the piers $E$, which adjoin the nave, are thick at the base, but divide into the pillar $\mathrm{A}$ and two small shackled columns $\mathrm{L}$, as shown in section 1-1, the whole assembly being capped by the lintel $\mathrm{M}$. The collapse was due to the shallowness and slenderness of these small columns, which have few joints and are thus relatively stiffer.

The pillar A was constructed with a good masonry casing having a rubble core with a high percentage of mortar. As in the masonry lining of tunnels, all the forces are transferred to the outer dressed masonry. After the mortar had cemented, the whole of A did not have the same modulus of compression as the small column $\mathrm{L}$ and began to deform in accordance with the lining of pillar A, which is subject to eccentric loading. A collapse mechanism develops inexorably (see Vironnaud and Chassaing (1959) and Paquet (1936)). This accident shows the danger of counting on a structural support comprising parallel flexible members of different moduli of deformation (pillars of stone to support the roof of a mine, or struts in open cuts). Afterwards, the three great arcades above the altar were reinforced by the addition of an intermediate pier, the flying buttresses increased in number and the abutments reinforced. 
Fig. 24. Beauvais: crosssection of the Gothic choir (after Viollet le Duc, 1868)
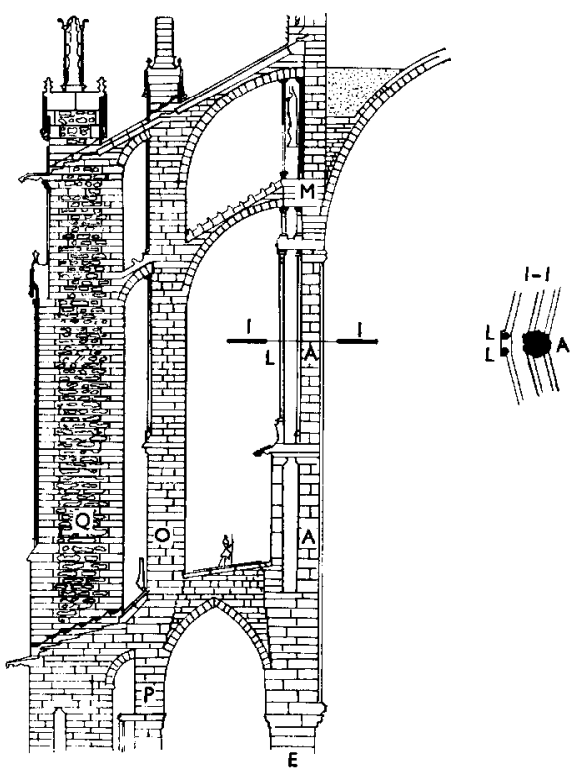

However, the 100 Years War prevented the continuation of the work. In 1550, the transept was completed, but in place of the construction of the nave it was decided to build the crossing of the transept as a tower topped by a mansard roof, at a height of $153 \mathrm{~m}$. As it would have been the nave that would have reacted against the forces, in 1573 the pillars yielded progressively and leant over testing the deformability of the mortar and the stone of the pillars. Cluny III, with its $29.5 \mathrm{~m}$ and Beauvais, with its $48 \mathrm{~m}$ represent peaks of Norman and Gothic architecture respectively, but in neither case was the collapse due to the foundation work.

It should not be concluded, however, that our ancestors possessed a fundamental knowledge of soil mechanics. In fact, mediaeval architecture was largely empirical. The ancient buildings seen today are those that have survived. Quicherat says 'Nothing is more common than to find that churches built in the eleventh century fell soon after their building, or by the end of the century'. Of the great church towers built in England during the Norman period, a considerable proportion collapsed sooner or later, and often sooncr. There are constant references to the fall of buildings due to insufficient foundations.

In 985, the tower of Romsey Abbey, which had hardly been completed ten years, developed such alarming cracks that it had to be taken down and rebuilt on better foundations (Chron. Abb. Ramesiensis, 87-8). At Gloucester, the west tower fell about the end of the eleventh century 'through default of the foundations'. Failure of the foundations seems also to have been the cause of the fall of the west tower of Worcester in 1175. Records in texts and chronicles of other collapses are rare. Nevertheless, in the miracles of St Benoit, the vaulted transept of a priory at Perrecy les Forges is described: 'the inadequacies of the bearing provoked early in its life the collapse of the northern part'- 'pars maxima testudinis lapideae ipsius ecclesiae Patriciaci ... a parte aquilonali'. Towards 1095, the monks reinforced the piers of this northern part-'ut eadem testudo robustiori superposita fundamento firmior foret'. This is a rare Latin text that deals with the question of reinforcing the foundations.

There were also those cathedrals that we know became deformed by virtue of insufficient strength in their foundations. Examples of such are Chapaize (Saône-et-Loire), a Norman church where the enormous pillars punched into the clay and rotated to a slope of $1 / 10$ towards the exterior, leading to the fall of the vault of the nave (Fig. 25); Dozouls (Aveyron) and 


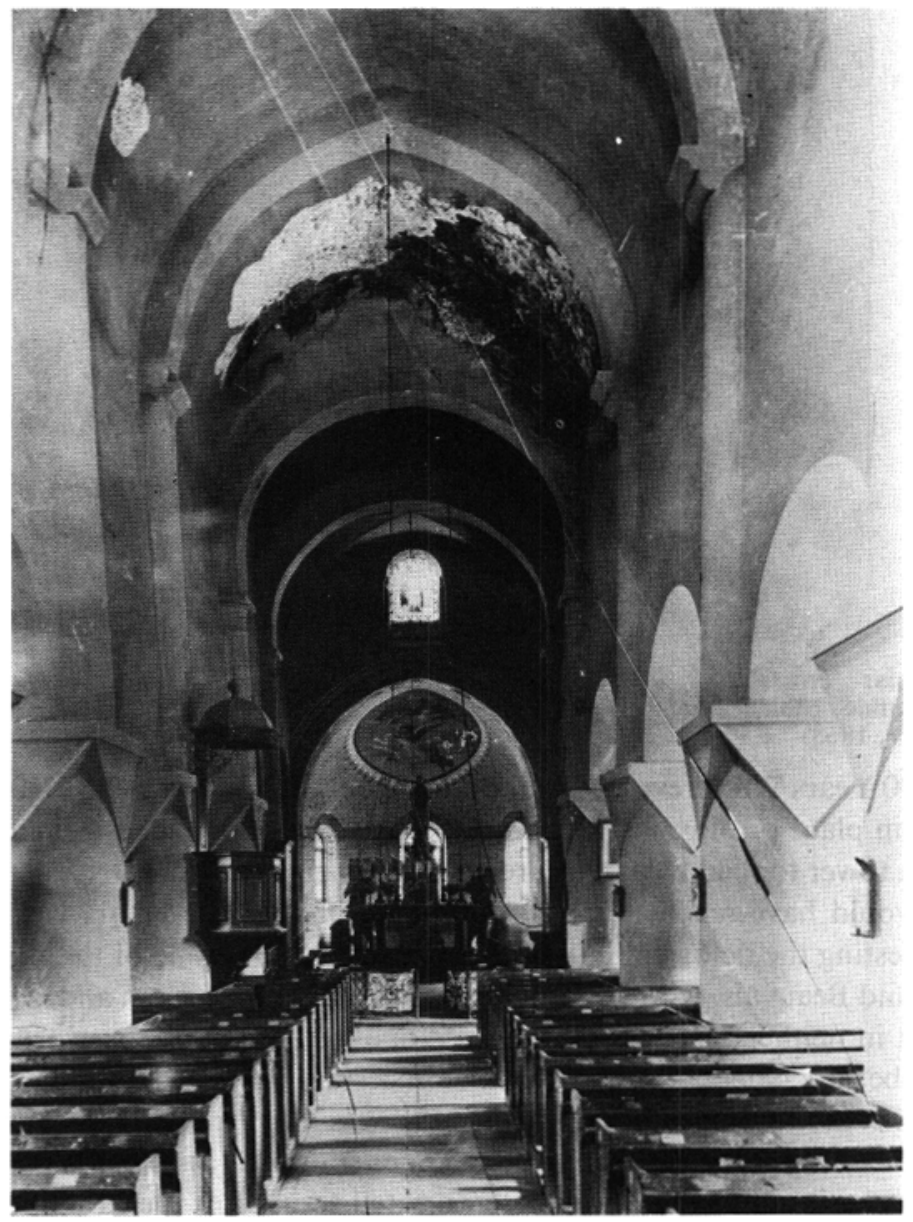

Fig. 25. Chapaize: interior of nave

Sagnat (Creuse) where, because of the small width of the aisles, considerable deformation of the walls towards the exterior can be observed. An example in England is Fountains Abbey (Yorkshire), where the piers bowed outwards to such an extent that the arches and vault fell through; but most curious of all is that of Santa María la Real del Sar at Santiago de Compostela (Spain) (Figs 26-27). The tilt of the pillars, according to Jimenez Salas (1975), is due to the presence of boggy lenses below the foundations, and the lowering of the water table.

Perhaps the mediaeval builder unconsciously defied the soil and delighted in a difficult game that consisted of making up a pyramid to the point shown in the example in St Sauveur-deLeyre (Fig. 28), an ancient Benedictine monastery. Supporting the whole weight of the high church, the three vaults that supported the nave and the two aisles were in turn carried on heavy piers, abruptly terminated at a depth of several decimetres below ground level, where they picked up the even smaller and very short columns, capped with splayed overhanging capitals.

Generally, the Romans always built their structures in good ground conditions, using heavy masonry accompanied by excellent mortar. The construction was rigid, with rigid foundations, by virtue of the quality of the mortar, the choice of the soil and the excellence of the 


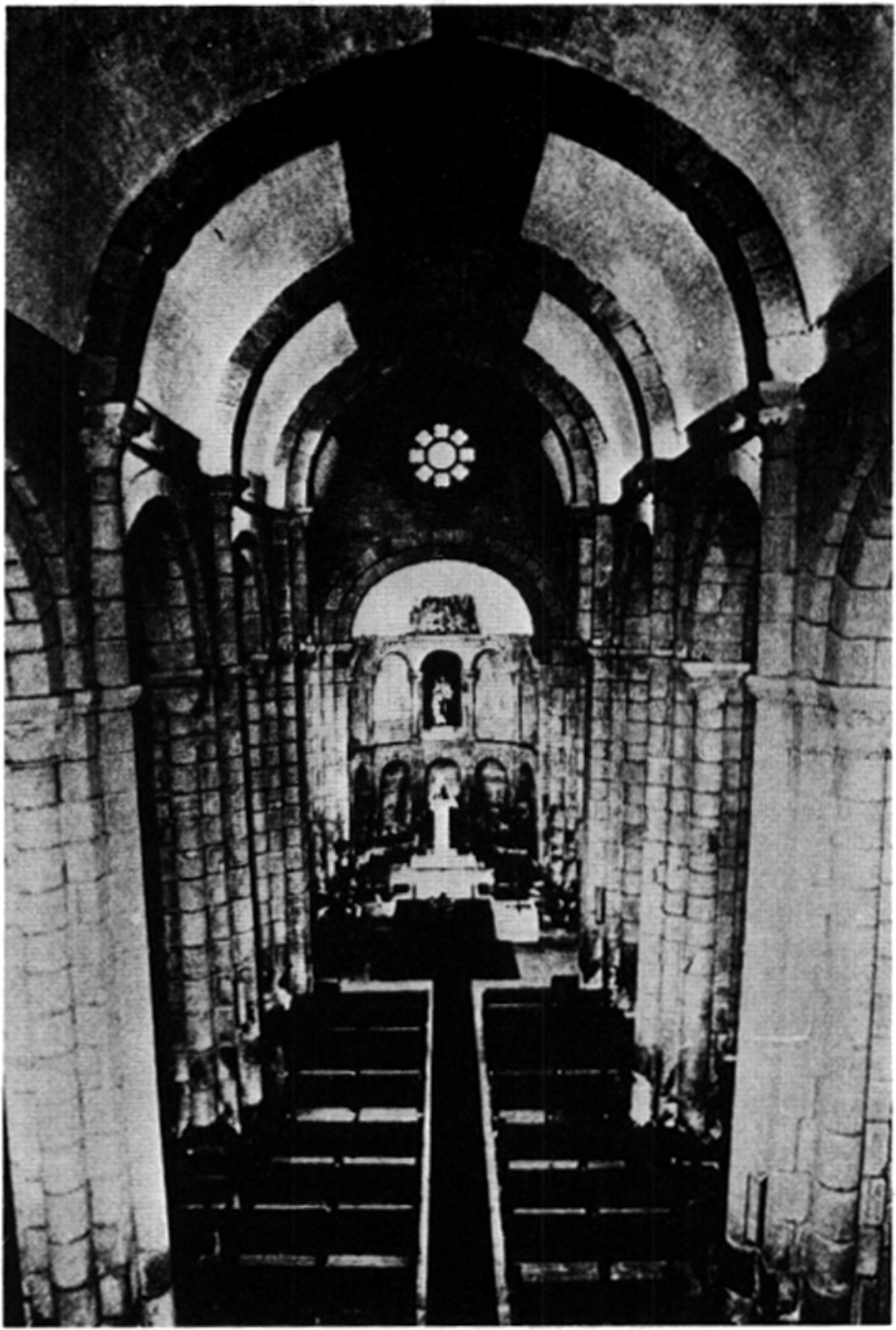

Fig. 26. Santa María la Real del Sar: nave

masonry. During the Norman period, however, cathedrals were badly founded for several reasons: the siting of the church depended little on the quality of the soil; it was not known how to dress the limestone; the foundations were made pell-mell in an abundance of mortar. There were therefore several collapses. The impression is one of zeal of the bishops to build and rivalry between the monasteries, which did not necessarily correspond to their often mediocre financial resources. It was therefore held to be unnecessary to spend a great deal below the surface of the soil. It is this that explains why the great cathedrals, such as at Troyes, Châlons on the Marne, Sées and Meaux are badly founded. During the Gothic period, there was a reaction against this negligence; the main structure was of ashlar masonry, which was better quality and of better cut blocks in a good mortar; the foundations were more adequate, and with the grace of the flying buttress the forces were better directed and centred on the foundations. 


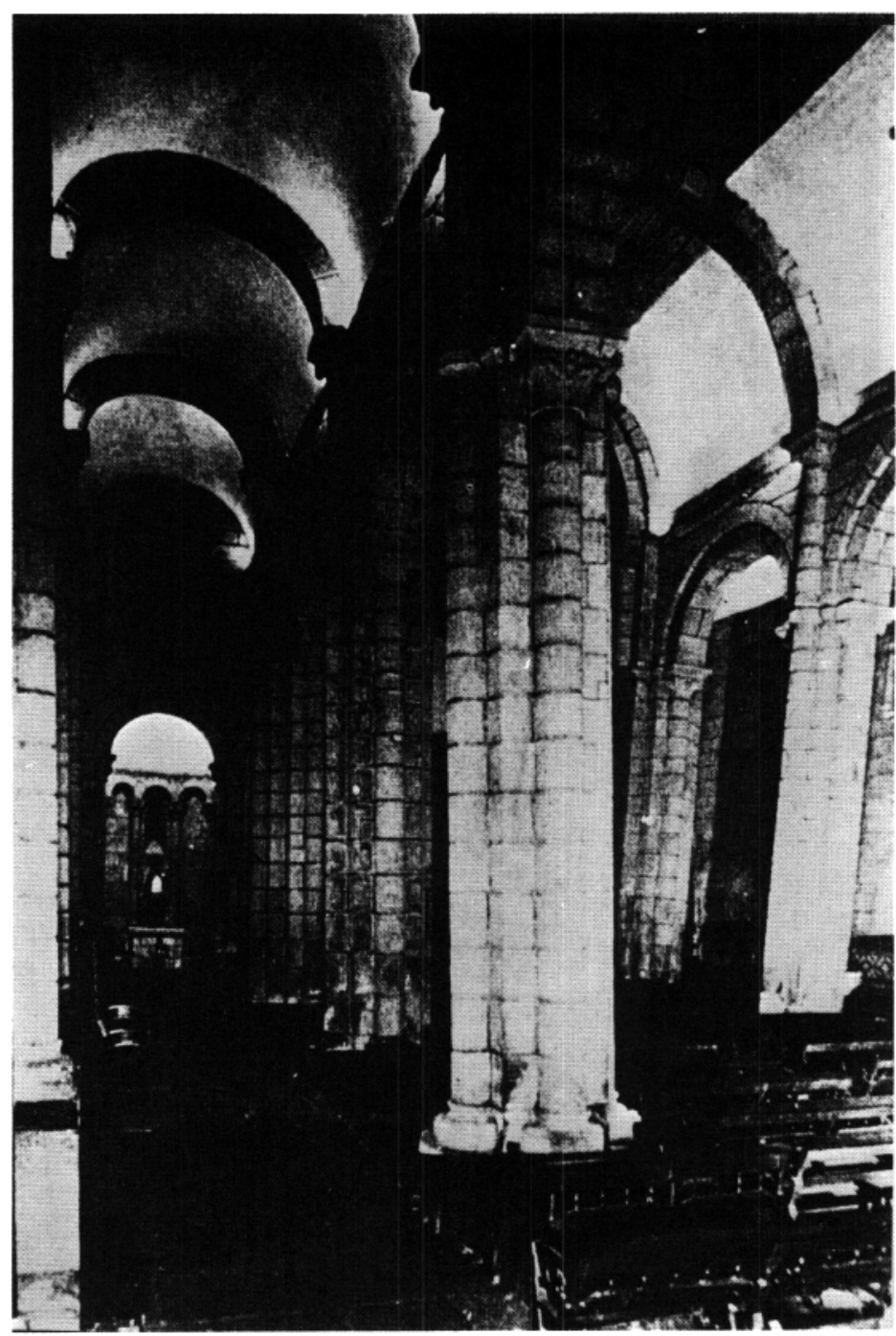

Fig. 27. Santa María la Real del Sar: arcade

\section{Old superstructures with bad distribution of load}

Theoretical considerations. When one compares the settlements of a semi-infinite homogeneous isotropic and elastic foundation of circular, square, rectangular shape and so on, it is found that at least to an accuracy of $8 \%$, they can be represented by a single formula (Fig. 29). It is therefore not only the pressure that governs the settlement, but also the product $q R_{\mathrm{H}}$, or again the weight inside the perimeter $W / P$. To make a first assessment of the settlement, a certain sequence of usual values of perimeter loads categorized by structure may be considered, taking into account their ranges of weight and the usual pressures (Table 5).

With the aid of formulae (i) and (ii) in Fig. 29, the order of settlement can be calculated. Conversely, knowing the observed settlement, a kind of equivalent modulus of the soil can be deduced by formula (iii): $E=3 \cdot 5 q R_{\mathrm{H}} / \rho$. This notion of the forces inside the perimeter is 


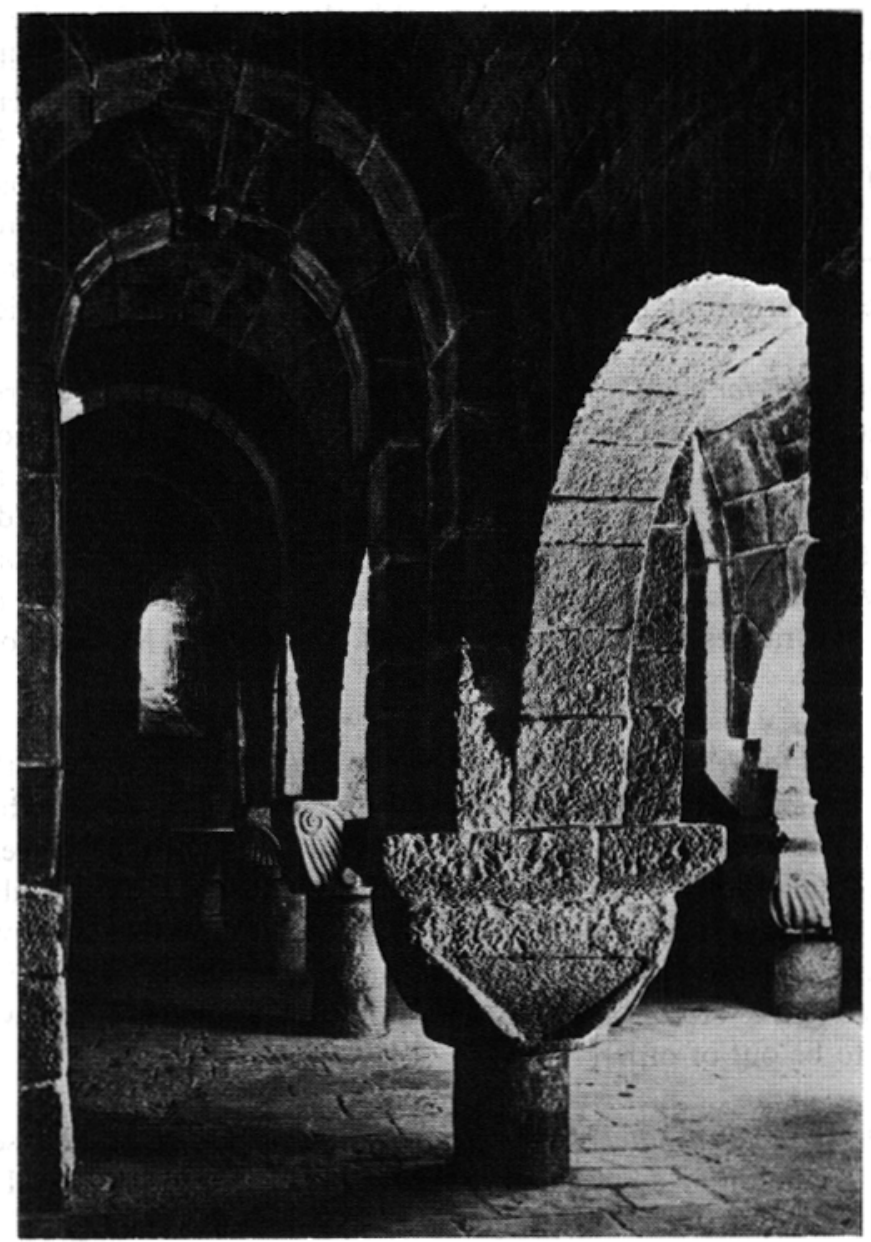

Fig. 28. St Sauveur-de-Leyre: interior

(i) $\rho=3.5 \frac{q R \mathrm{R}}{E}$ or (ii) $\rho=\frac{3.5}{E} \frac{W}{P}$

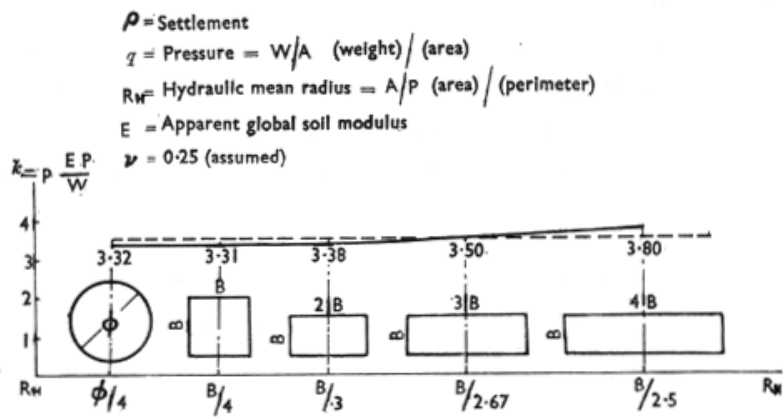

For $k=3.5$ error $<8 \%$ for majority of cases irrespective of form of foundation

Fig. 29. Rigid foundation on infinite isotropic half-space 
theoretically applicable only to soils that are homogeneous in depth, but these rarely occur. It is also applicable to soils of the same geological background, of which the mechanical properties change linearly with depth; these occur frequently and may be called quasi-homogeneous soils. It is therefore found that with constant $q$, the settlement increases somewhat more rapidly than $R_{\mathrm{H}}$ or, conversely, that $E$ deduced from the settlement is a little higher for foundations of large diameter, taking into account the mean modulus, than for those that are founded somewhat deeper (Table 6). Formulae (i), (ii) and (iii), which are the same thing presented in different ways, enable the facts to be reassembled in isolation and lead to several subsequent syntheses permitting better appreciation of the behaviour of ancient structures.

Characteristic values of E for quasi-homogeneous soils. Table 6 was derived from the contributions to the recent conference at Cambridge relating to foundations on rafts founded on quasihomogeneous soils. It gives as a function of the typical types of soil the apparent moduli ranged in decreasing order. The settlements are the final figure, observed or deduced from the settlement curve; they represent the variation of level of the plan of the foundation, taking into account any heave that has occurred. It can be seen that the apparent modulus for the different types of soil ranges from $2 \cdot 3$, for soft soil, to over $450 \mathrm{MN} / \mathrm{m}^{2}$ for those that are very much stiffer.

Increase of $E$ with $R_{\mathrm{H}}$ for a given quasi-homogeneous soil. With regard to the increase of $E$ with mean radius, it is interesting to analyse the seven examples given by Breth and Chambosse (1974c) for various high buildings founded on Frankfurt clay. Table 7 gives the dimensions of the rafts of the foundations, which are listed in order of the mean hydraulic radius. With the exception of building 7, which is an isolated case, it is found that the apparent modulus, which takes into account the final settlement, lies in the zone $24-42 \mathrm{MN} / \mathrm{m}^{2}$, when the mean radius lies in the zone $5.5-11 \mathrm{~m}$. The hypothesis of a linear increase in $E$ with $R_{\mathrm{H}}$ does not, therefore, appear to be out of order.

Decrease of $E$ with the factor of safety; old superstructures. In the case analysed for the Frankfurt clay (Table 7), minimum $c_{\mathrm{u}}$ measured in unconfined compression is $150 \mathrm{kN} / \mathrm{m}^{2}$. The limiting pressure is theoretically in the neighbourhood of $5 \times 150=750 \mathrm{kN} / \mathrm{m}^{2}$, which compares with the net applicd stress between $75 \mathrm{kN} / \mathrm{m}^{2}$ and $210 \mathrm{kN} / \mathrm{m}^{2}$, which assurcs a very high factor of safety.

To see how $E$ diminishes with the factor of safety, three bridges, Chelsea, Waterloo and Rennie's London Bridge, all three founded on the London Clay, serve as an example (Table 8). The apparent modulus of elasticity of Rennie's bridge is only one-third of that at Chelsea, by virtue of the low factor of safety for its foundation. Returning to old structures, and considering Rennie's bridge $\left(2480 \mathrm{kN} / \mathrm{m}\right.$ and $\left.611 \mathrm{kN} / \mathrm{m}^{2}\right)$, the Pont de l'Alma $(2000 \mathrm{kN} / \mathrm{m}$ and $\left.533 \mathrm{kN} / \mathrm{m}^{2}\right)$ and the Tower of Pisa $\left(2500 \mathrm{kN} / \mathrm{m}\right.$ and $\left.480 \mathrm{kN} / \mathrm{m}^{2}\right)$ the perimeter loads and the pressures are seen to be very important. The perimeter loads today take advantage not only of

Table 5

\begin{tabular}{l|c|c|c|c|c|c}
\hline Type of structure & $\begin{array}{c}\text { Buildings less } \\
\text { than 10 } \\
\text { storeys }\end{array}$ & $\begin{array}{c}\text { Buildings } \\
10-60 \\
\text { storeys }\end{array}$ & Oil tanks & Silos & $\begin{array}{c}\text { Blast } \\
\text { furnaces }\end{array}$ & $\begin{array}{c}\text { Nuclear } \\
\text { reactors }\end{array}$ \\
\hline $\begin{array}{c}\text { Typical range of } W / P, \\
\mathrm{kN} / \mathrm{m}\end{array}$ & $0-400$ & $400-2500$ & $250-3000$ & $500-2000$ & $1500-3000$ & $3000-6000$ \\
\hline
\end{tabular}




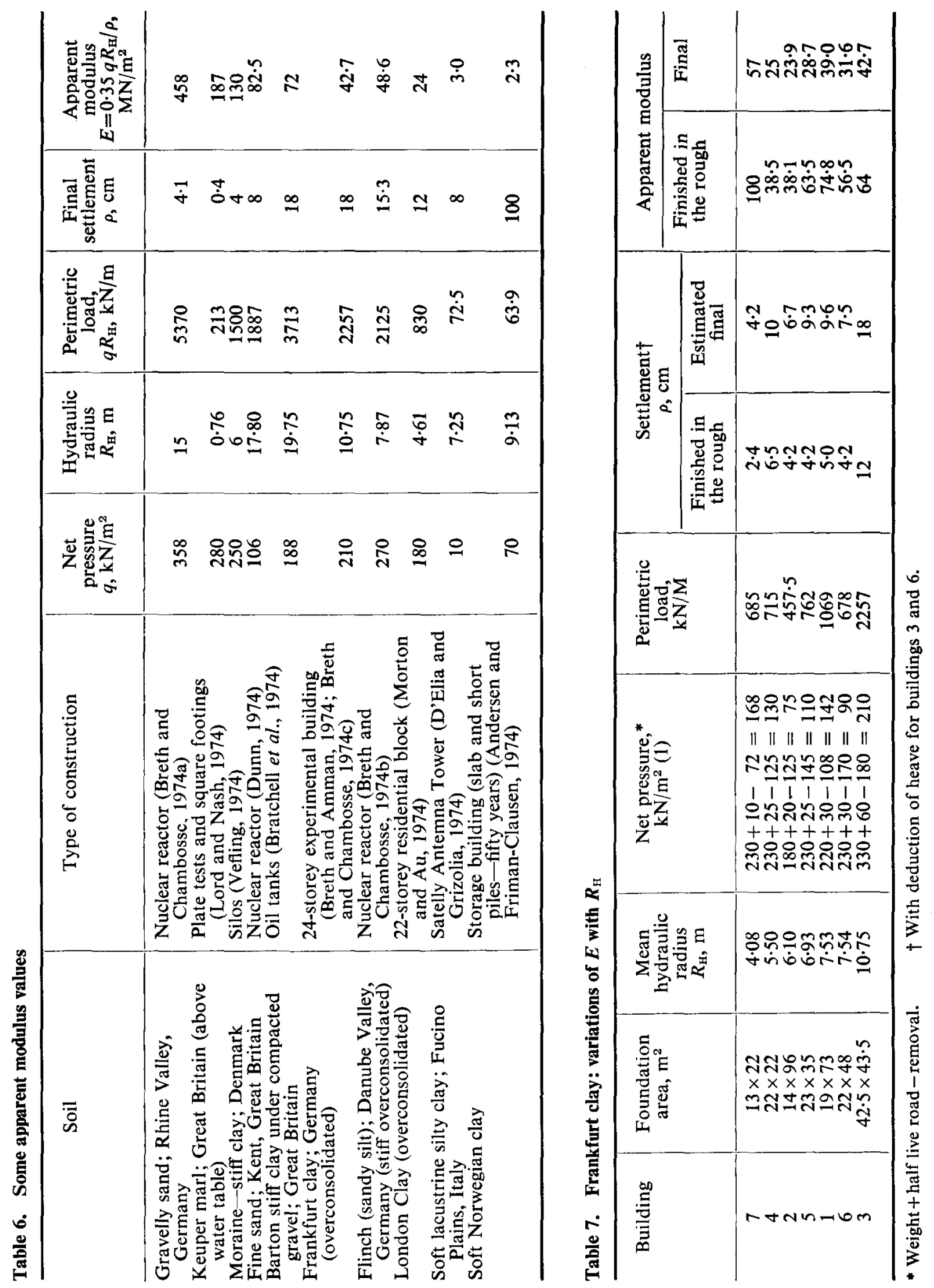



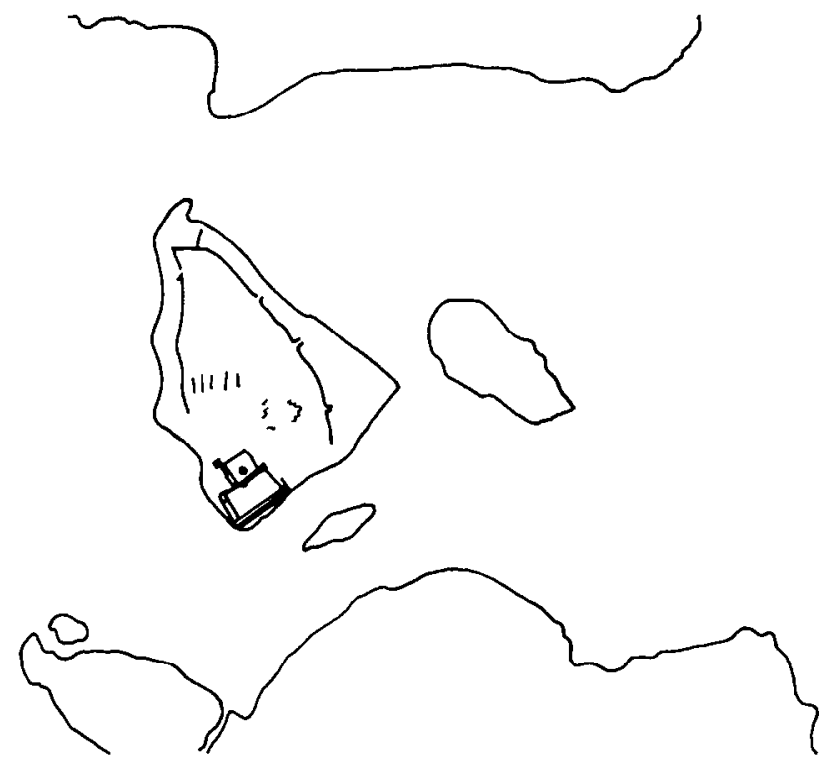

Fig. 30. Ancient island

a better knowledge of the behaviour of the soils, but also of the progress of technology, which allows lightening of the soil to the future level of the foundation by excavation, and the use of oversized slabs, thus reducing the net applied pressure. For ancient buildings founded on mediocre soil at depth, the error of the builders was frequently in having considered a working stress independent of the perimetric loads such that in time differential settlement occurred and hinges formed around the perimeters of heavily loaded areas; it is therefore often in the domes of churches, of towers, of cathedrals, of castle dungeons and of the peristyles of palaces that these hinges are seen. A typical example in Paris is the Grand Palace, of which the peristyle, forming a very important mass inside the perimeter, has become detached from the rest of the palace. Many of the English cathedrals have suffered from foundation trouble especially under the heavy central towers that were a special feature of Norman building.

An outstanding study of this phenomenon (Dowrick and Beckman, 1971) in York Minster shows the differential settlements $(23 \mathrm{~cm})$ and distortion between the successive towers and the surrounding structure. The vertical load on each of the four main piers of the central tower was $38 \mathrm{MN}$ (corresponding to a $1200 \mathrm{kN} / \mathrm{m}$ perimetric load at their foundations) whilst the normal arcade columns in the nave and choir carried about $3 \mathrm{MN}$. A further example is the Ottawa National Museum in which the massive entrance porch has suffered a differential settlement; it pulled away from the rest of the building and had to be removed.

Table 8

\begin{tabular}{|c|c|c|c|c|c|c|c|c|}
\hline Bridge & Dates & $\begin{array}{l}\text { Foundation } \\
\text { size, } \mathrm{m}\end{array}$ & $\begin{array}{c}\text { Hydraulic } \\
\text { radius } \\
R_{\mathrm{H}}, \mathrm{m}\end{array}$ & $\begin{array}{c}\text { Applied } \\
\text { pressure } \\
q, \mathrm{kN} / \mathrm{m}^{2}\end{array}$ & $\begin{array}{l}\text { Safety } \\
\text { factor } \\
5 c_{\mathrm{u}} / q\end{array}$ & $\begin{array}{l}\text { Perimetric } \\
\text { load, } \\
\mathrm{kN} / \mathrm{m}\end{array}$ & $\begin{array}{l}\text { Final } \\
\text { settle- } \\
\text { ment } \\
\rho, \mathrm{cm}\end{array}$ & $\begin{array}{l}\text { Apparent } \\
\text { modulus, } \\
\mathrm{MN} / \mathrm{m}^{2}\end{array}$ \\
\hline $\begin{array}{l}\text { Chelsea } \\
\text { Waterloo } \\
\text { London }\end{array}$ & $\begin{array}{l}\text { Built } 1936 \\
\text { Built } 1938 \\
1830-1961\end{array}$ & $\begin{array}{c}8.5 \times 32 \\
8.25 \times 35 \cdot 6 \\
11 \times 31.2\end{array}$ & $\begin{array}{l}3.36 \\
3.35 \\
4 \cdot 06\end{array}$ & $\begin{array}{l}184 \\
289 \\
611\end{array}$ & $\begin{array}{l}4 \cdot 35 \\
2 \cdot 7 \\
1 \cdot 3\end{array}$ & $\begin{array}{r}617 \\
968 \\
2480\end{array}$ & $\begin{array}{r}5 \\
10 \\
60\end{array}$ & $\begin{array}{l}43 \cdot 2 \\
33 \cdot 9 \\
14 \cdot 5\end{array}$ \\
\hline
\end{tabular}




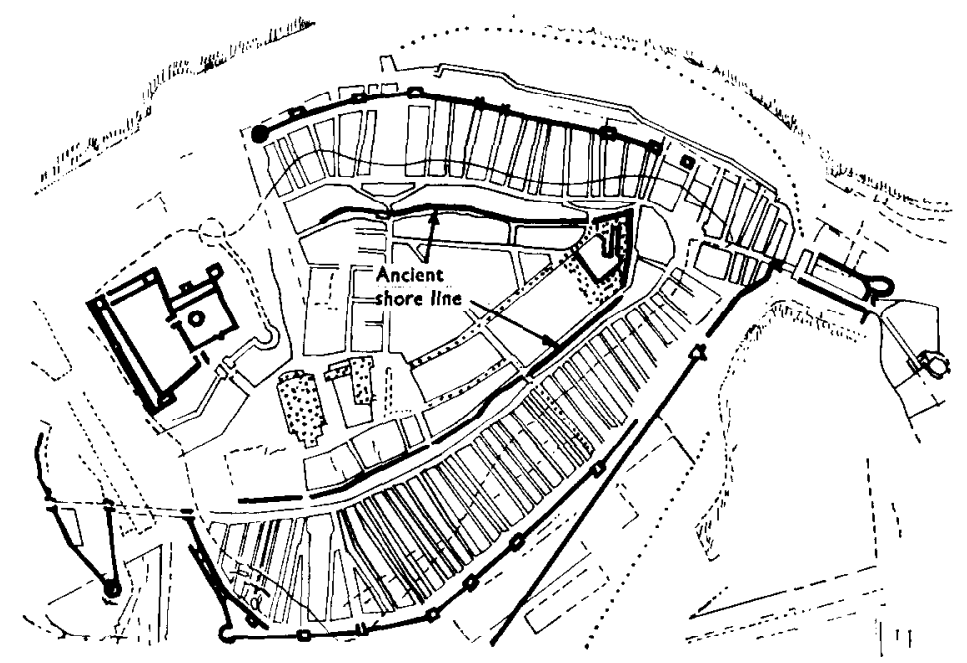

Fig. 31. New Island

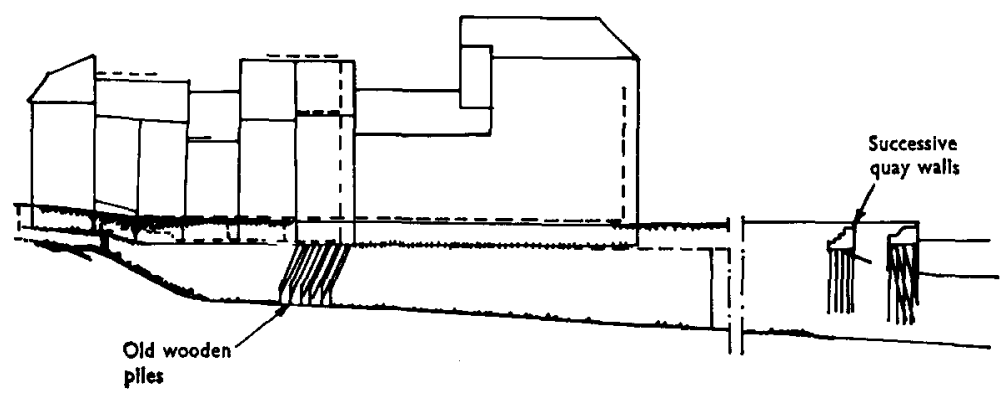

Fig. 32. Vertical cross-section

\section{Old structures on sloping sites}

A very good example of building settlement and distortion over a long period can be seen in Old Stockholm. The old city was built in the thirteenth century on a hilly island now called Gamla Stan (old town), at the north end of which was later built the Royal Palace. Fig. 30 shows a reconstruction of the island as it was at the end of the thirteenth century; today, the island is far larger (Fig. 31). The enlargement of the island is explained first by the general emergence of the Scandinavian continent (at a rate of $40 \mathrm{~cm}$ per century), due to the melting of glaciers and snows causing the phenomenon of isostatic uplift and the European coasts from Poland to Spain to sink. Second, especially during the Middle Ages and Sweden's period of greatness, from 1611 to 1715 , there was an urgent need to enlarge Stockholm, so that layers of refuse (gravel, organic matter, wood chips, ashes, and so on) were spread over the shore; these nowadays are exerting a thrust on the more recent quay walls. The island core is formed of gravels, overlain on the northern side by thin clay layers; the fill overlying these formations takes the shape of a wedge (Fig. 31). The buildings on the left of Fig. 32 are, of course, the more ancient; they were founded on gravel. The buildings to the right, on the fill, were founded on a bed of horizontal beams placed on wooden driven piles. In fact, beneath the central house of the block, two systems of piles have been discovered; some of the piles were 7-8 $\mathrm{m}$ in length, 
bent and broken, whilst others were straight but shorter $(5.5-6 \mathrm{~m})$; the latter did not reach the gravel. The use of carbon-14 dating has shown that the longer, broken piles were driven in about 1375 and the shorter ones later on in about 1650, when a new house was built. All the piles are inclined at $20-30^{\circ}$ to the vertical, being a proof of the very large distortion that has taken place. The heads of the piles rotted after emergence so that the buildings were no longer in contact with their original piles and progressively applied pressure to the top of the fill. The heads of the piles show that the block of houses has moved in the direction of the surrounding streets towards the quay, whilst the piles are leaning at an angle away from the houses. Progressively the buildings on the left side exerted their thrust on those on the right side. Cracks in the buildings along the old shoreline were especially important.

Distortion of the wooden piles and buildings is explained, where inclined clay layers exist, by the sliding of the overloaded emerged fill. But elsewhere, it is possible that the distortion may be explained by internal erosions in the gravel, where the fines have been washed out by the percolation of rainfall to a progressively lower water table. Proof of this internal erosion is given by the sudden collapse of old houses within the perimeter of the island during the thirteenth century. The horizontal angular strain was $\tan 25^{\circ}=0.47$ in fivc centurics. This figure corresponds to a horizontal displacement of $0.47 \times 600=282 \mathrm{~cm}$ in 500 years, i.e. an average value of $0.56 \mathrm{~cm}$ per year. However, this value now seems to be $0.1-0.4 \mathrm{~cm}$ per year, which compares with the rate of emergence of $0.4 \mathrm{~cm}$ per year. This Stockholm record is a very interesting case of considerable distortion in the long term, due to the three important factors of emergence, internal erosion and sliding on a clay layer.

\section{Damage to old structures due to lowering of the groundwater table}

It has been pointed out that the sudden collapse of many towers has remained unexplained: the central tower at Ely stood for about 200 years and fell in 1322; the central tower at Chichester was built during 1244-1247 and collapsed in 1861. It has been suggested that these accidents could be explained by seasonal or systematic changes in the groundwater level, and the case of Santa María la Real del Sar has been quoted earlier in the Paper.

Often the lowering of the groundwater level is not the only explanation for the collapse but it appears to be a major contributor when combined with excessively loaded foundations and it is interesting to look at the recent behaviour of two well known domes-St Paul's Cathedral, London (Thomas and Fisher, 1974) and the Duomo of Milan. Both have the same height $(108 \mathrm{~m})$ but the former is very much heavier, its weight being carried by eight piers and four bastions as compared with four piers in Milan; finally, the perimeter weight at each of the four

Table 9

\begin{tabular}{|c|c|c|c|c|c|}
\hline 1 & 2 & 3 & 4 & 5 & 6 \\
\hline Depth, m & $\begin{array}{l}\text { Virgin ground } \\
\text { pressure, } \\
\mathrm{kN} / \mathrm{m}^{2}\end{array}$ & $\begin{array}{c}\text { Imposed ground pres- } \\
\text { sure following construc- } \\
\text { tion in the pillar axis*, } \\
\mathrm{kN} / \mathrm{m}^{2}\end{array}$ & $\begin{array}{l}\text { Total pressure } \\
\text { Col. } 2+\text { Col. } 3 \\
\text { kN/m }\end{array}$ & $\begin{array}{l}\text { Surcharge pressure } \\
\text { due to lowering water } \\
\text { table from }-16 \mathrm{~m} \text { to } \\
\quad-40 \mathrm{~m}, \mathrm{kN} / \mathrm{m}^{2}\end{array}$ & 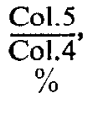 \\
\hline $\begin{array}{l}10 \\
20 \\
30 \\
40 \\
50 \\
60\end{array}$ & $\begin{array}{r}180 \\
360 \\
540 \\
720 \\
900 \\
1080\end{array}$ & $\begin{array}{r}700 \\
350 \\
250 \\
200 \\
100 \\
50\end{array}$ & $\begin{array}{r}880 \\
710 \\
790 \\
920 \\
1000 \\
1130\end{array}$ & $\begin{array}{r}0 \\
28 \\
98 \\
168 \\
168 \\
168\end{array}$ & $\begin{array}{c}0 \\
4 \\
12 \cdot 4 \\
18 \cdot 3 \\
16 \cdot 8 \\
14 \cdot 8\end{array}$ \\
\hline
\end{tabular}

* Taking into account the effect of neighbouring pillars. 


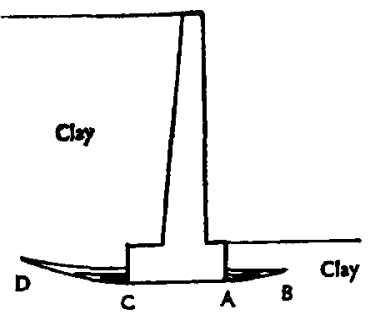

Fig. 33. Mechanism of collapse of old retaining walls

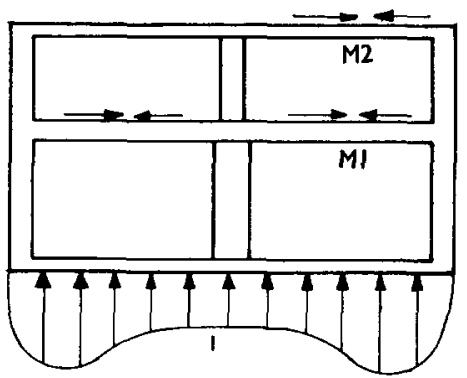

Fig. 34. Reinforced concrete framed building; adaptation to the induced soil stresses

angles is $1900 \mathrm{kN} / \mathrm{m}$ for St Paul's against $1400 \mathrm{kN} / \mathrm{m}$ at Milan, the pressure at Milan being a little higher $\left(750 \mathrm{kN} / \mathrm{m}^{2}\right.$ against $\left.600 \mathrm{kN} / \mathrm{m}^{2}\right)$. In any case, these figures are high (Table 5) and make them sensitive to external events. Both structures have settled recently, moderately for St Paul's (10 mm from 1920 to 1970), more substantially in Milan (15 mm from 1961 to 1969). St Paul's dome is founded in brick earth $(1.2 \mathrm{~m}$ to $2 \mathrm{~m})$ and Thames gravel $(6 \mathrm{~m})$ over London Clay. The presence of brick earth and London Clay as well as a moderate drop of the water table make it a difficult case to analyse (Skempton, 1973) whereas in Milan the main reason for the settlement is certainly a $25 \mathrm{~m}$ drop of groundwater level from $-16 \mathrm{~m}$ to $-40 \mathrm{~m}$. Milan cathedral lies on a deep stratum of sand and gravel, with some silty sand interbeds and some silty layers approximately $0.1 \mathrm{~m}$ thick. The compressible layers below $-40 \mathrm{~m}$ were surcharged, with the lowering of the water table, by $(40-16)(1-n) \mathrm{kN} / \mathrm{m}^{2}$, where $n=$ porosity; for $n=0 \cdot 3$, there was a surcharge of $168 \mathrm{kN} / \mathrm{m}^{2}$, the surcharges of the other layers being smaller. It is interesting to note how the 'reserve strength' theory is applicable in this case, according to which no settlement occurs in a soil as long as the surcharge does not exceed a given percentage of the existing load, this percentage increasing with the time during which the existing load is applied (Bjerrum, 1973). Table 9 shows the value of this percentage for the pillars of Milan cathedral for various depths.

The dome was completed in 1500 . The 'reserve strength' for 470 years of imposed load should not be greater than $18 \%$ and is probably not more than $10-15 \%$, yet the settlements under increases in load of this order of magnitude were appreciable. In this case the observed 'reserve strength' results obtained are lower than those predicted by Bjerrum.

\section{PART 2}

In this section, the stability and behaviour of old retaining walls, old buildings under the effects of nearby open excavations and tunnelling operations, and old tunnels will be examined. 


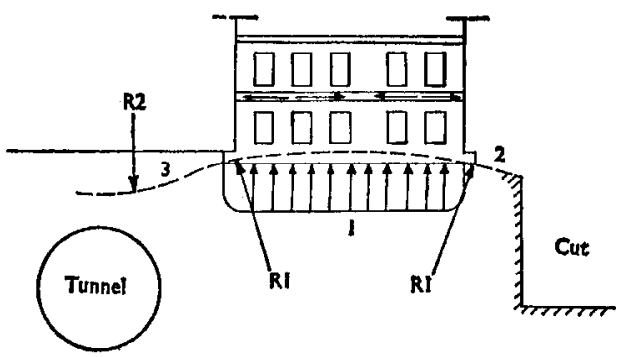

Fig. 35. Old building: adaptation to soil pressures and subsequent convex soil deformations

\section{Retaining walls}

The most frequent long-term accidents involving retaining walls are those where the walls are founded in and support a clay mass. The mechanism of deformation is well understood: a small displacement of the base of the wall is necessary to mobilize passive resisting pressures; with this movement, strain softening occurs with the development of slip bands (Fig. 33). The development of slip bands through all stages of development up to wall failure has been observed in a series of remarkable model tests by Roscoe (1970). Well documented studies have been carried out at Imperial College by Skempton (1964) on the behaviour of retaining walls in stiff fissured clays. The re-examination of delayed failures, in term of effective stress has led to the very important concept of residual properties.

Residual properties in clays can be reached only if the deformations are not constrained and in this respect old retaining walls are very different from braced ones, where lateral deformation of the soil mass is normally limited. However, old retaining walls in sandy silts can also collapse in the same way, especially if their initial safety factor had been low.

\section{Old buildings near tunnels or open excavations}

Soil engineers are asked more and more to predict the behaviour of buildings near to tunnels or open excavations. The majority of such buildings, found in the centre of towns, tend to be old; and the problem is essentially not one of speculation, but rather of practical prediction.

The reaction of the soil on the base foundation of a typical modern reinforced concrete building such as shown in Fig. 34 is often in the form of curve 1, causing a concave deformation, a bending of the base slab and a compression of the structural members M1 and M2. If, however, the relatively rigid old building of Fig. 35 is considered, the curve of the soil reaction is usually flattened out (particularly for buildings on soft soils) such that no horizontal precompression exists in the floors. If, in either of the cases mentioned, the building were to be surrounded by a large open cut or a tunnel dug nearby, the ground surface settlements of the type 2 or 3 in Fig. 35 would result, and the modern building would be in less danger than the old one for the following reasons:

(a) the precompression existing in the floors;

(b) the possibility for them to resist traction forces;

(c) the possibility for the base slab to resist the tangential forces imposed on the foundation by the extensive strain ${ }^{10}$ corresponding to a convex deformation such as 2 or 3 .

${ }_{10}$ For convex soil deformations, extensive strains of $2 \mathrm{~mm} / \mathrm{m}$ (corresponding to a radius of $4 \mathrm{~km}$ ) have been measured (Luetkens, 1957). For a building $10 \mathrm{~m}$ in length, they would correspond to an extension of $2 \mathrm{~cm}$. 


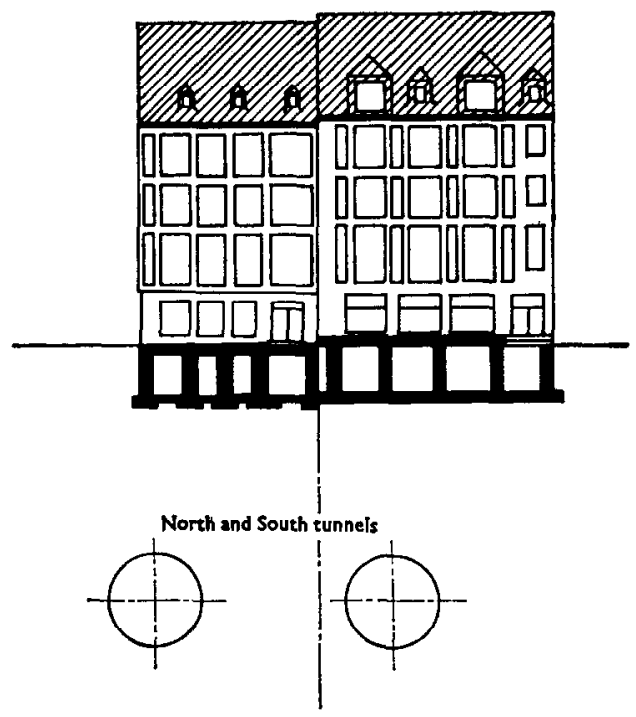

Fig. 36. Sonnerberg Nr 26-28 (Chambosse, 1972)

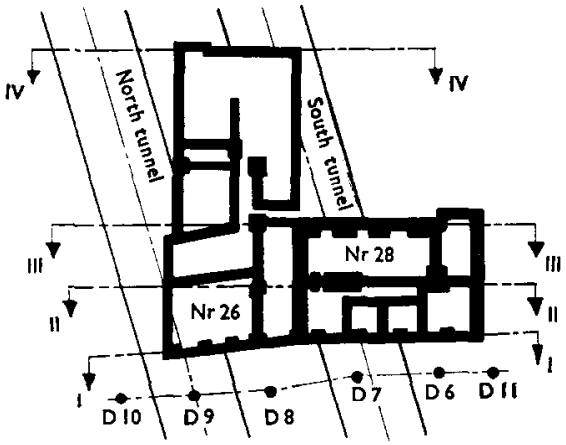

(a)

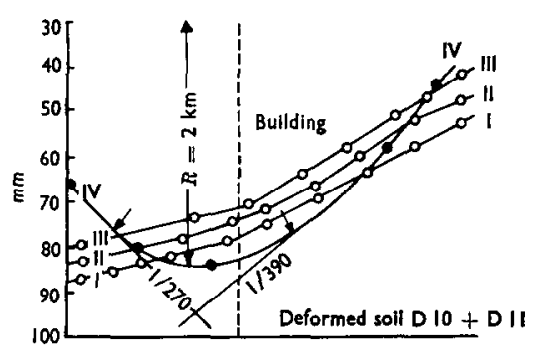

(b)

Fig. 37. Sonnerberg Nr 26-28 (Chambosse, 1972): (a) plan; (b) soil and building deformation

The smaller the radius of curvature of the deformed soil, the greater the danger for the old buildings. Convex deformations are far more dangerous than the concave ones, for the three reasons mentioned. The calculation of the flexibility of an old building is complicated, the only practical approach being to find a correlation between the soil curvature, curvature of adaptation, type of structure and the amount of damage occurring during the adaptation. This problem is different from the adaptation to soil of an old building under its own weight, because there is an external cause.

Buildings near tunnels. Observations such as those made by Chambosse (1972) and Breth and Chambosse (1974c) on the Frankfurt underground system are of particular interest. Figs 36 and 37 (a) show two three-storey modern reinforced concrete buildings in elevation and in 

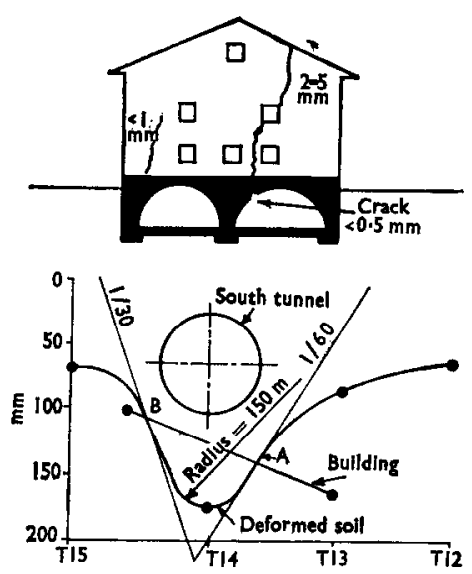

Fig. 38. Dominikanergasse Nr 5: north side (Chambosse, 1972)

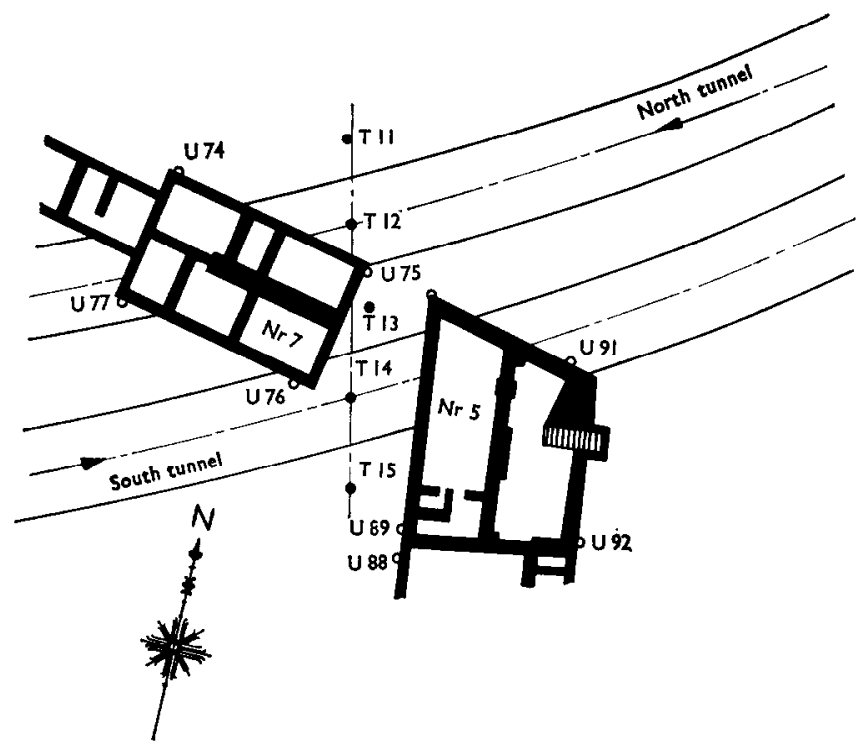

Fig. 39. Dominikanergasse Nr 5 and Nr 7: plan (Chambosse, 1974)

plan. The building has adapted itself without cracking to the line of curvature of the soil deformation, the radius of which can be calculated to be $2 \mathrm{~km}$ (Fig. 37 (b)). For comparison, a second modern three-storey building, Fahrgasse Nr 21-23, also of reinforced concrete, suffered slight fractures (cracking) at a deformation curvature whose radius has been calculated to be only $400 \mathrm{~m}$. Therefore, the critical radius of curvature of soil deformation for threestorey buildings of this type is between 0.4 and $2 \mathrm{~km}$.

In contrast, Chambosse (1972) shows (Fig. 38) a much more serious fracture on the face of the north wall of the building Dominikanergasse $\mathrm{Nr} 5$, built on eighteenth century foundations, underneath which runs one of the tunnels at a slanting angle (Fig. 39). The radius of curvature of soil deformation was only $150 \mathrm{~m}$ and the building was severely damaged. Breth and Chambosse 


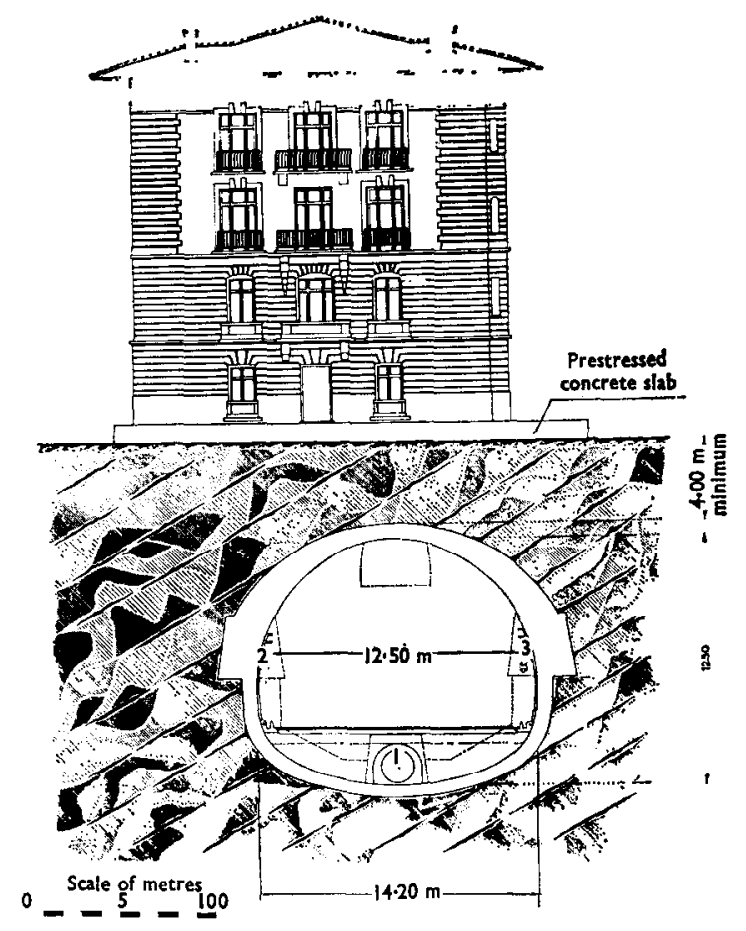

Fig. 40. Cimiez (Nice) tunnel under Villa Castel: north-south cross-section

(1974c) finish their study without differentiating between old and new buildings. They conclude that the important parameter is that of the ratio between height and length and that as long as the numerical value for a given building is greater than one, the walls may be assumed to act like rigid plates. This ratio of height to length is indeed important as has been previously pointed out by Burland and Wroth (1974). However, whereas this may be taken automatically for modern reinforced concrete multistoreyed buildings, it needs to be adjusted accordingly for old buildings. Consider for example the case of the building 'le Castel' situated above a road tunnel passing through the hill of Cimiez in Nice (Fig. 40). The large tunnel passes close beneath le Castel, a building dating from the beginning of the twentieth century. In order not to harm it too much its foundations, made of continuous footings, had been sunk into a prestressed concrete slab. At the beginning of the excavations of three of the four starting galleries (the lower gallery (1) and lateral galleries ( 2 and 3 ) in Fig. 40), the radius of curvature of the concrete slab on the north side (façade) became $8.75 \mathrm{~km}$ with a convex deformation. In spite of this large value, a very large crack developed at the top of the outer staircase (Fig. 41) which was an element of weakness reducing the beneficial effect of the ratio $H / B$.

When rigidity is uniform, the strain is spread between a large number of very fine cracks which are not considered significant. In accordance with the law of least resistance to deformation, when rigidity is heterogeneous the smallest weakness in the masonry structure will be the most vulnerable. For this reason, the most important faults often appear at the junction of two walls of different rigidities, and a chain of walls (Fig. 37 (b)) will deform as a series of straight lines rather than a continuous curve, the adaption curve of each wall on the soil frequently being a straight line. 


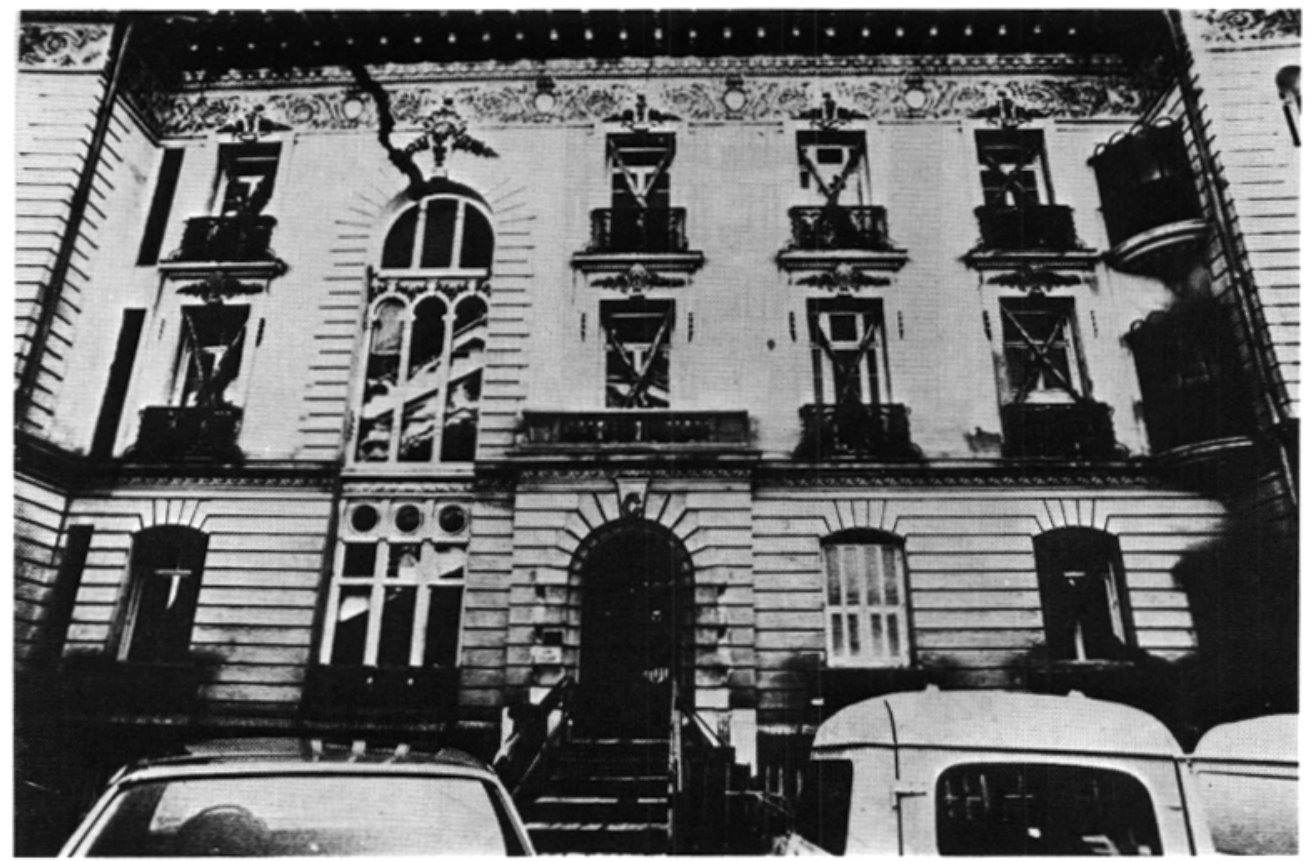

Fig. 41. North façade of Villa Castel

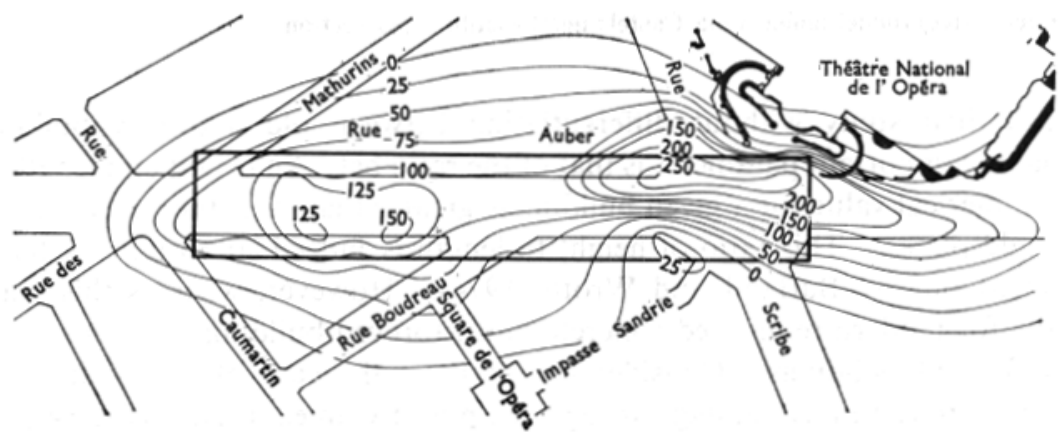

Fig. 42. Ground heave contours $\left(10^{-4} \mathrm{~m}\right)$ after grouting above Auber underground station, Paris

At Frankfurt, the undulations of the soil are eliminated, the high points being levelled by the rigidity of each building: the cracks in the building are generally seen either at junctions between two buildings or on oblique lines along the edge of the area of levelled soil, where shearing stresses are greatest.

In Paris, most of the buildings situated directly or almost above the express underground are masonry buildings with steel joisted floors, dating from the beginning of the twentieth century. Most of the cohesionless soils are grouted and generally the RATP tries to obtain 5-15 mm (exceptionally $20 \mathrm{~mm}$ ) heave of the soil before excavation of the tunnel in order to reach a net settlement of not greater than $15 \mathrm{~mm}$ so as to avoid small radii of curvature of soil surface deformations. For example, before construction of the large Auber station in Paris $25 \mathrm{~m}$ wide and $300 \mathrm{~m}$ long, grouting from starting galleries resulted in a soil deformation shown in Fig. 42 (Kerisel and Lupiac, 1973). The corresponding radius of curvature in the transversal direction (heave of $0-15 \mathrm{~mm}$ over $2 \times 250 \mathrm{~m}$ in width) is $(250)^{2} /\left(2 \times 1 \cdot 5 \times 10^{-2}\right)=85 \mathrm{~km}$. With 


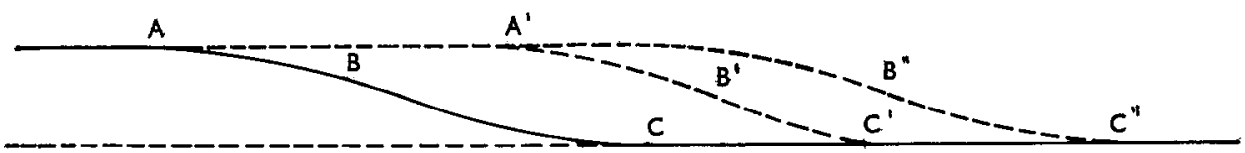

Fig. 43. Longitudinal waves after grouting

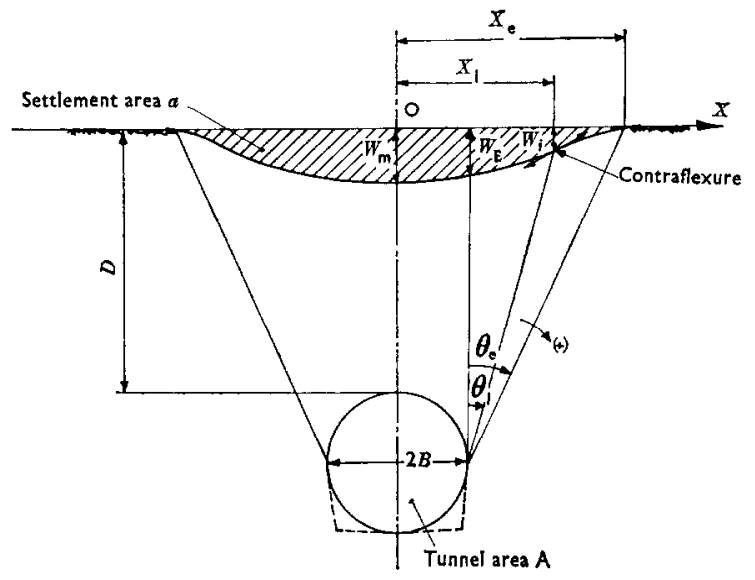

Fig. 44. Definition of settlements

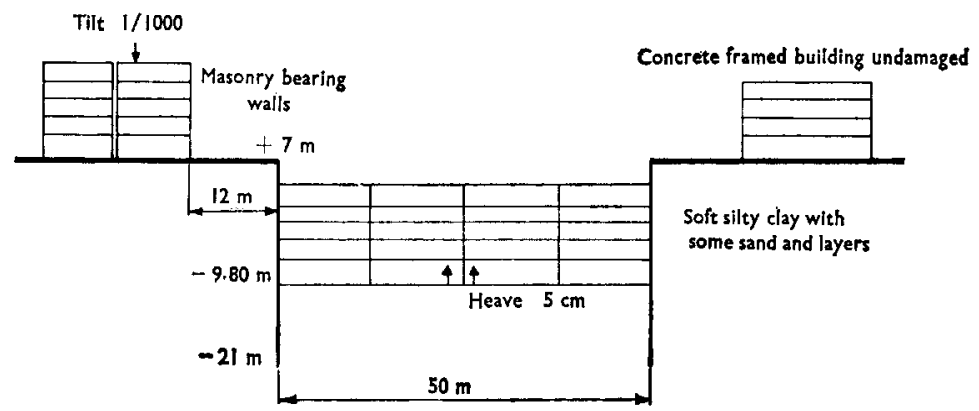

Fig. 45. Deep cut in soft soil in Nice

the advancement of the injections, a longitudinal wave of surface deformations was observed. With progression, the radius of curvature was maintained at large values (Fig. 43). In Paris, the settlements are expressed as a function of the parameters shown in Fig. 44 . It has been estimated that the settlement does not necessarily have the shape of a probability curve (Peck, 1969) but, rather, is independent of the size of the tunnel and can be described by the angles $\theta_{\mathrm{e}}$ and $\theta_{\mathrm{i}}$ (classical in studies of mining subsidence) and also by the settlements $W_{\mathrm{m}}$ and $W_{\mathrm{i}}$ at the contraflexure point. The radius of curvature of the concave deformation is given by

$$
\frac{x_{1}^{2}}{2\left(W_{\mathrm{m}}-W_{1}\right)}=\frac{\left[B+(D+B) \tan \theta_{1}\right]^{2}}{2\left(W_{\mathrm{m}}-W_{1}\right)}
$$

It has been found that $\theta_{1}$ lies between $-20^{\circ}$ and $+20^{\circ}$. It is normal practice to quote the efficiency (vis-à-vis damage to buildings) by the ratio $a / A$ of the settlement area (Fig. 44 ) to the excavated surface. The value of $a / A$ under Paris (intra muros) is less than $0.5 \%$. The radii of curvature of the soil for convex and concave deformations are generally respectively 5 and $10 \mathrm{~km}$ or more. Damage to buildings, even old ones, has been insignificant. 


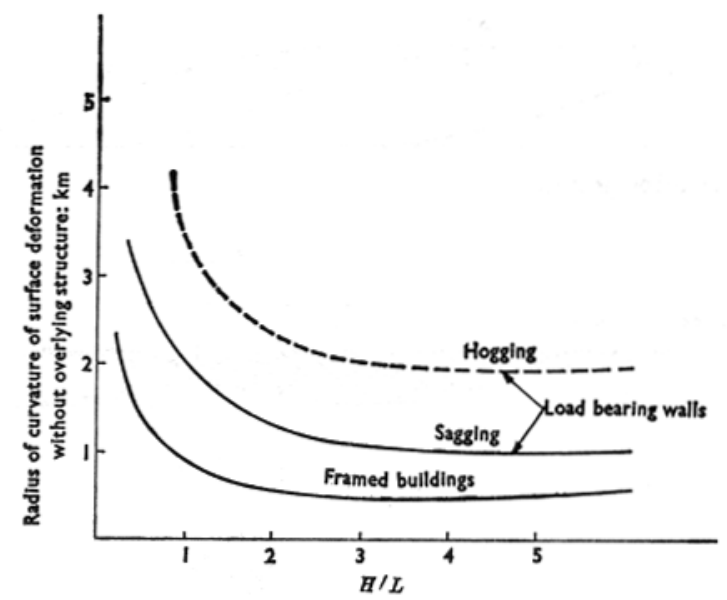

Fig. 46. Critical radius of curvature

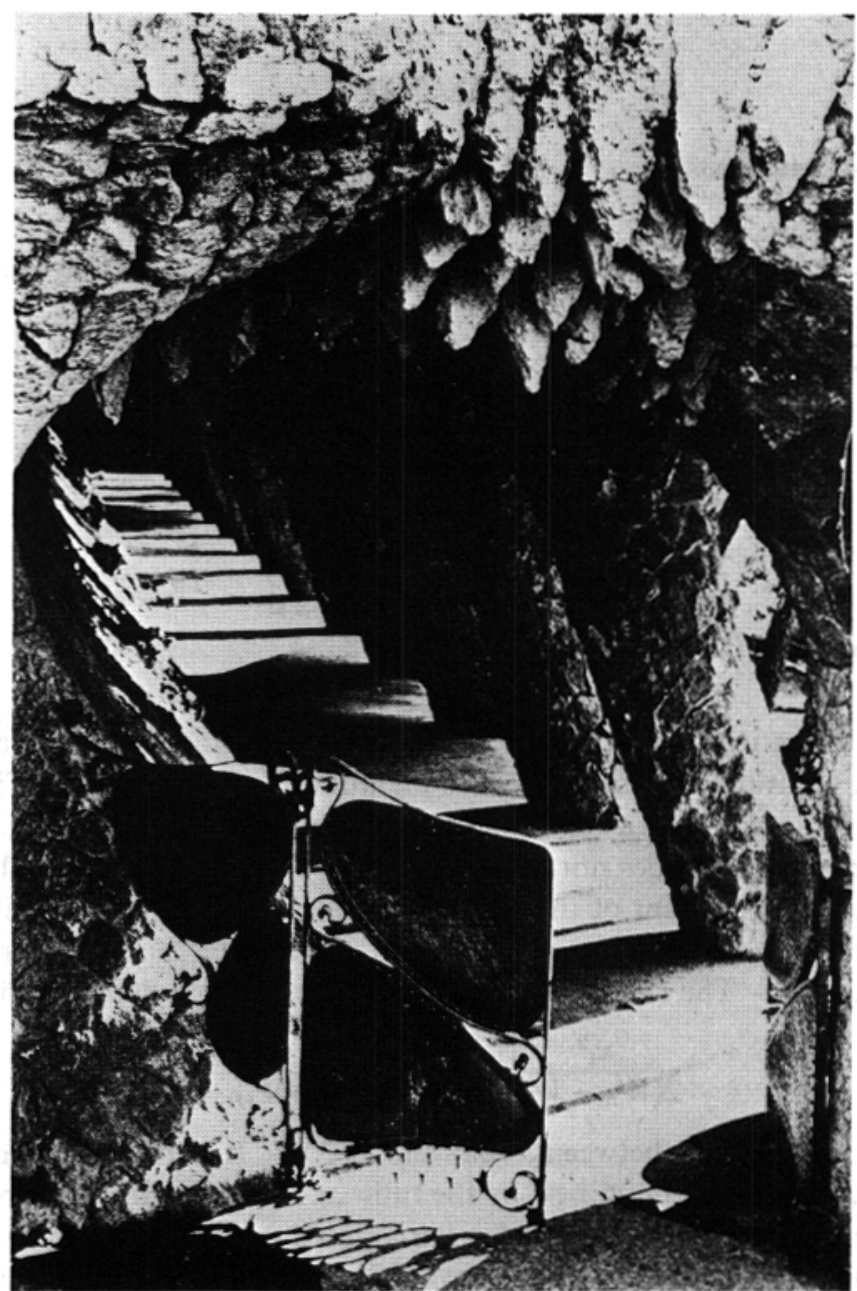

Fig. 47. Gaudi's semi-interred walkway 


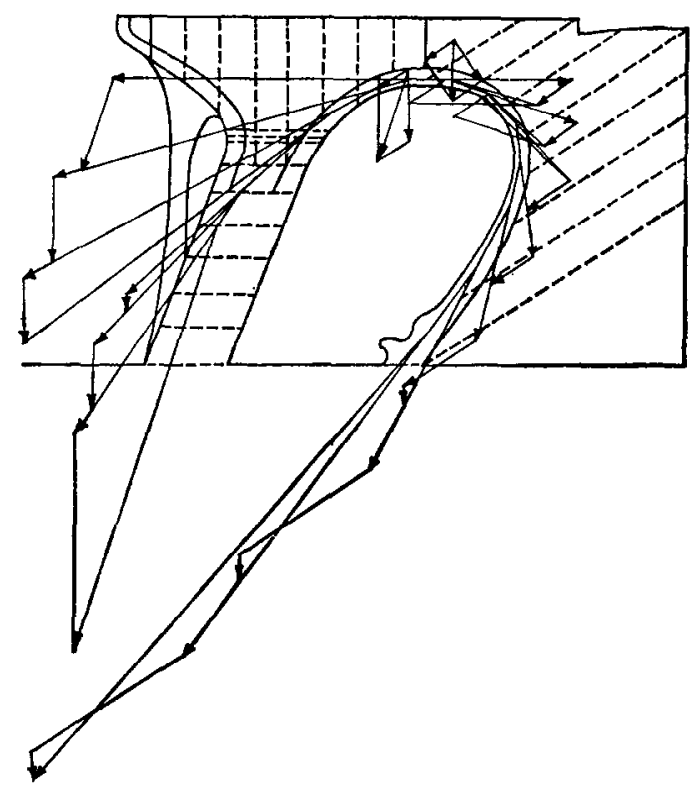

Fig. 48. Representation of forces acting on Gaudi's walkway

Old buildings near to an open excavation. Without doubt, old buildings are very susceptible to convex deformations caused by nearby cuts. The case is quoted of an open excavation $50 \times 50 \mathrm{~m}$ in length and breadth, and $16.80 \mathrm{~m}$ in depth, sheet piled in soft soils to a depth of $28 \mathrm{~m}$ in Nice (Fig. 45). In spite of the high ratio $28 /(16 \cdot 80)$, a $5 \mathrm{~cm}$ heave of the bottom was observed; five levels of bracing were used but nevertheless a convex soil deformation took place around the excavation. Around the periphery of the excavation, the modern reinforced concrete buildings suffered no damage whereas the older buildings, dating from the beginning of the twentieth century, experienced a degree of damage with tilting of about 1/1000.

If one is forced to make conclusions concerning the radius of curvature of ground deformation (caused by external causes such as excavations or tunnels) below which there is a danger of damage, a graph of the type indicated in Fig. 46 is proposed, based on some characteristic examples. The length $L$ is that of a building independent of its neighbour. Two separate curves are proposed for old buildings, one related to hogging deformation, the other to sagging; they suppose a rather uniform rigidity. Both curves have to be translated upwards if floors are wooden and downwards if the masonry walls are mortared with fat lime or the floors steel joisted.

\section{Deformation of old tunnels}

In order to mention the transition between closed and open buried structures, a work of the Spanish architect, Gaudi (1853-1926) may be cited. Avant-garde in his period, in 1900 he created the Park Güel (Montaña Pelada, Spain) urban complex of 15 ha and designed (Fig. 47) for earth pressures acting on the surface of a semi-interred walkway, which he surrounded with inclined columns (Fig. 48).

The deformation of old tunnels leads to a subject very different from those already mentioned. One is concerned with composite bending, i.e. the normal force plays an important part. The problem of appreciating the safety of these old structures poses a practical question, very important in France today, after the unexpected collapse of a 140-year old tunnel which had 


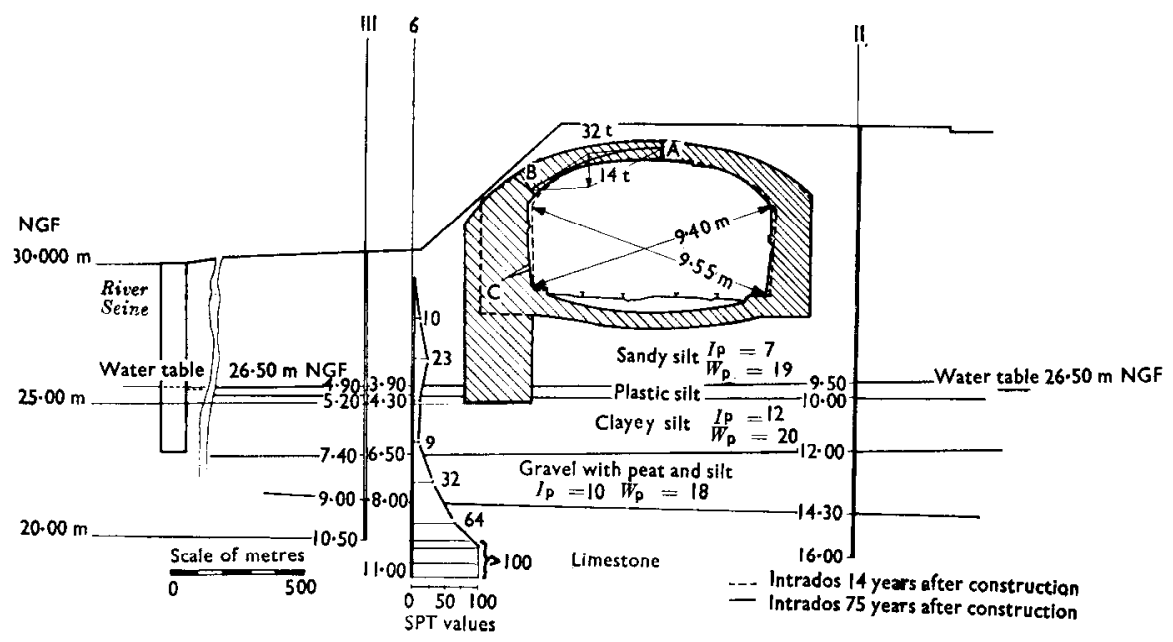

Fig. 49. Deformation under asymmetrical lateral forces

been inspected at regular intervals. The length of most tunnels in France more than 100 years old is of the order of $1500 \mathrm{~km}$. In this section, three characteristic types of lining deformation will be described.

Distortion due to asymmetrical horizontal forces. In the case of tunnels fringing a valley, distortion is often due to asymmetrical horizontal forces. The horizontal forces of the high side are clearly greater than those of the river side, resulting in a distortion of the tunnel, often aggravated by a general pivoting due to loose foundations on the low side. The SNCF tunnel at Orsay-Austerlitz in Paris, along the Seine beneath the Place Valhubert, provides a good example (Fig. 49). It was constructed in 1900; dotted lines in Fig. 49 represent a section fourteen years after the tunnel's construction, and the plain lines represent the section in 1974 before repair works were begun with visible articulated sections $\mathrm{A}, \mathrm{B}$ and $\mathrm{C}$ as indicated. The tunnel had $2.00 \mathrm{~m}$ diameter anchoring pillars at $8 \mathrm{~m}$ intervals to prevent the whole assembly from rotating. However, these pillars, as indicated in the geotechnical section, did not go right through the layer of compressible clayey silt to reach the lower limestone bed, and the resistance they could provide to a rotation of the structure was therefore limited. By comparing the lengths of the diagonals, 9.40 and $9.55 \mathrm{~m}$, it can be seen that today there is a distortion of the order of $1 / 120$. It is well known that the distortion results from the compressibility of the soil beneath the pillars, and from the significant displacement necessary to move the deformable earth mounds lying against the outside of the Seine side supporting walls. Calculated by a trial and error method, the line of thrust is shown in Fig. 49. The maximum stress at $A$ is less than $1 \mathrm{MN} / \mathrm{m}^{2}$. The safety depends above all on the good quality of the stone in zone 1 near B, and on its resistance to oblique shearing forces. This tunnel is interesting because of the information it yields as to the position of the hinges. For conservation, the upper part has to be replaced by a portico.

Nicoletti and Keith (1969) give another good example: the Southern Pacific Railroad tunnel (1906) in San Francisco; after the later freeway cutting (1966) and the construction of its retaining walls, lateral forces in the west side of the tunnel predominated and movements were detected in the tunnel. The entire western side was moving inwards at a rate of $0.6 \mathrm{~mm}$ per day. All movements were eliminated by the creation of the portal shown in Fig. 50 . 


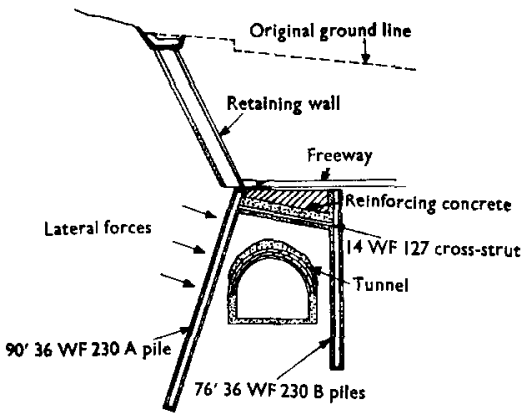

Courtesy $A S C E$

Fig. 50. Lateral differential forces: San Francisco

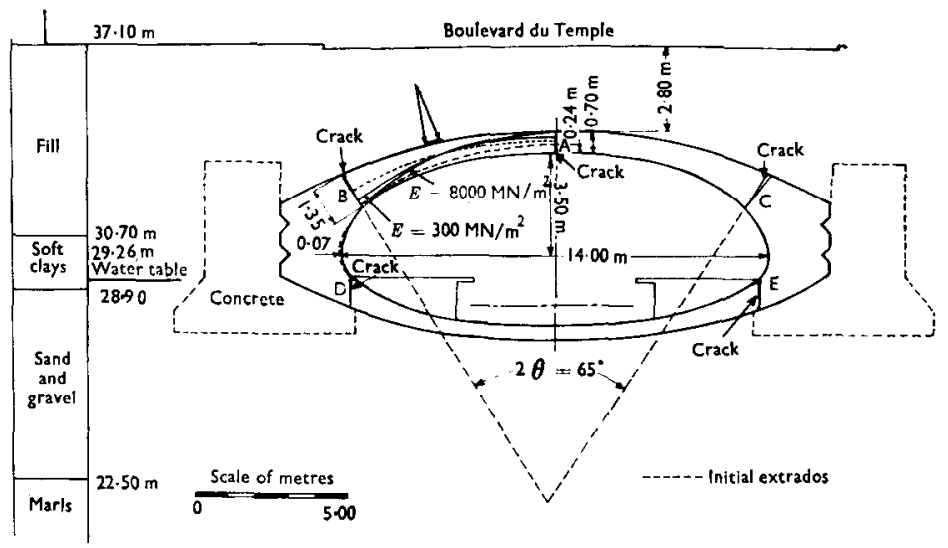

Fig. 51. Filles du Calvaire underground station

Deformation due to lack of horizontal passive pressure: flattening. This type of deformation occurs in tunnels built during the nineteenth century when lateral external wooden shuttering was left in the lateral space between the supporting walls and the ground. This was also the case for underground works laterally surrounded by soft ground such as those built in an old river bed. An example of this type is the underground railway station Filles du Calvaire, in Paris. Built about 1930, by 1960 it was showing serious signs of dilapidation associated with its being situated in a one-time branch of the Seine. The station, with a small rise, was founded on good quality sands and gravels, but laterally easily deformable owing to mud and clay loams. What is interesting in the case of this station is that there exists a five-hinge mechanism (Fig. 51), three in the vault (A, B and C) and two (D and E) in the curved raft (four-bar chain). It is very unusual to be able to see simultaneously these five joints. The dotted lines in the figure indicate the lateral reinforcement walls which were built after 1960 in order to limit vertical vault settlement by limiting possible horizontal movements. Of the three hundred underground stations in Paris there are three others in analogous situations vis-à-vis insufficient lateral earth support. They were all built about 1930. The vaults are also of masonry in opus incertum with artificial cement mortar throughout the width. These three stations exhibit only three hinges, one at the crown and two others at the haunches of the vault. Superimposing the original profiles on to recent photo-profiles it can be seen in these four stations that there is a crown settlement with no discernible displacement of the haunches B and C (Fig. 51). 
Table 10 gives the mid-sectional total horizontal strain, at the level of the haunches, the relative horizontal strain, the crown settlement and the vertical strain of the rise. The angle $2 \theta$ is the angle subtended between the perpendiculars to the geometrical axes at the fissured haunches. The line bisecting this angle is not always vertical (deformation slightly asymmetrical with respect to the vertical). It is found that the value of $2 \theta$ is relatively constant with a mean value of $30-35^{\circ}$ for $\theta$.

Suppose that the stonework can be characterized across its section in stone and mortar by a single Hooke's modulus, which is perhaps an oversimplification but which is nevertheless, at the present state of the art, the only possible approach to the problem. It could be assumed that in starting from the crown $A$ where the rotation $\omega$ is insignificant and the vertical deformation $V_{\mathrm{A}}$ that of Table 10, that at the haunch $\mathrm{B}$ the vertical deformation $V_{\mathrm{B}}$ is zero and that the rotation $\omega_{B}$ is that which appears on the photo-profiles at full scale.

$$
\begin{gathered}
\omega_{\mathrm{B}}=\int_{A}^{B} \frac{M}{E I} \mathrm{~d} s \\
O=V_{\mathrm{A}}-\int_{A}^{B} \frac{M}{E I}\left(X_{\mathrm{B}}-X\right) \mathrm{d} s-\int_{A}^{B} \frac{N}{E S} \sin \alpha \mathrm{d} s
\end{gathered}
$$

$\alpha$ is the angle from the geometrical axis to the horizontal.

Let this calculation bc applied to Filles du Calvaire station (Fig. 51) where $\omega_{B}=0.02$, $V_{\mathrm{A}}=0.24 \mathrm{~m}$ and $X_{\mathrm{B}}=6.75 \mathrm{~m}$. The observed value of $\omega_{\mathrm{B}}=0.02$ corresponds well to the observed $2 \cdot 5-3 \mathrm{~cm}$ crack widths measured in a trial pit at the back of the arch). It has been assumed that $N$ is constant and equal to the mean load $\gamma H$ on the arc AB multiplied by the mean radius of curvature $R$ of the arc: $\gamma H \times R=7 \mathrm{t} / \mathrm{m}^{2} \times 12 \mathrm{~m}=84 \mathrm{t} / \mathrm{m} . \quad I=h^{3} / 12$ has also been calculated, assuming $h$ to be equal to the thickness of the arch whenever the resultant lies within the central third and equal to three times the distance between the edge of the section and the thrust line, when the latter was found to lie outside the central third. The arc AB has been divided into eight equal sections and by successive approximations the points through which the resultant passes have been determined as shown in Fig. 51. On introducing an eccentricity at the crown, a corresponding eccentricity also appears at the haunches as well at point A. Table 11 summarizes the calculation for Filles du Calvaire station. The resultant

Table 10. Deformation of four underground stations

\begin{tabular}{l|c|c|c|c|c}
\hline & $\begin{array}{c}\text { Total widening, } \\
\text { cm }\end{array}$ & $\begin{array}{c}\text { Horizontal } \\
\text { strain }\end{array}$ & $\begin{array}{c}\text { Crown settlement, } \\
\text { cm }\end{array}$ & $\begin{array}{c}\text { Vertical } \\
\text { strain }\end{array}$ & $\theta$, degrees \\
\hline Filles du Calvaire & $0 \cdot 14$ & $1 / 100$ & 0.24 & $1 / 16$ & $32 \cdot 5$ \\
Montreuil & 0.08 & $1 / 280$ & 0.05 & $1 / 130$ & 32 \\
Félix Faure & 0.08 & $1 / 175$ & $0 \cdot 10$ & 1.50 & 30 \\
Lourmel & 0.27 & $1 / 47$ & 0.10 & $1 / 47$ & 30 \\
\hline
\end{tabular}

Table 11. Position of thrust line

\begin{tabular}{c|c|c|c|c}
\hline \multirow{2}{*}{ Modulus $E, \mathrm{MN} / \mathrm{m}^{2}$} & \multicolumn{2}{|c|}{ Eccentricity } & \multicolumn{2}{c}{ Maximum stress, MN $/ \mathrm{m}^{2}$} \\
\cline { 2 - 4 } & At the crown & At the haunches & Crown (extrados) & Haunches (intrados) \\
\hline 300 & $0 \cdot 20$ & 0.27 & $2 \cdot 7$ & 1.8 \\
8000 & 0.40 & 0.41 & 8.0 & $5 \cdot 1$ \\
\hline
\end{tabular}




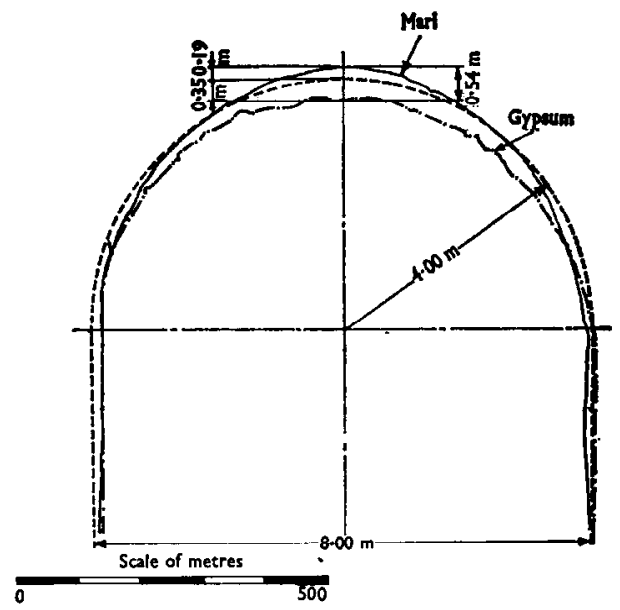

Fig. 52. Blaizy-Bas railway tunnel lining deformations in expansive marl and in gypsum

evolves between the two solid lines shown in Fig. 51. It can be seen that a large change in the assumed value of modulus $E$ incurs only a small displacement in the position of the thrust line. The principal difficulty in this sort of problem is essentially one of predicting the actual modulus of deformation of the masonry. It is therefore surprising that only very few efforts have been made in this field during the past century. At the very most, only two extreme values for the masonry of the nineteenth century could be found: $3000 \mathrm{MN} / \mathrm{m}^{2}$ for bricks and mortar and $25000 \mathrm{MN} / \mathrm{m}^{2}$ for dressed stone (test arch at Souppes, Appendix 1). The hypothesis that $E=8000 \mathrm{MN} / \mathrm{m}^{2}$ is extreme: the corresponding working values of 8 and $5 \cdot 1 \mathrm{MN} / \mathrm{m}^{2}$ would risk causing rupture not only at the crown, but also at the haunches by unrestricted shearing. However, at the crown, the fissure is closed and it is probable that the resultant only shifts slightly from the central half (eccentricity $=0 \cdot 25$ ). The real modulus therefore must have a value of $2000-3000 \mathrm{MN} / \mathrm{m}^{2}$.

Figure 51 shows the soil pressure resultant applied to the exterior of the arch $\mathrm{AB}$ for the thrust line calculated with $E=8000 \mathrm{MN} / \mathrm{m}^{2}$. It should be noted that the value of the tangential component of the soil resultant is approximately one quarter of that of the vertical component. For $E=300 \mathrm{MN} / \mathrm{m}^{2}$, this tangential component is less important but is still substantial, forming an important component in the equilibrium of the system. It is unfortunate that it is not always accorded its due importance.

It may be said that it is almost normal for old arches to develop a mechanism of three articulations. The essential factor is that behind the haunch, in the place where the mechanism tends to re-enter the soil, there are no voids, and moreover, lateral passive pressure is mobilized with moderate displacements. Our predecessors well understood this condition: they loaded the haunches of cathedral flying buttresses to prevent them from lifting (as occurred notably at Amiens). This loading of the haunches is today systematically assured for such arches as those of the Paris underground railway, by grouting the soil behind the arch, particularly at the haunches, after regenerating the stonework.

Deformation due to excessive horizontal pressures: rise of crown. One very interesting case of lateral squeezing by a swelling marl with a raising of the keystone is that of the railway tunnel at Blaizy-Bas which is 140 years old and $4200 \mathrm{~m}$ long. In a section about $1000 \mathrm{~m}$ long, it is subject to lateral action by swelling marls fed by water from layers of interbedded sandstone; 


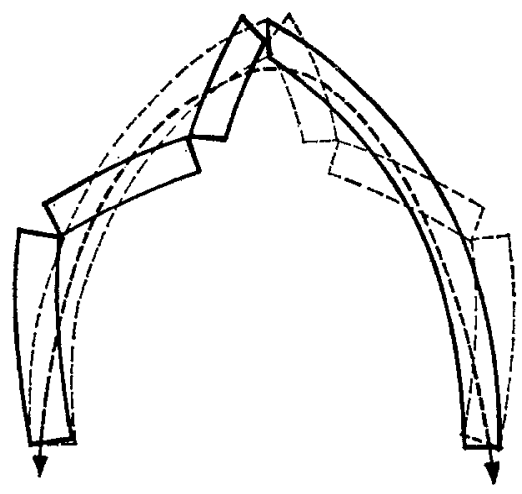

Fig. 53. Failure mechanism of Gothic pointed arch

the deformations are shown in Fig. 52. In other sections, surrounded by excellent Bourgogne limestone, one finds the original profile, and finally, in a third section, the tunnel is situated in gypsum subject to irregular solution under the level of the rails. These deformations are shown superimposed in Fig. 52 together with the original profile and the section within swelling marls. Between the keystones, in the sections most deformed in the marls and the gypsum, there is a height difference of $54 \mathrm{~cm}$. The deformation of the section in the marls with elevation of the keystone matches well the deformation of gothic arches (Fig. 53) when they fissure (Abraham, 1934). The swelling pressure, which is $0.3 \mathrm{MN} / \mathrm{m}^{2}$ creates horizontal forces which divide into normal and tangential components towards the keystone. Both of them tend to lift the keystone out of its seating.

A stable equilibrium is therefore assured as long as the vertical earth load is equal to or greater than the vertical component of the pressures in the keystone (which is the case at Blaizy-Bas owing to the bed of sandstone above the keystone) and provided that the internal stresses in the lining are not excessive-a point which will be examined. In the region of the haunches on the right of Fig. 54 the radius of curvature changed from $4.00 \mathrm{~m}$ to $4.17 \mathrm{~m}$, whilst in the keystone it fell from $4.00 \mathrm{~m}$ to $3.40 \mathrm{~m}$ (relative deformation of $1 / 7$ ). The change in radius of curvature in an elastic arch induces an outer fibre stress $\sigma$, given by

$$
\sigma=E y\left(\frac{1}{R_{1}}-\frac{1}{R_{2}}\right)
$$

where $y$ is the arch rise, $R_{1}$ is the initial radius of curvature and $R_{2}$ is the deformed radius of curvature.

Substituting in eqn (4) the changes in curvature observed at Blaizy-Bas, $\sigma=E y(0.011)$ at the haunches and $\sigma=E y(0.044)$ in the keystone. The difficulty in appreciating the value of $E$ is even more difficult in this case than for Filles du Calvaire station as, like many tunnels of the nineteenth century, the Blaizy-Bas tunnel was constructed of mixed stonework, layered behind, with an opus incertum filling (Fig. 55). The dressed stones of Bourgogne limestone at the intrados are of excellent quality but with thick joints. A great part of the stresses passes through the layered stones ${ }^{11}$ after adaptation of the mortar to the stones joints. This mortar was recently observed in many places to be extruded towards the exterior. A joint of $1 \mathrm{~cm}$ every $40 \mathrm{~cm}$, whose thickness reduces by $20 \%$ on one side, allows a variation of curvature of $(0 \cdot 2 / 40)(1 / 0 \cdot 20)=0.025$ per metre, compared with the variations of curvature 0.011 and 0.044

11 In such tunnels, pressures of $10 \mathrm{MN} / \mathrm{m}^{2}$ in dressed stones have been measured by flat jacks. Even with possible overestimation, these results indicate high pressure values. 


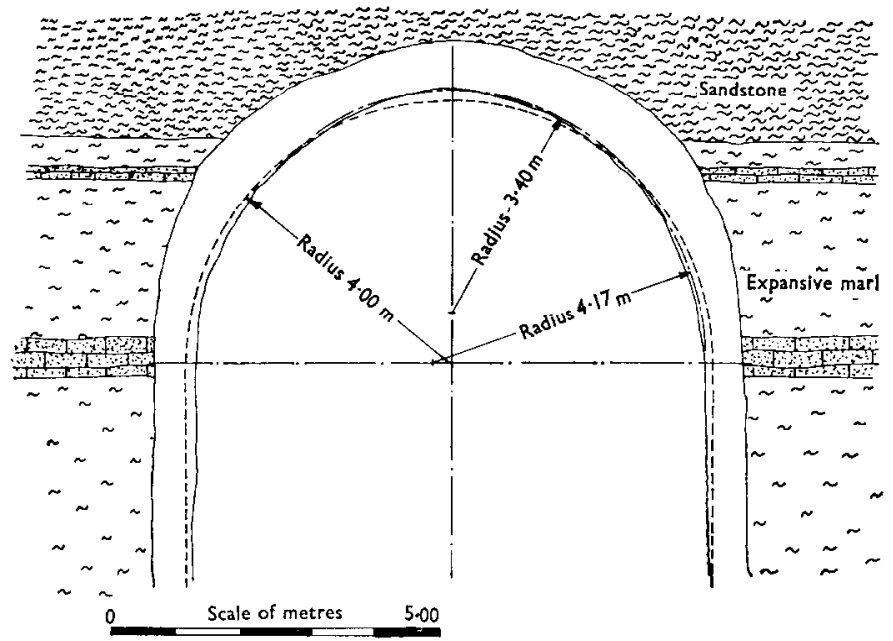

Fig. 54. Blaizy-Bas railway tunnel squeezed by swelling of expansive marls

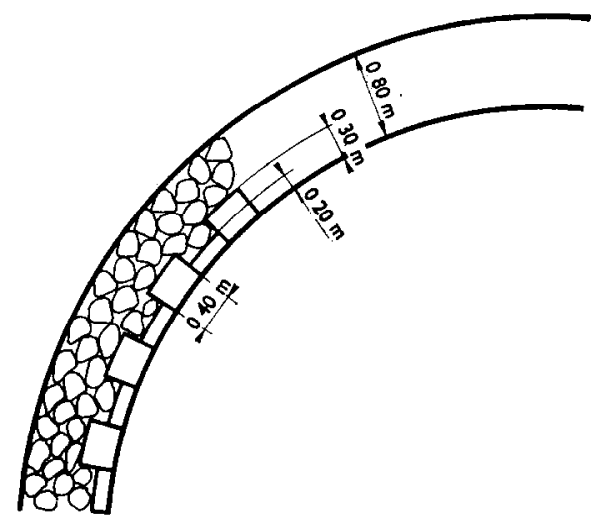

Fig. 55. Typical fabric of old tunnel

deduced in the foregoing text. It is very difficult to fix a definitive modulus of compression for the stonework as a whole since its origin, the value of the modulus $E$, is very much subject to the quality of the mortar and above all, it is a function of the friction of the mortar on the sides of the stones at the time of extrusion, in the same way as for thin interbedded layers of clay in fissured rocks. Attempts are being made to discover the existing stresses as much through theoretical calculations on the circular arch subject to this sort of load, as through experimental determinations from strain gauges attached to few stones in place before removal. In fact no results are yet available as the stones in question are still in the process of being extracted.

Returning to the approximate expression $\sigma=E y(0 \cdot 044)$, and taking $E=2000 \mathrm{MN} / \mathrm{m}^{2}$ and $y=0.10 \mathrm{~m}$ (half of the thickness of the continuous layered stone) one obtains $\sigma=8.8 \mathrm{MN} / \mathrm{m}^{2}$ which is a high value in itself but which can be adequately supported by a dressed stone lining of this type. In fact, it is not the ultimate resistance of the stonework which is in question, but much more the long-term behaviour of a highly stressed stone lining, under the effect of temperature variations and weathering, which could have led to lining decay. 


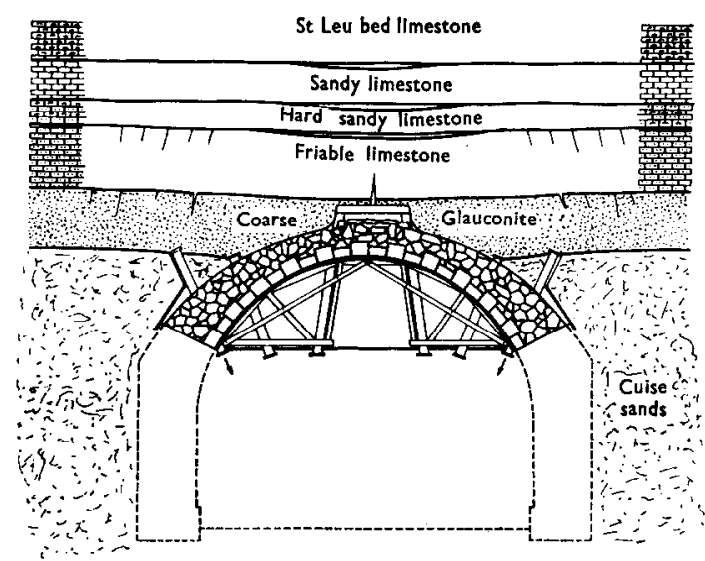

Fig. 56. Vierzy tunnel during construction

Ultimate failure of tunnels. The collapse of the Vierzy double railway track tunnel near Soissons in France in June 1972 resulted in heavy casualties (108 people lost their lives when two trains entering the tunnel from each end at a three minute interval collided with the debris resulting from a sudden collapse of the arch roof along a section $25 \mathrm{~m}$ long). The tunnel itself was $1400 \mathrm{~m}$ long. As the report of the commission of enquiry set up by the minister of transport has been published, it is now possible to describe the causes of this collapse, which was due to the coincidence of numerous factors which thwarted the regular periodic checks.

Cut through the Cuise sands, dominated by a bed of coarse glauconite (Fig. 56) and by several beds of limestone of weak and medium strength, the tunnel involved from the start some basic faults in construction. The head gallery was badly shored at the top and voids were left at the haunches at the junction between the glauconite and the sand. It is probable that these voids provoked the development of fissuring of the overlying limestone (Fig. 56). The construction of foundations piers in sand by an underpinning process aggravated the settlement of the upper layers, probably causing the fracture planes indicated in Fig. 57, in which oxidation occurred over a long period. The explosions from a nearby mine causing local destruction of the tunnel in 1914 doubtless enlarged these fissures. Under these conditions and over a long period, the weight of the soil in the form of a trapezium above the crown, pressed on the arch over a discontinuous surface. The initial masonry was a stone casing (crushing strength $=5.5 \mathrm{MN} / \mathrm{m}^{2}$ ) with mortar and rubble fill (Fig. 56). Between 1935 and 1941 the stone facing was cleaned and trimmed because of weathering, the middle of the vault being refaced with a brick lining. It appears from flat jack measurement made in the brick lining outside the collapsed zone that it supported pressures of $1-2 \mathrm{MN} / \mathrm{m}^{2}$. Like Beauvais Cathedra ${ }^{12}$ where the stone was weak, there was a flow of stone and a transfer of pressure towards the stiffest members of the fabric. The brick lining was being replaced at the time of the accident but the contractor was not following his instructions to replace the lining over only short lengths at a time. Owing to bad workmanship at the time of construction, a local fault (constriction of the vault at the key) existed in the arch at the junction of work by two builders, and the collapse occurred when the replacement of the brick lining reached this fault, delimiting the collapse zone. Finally, when the tunnel collapsed, the contour of the failed soil mass was ABCDEF in Fig. 57. The line of rupture of the arch is that shown in Fig. 58 with a probable

12400 years after building, the soft limestone transept of Beauvais Cathedral still moved, the arches separating by $1 \mathrm{~mm}$ per year. 

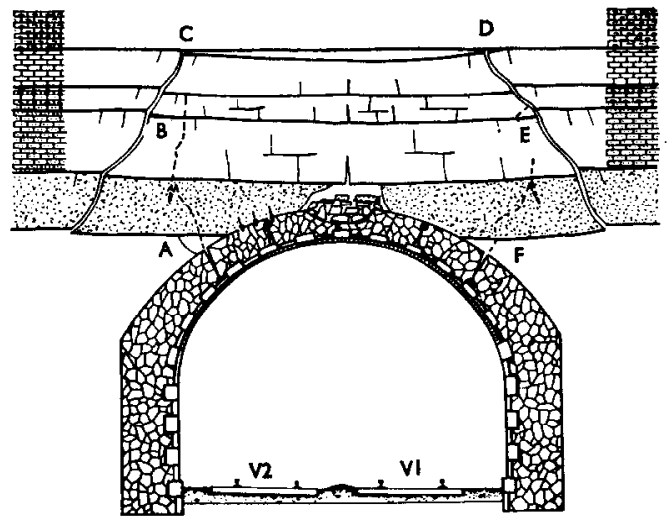

Fig. 57. Vierzy failure just before the accident (assumed)

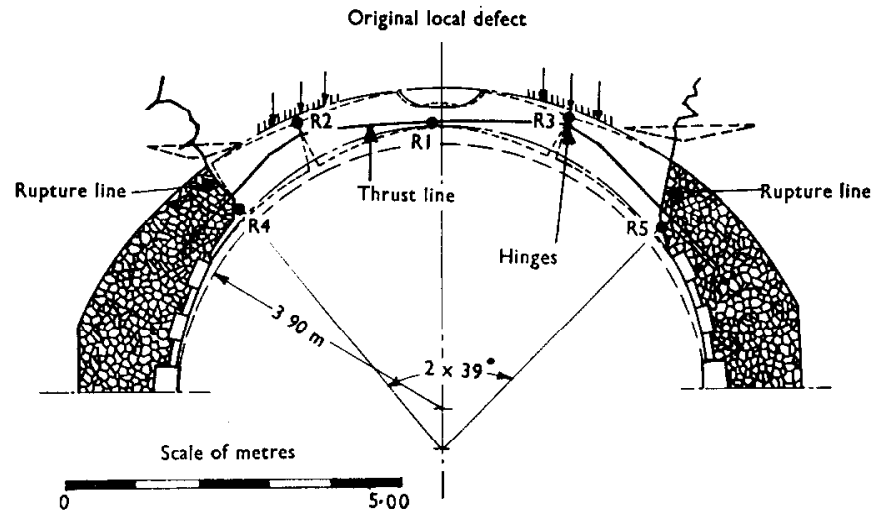

Fig. 58. Vierzy tunnel: detail of rupture lines (possible mechanism)

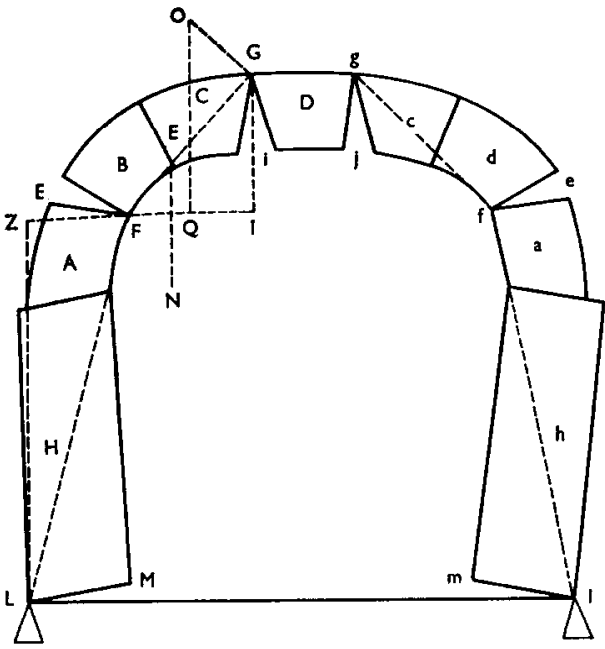

Fig. 59. Danyzy tests (1732) 


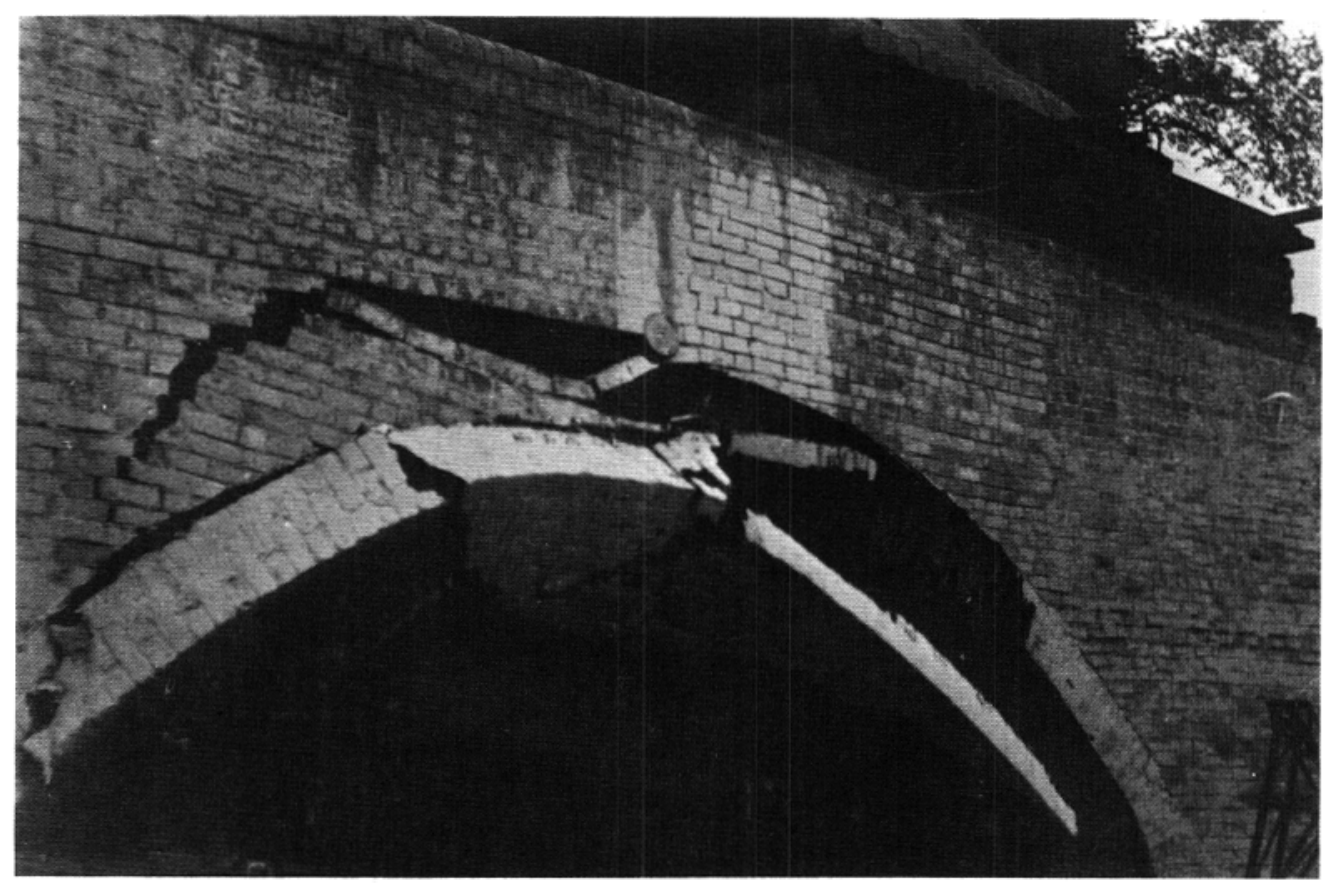

Courtesy BRE

Fig. 60. Yardley Wood road bridge at instant of collapse

failure mechanism which corresponds well to that determined from calculations assuming five plastic hinges. If the weight of the trapezium is assumed to be concentrated only at the two points R2 and R3 then, assuming that there are no local imperfections, the plastic calculations demonstrated that failure would occur when the compressive strength of the stone was equal to one sixth of the crushing strength. This, according to laboratory test data, was not so and it must be concluded that local imperfections were present in the vault.

The mechanism is reminiscent of that presented in 1732 by Danyzy, after tests on plaster voussoirs at the Royal Society of Montpellier and shown in Fig. 59 (after the redrawing by Heyman, 1972). The rupture was initiated probably at the hinges of the haunches $\left(2 \theta=78^{\circ}\right)$ which led to a slip at these points. The slip is similar to that shown (Fig. 60) when the Building Research Station tested to failure the Yardley Wood road bridge.

The Vierzy tunnel was subjected to regular and careful surveillance. However, boreholes driven through the weak limestone could detect the exact shape of the voids only with difficulty; clearly they could not detect the local constriction. It can be seen from the combination of circumstances which brought about this accident, how difficult it is to analyse this type of tunnel and the level of responsibility which must be borne by those concerned with their conservation.

\section{CONCLUSIONS}

Many writers have underlined that there is only one force which counts; it is time which destroys the finest of monuments, as so often our greatest hopes.

This Lecture has dealt with cases of old bridges adapting over a long period of time to soft soil conditions but yielding finally to the effects of modern traffic. It is time which, after a beneficial consolidation of the soil, accelerates the rotation of a tower. It is time which opens 
the pillars of Norman churches to the sky and widens their arches. It is time which attacks the most flexible members to transfer increased forces onto stiffer ones which yield in their turn. It is time which, in spite of 'reserve resistance', does not protect old domes from new settlements. It is time which carries the old buildings at the heart of Stockholm towards the river and bends their piles. It is time which renders old buildings vulnerable to neighbouring decompressions. Finally it is time which stamps its mark on the facings of tunnels.

However, if everything deforms and everything changes, the essential is to survive, and in spite of these blemishes, one cannot but admire the rational audacity of many anonymous builders whose instinct enabled them to understand the problems of soil and who have left us so many masterpieces from the past.

\section{ACKNOWLEDGFMENTS}

The Author wishes to express his thanks to Dr R. J. English of Simecsol (Paris) for his assistance in the preparation of the second part of the lecture, to Ove Arup and especially Mr B. O. Corbett for the written translation, and to Mrs J. Philpin Jones (Paris) for its oral expression.

\section{APPENDIX 1: MECHANICAL PROPERTIES OF MASONRY}

It is impossible to know what stresses result from the deformation of a masonry structure (e.g. a tunnel) unless its modulus of deformation is known. It is also necessary to know the limit stress levels, in order to determine the applicable factor of safety. The fact is that buildings have been erected for centuries past without any precise knowledge of all these data. It must be admitted that it is difficult to determine them, because of the heterogeneous nature of masonry. They depend on the quality of the stone, that of the mortar, the relative proportions of these two materials, the care used in construction and, finally, on age. Coulomb (1773) said, 'I found that a mortar made from four parts of sand to three of lime, and two years old, carried $50 \mathrm{lb} / \mathrm{in}^{2}$ perpendicular to the fracture plane. This last test, made in Martinique, cannot be generalized. The strength of mortar varies sometimes by a factor of two or even three, according to whether the climate is wet or dry, to the qualities of the sand, of the lime, and of the stone used in the body of the masonry, and according to the age of that masonry; nothing can be fixed about it, and individual tests must be made in each place.'

For the practical compressive strength of ordinary masonry laid with thick joints, it has for long been accepted that one-tenth of the breaking load of the weakest element (usually the mortar) should not be exceeded, this being in order to take account of the many unfavourable conditions which may occur during construction-negligence and irregularity in filling the joints, the use of stone not properly cleaned and incorrect mixing of mortar. For wrought stone masonry with joints, somewhat higher values may be accepted, the more so as the joints are thinner, up to one-fifth of the breaking load of the mortar for joints $0.5 \mathrm{~cm}$ thick. Again, for wrought stone set in cement grout, the value may be as much as one-quarter of the breaking load of the stone. Tensile strength is far from reaching that of the weaker of the two associated materials, for various reasons, the chief of which is poor adhesion of the mortar to the stone, due to the latter not being properly cleaned. As the strength of both the constituents is of the order of one-tenth of thecompressive strength, it can be seen that for masonry, it is usually much less than one-tenth of the compressive strength of the weaker material.

The reader is recommended to refer to the results published by Tourtay (1885) and discussed by Resal (1887) on the strength of various types of masonry and mortar at the time. All his rules must be regarded as pessimistic for cement mortars of more recent masonry works (since 1930). In France the elastic modulus has only once been measured (Resal, 1887) in an indirect experiment with a trial arch in hard ChâteauLandon stone ( 77 wrought stone voussoirs $1.10 \mathrm{~m}$ high and $0.50 \mathrm{~m}$ wide, separated by $0.012 \mathrm{~m}$ thick joints in Portland cement mortar forming an arch of $2.125 \mathrm{~m}$ rise with a chord of $37.886 \mathrm{~m}$, a radius of $85 \mathrm{~m}$ and a uniform thickness of $1.10 \mathrm{~m}$ ). Measurement of the depression of the keystone, and that of the same under an additional load made it possible to obtain a modulus $E$ of $25000 \mathrm{MN} / \mathrm{m}^{2}$. The Château-Landon stone itself had a breaking strength of $35 \mathrm{MN} / \mathrm{m}^{2}$ and a modulus of $35000 \mathrm{MN} / \mathrm{m}^{2}$. Thus, in the case of wrought stone masonry with $1.2 \mathrm{~cm}$ joints over a large area, the modulus of the masonry is of the same order as that of the stone. 


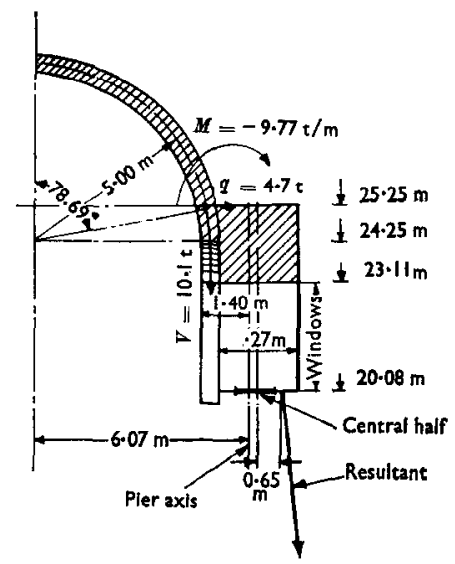

Fig. 61. Cluny III : resultant along line of thrust

Perrodil (1882) found a modulus of $3000 \mathrm{MN} / \mathrm{m}^{2}$ for brickwork in cement mortar. The compressive strength of the bricks was about eight to ten times less than that of the Chateau-Landon limestone. However, for ordinary millstone grit masonry in cement mortar of 1930 , we found a modulus of between 2000 and $3000 \mathrm{MN} / \mathrm{m}^{2}$ whilst the value of $E$ for the stone was of the order of $5000 \mathrm{MN} / \mathrm{m}^{2}$. This leads one to think that the modulus of masonry set with thin joints is of the order of $80 \%$ of that of the stone, whatever the mortar, and that for ordinary masonry, it is of the order of $50 \%$ for the mortars used at the beginning of the twentieth century, and of $20 \%$ for those of the previous century, and even less $(10 \%)$ for fat-lime mortars, these figures being put forward with the greatest reserve, in view of the few data available.

APPENDIX 2: STRUCTURES AND FOUNDATION OF CLUNY III-EQUILIBRIUM CONDITIONS

The Cluny III vault was not exactly a barrel vault of semi-circular section, but was slightly ogival; the mean radius of each arch was $(5.015+5.605) / 2=5.31 \mathrm{~m}$ with the centre staggered $0.44 \mathrm{~m}$ to right and left (this ogival effect was hidden at crossings only, every $7.80 \mathrm{~m}$, by ribs the intrados of which were circular, with a radius of $4.69 \mathrm{~m}$. The small value of this staggering made it possible to assimilate the vault, as a first approximation, to a circular arch of radius $R=5 \mathrm{~m}$, with its centre at the same level, but, because of the presence of the wall $2.27 \mathrm{~m}$ thick, which rises to $25.25 \mathrm{~m}$, it is necessary to take for this vault a half-opening $\theta_{0}=78^{\circ} .69$ with springs at the above level (Fig. 61).

\section{Calculation for elasticity}

The elasticity formulae for hyperstatic arches with fixed ends give the following, at the springs, for $\theta_{0}=$ $78^{\circ} \cdot 69$ ( 1.37 radians).

(a) horizontal thrust $Q=p R \times 0.64$, and here $R=5 \mathrm{~m}$ and $p=0.53 \times 2.4+0.2=1.47 \mathrm{t} / \mathrm{m}^{2}$, dead weight per square metre of middle fibre, where $0.53 \mathrm{~m}$ is the thickness of vault, 2.4 is the specific gravity of the stone and $0.2 \mathrm{t} / \mathrm{m}^{2}$ is the weight of the roof. Hence $Q=1.47 \times 5 \times 0.64=4.704 \mathrm{t}$;

(b) vertical reaction $V$ equal to the weight of the half-vault and the roof: $V=1.47 \times 5 \times 1.37=10.07 \mathrm{t}$;

(c) moment $M$ equal to $-0.266 p R^{2}: M=-0.266 \times 1.47 \times 25=-9.77 \mathrm{tm}$.

At the level of the windows, there are three windows of $1.10 \mathrm{~m}$, i.e. $3.30 \mathrm{~m}$ of opening which, in relation to the length of the span, $7.80 \mathrm{~m}$, corresponds to $48 \%$ of openings. Reducing the forces at the level of the foot of the windows, $+20.08 \mathrm{~m}$ on the centre line of the clerestory wall leads to the following: $V$ gives a stabilizing moment of $10.07 \times 1.40=14.10 \mathrm{tm}$ and $Q$ gives an overturning moment of $-4.7(25.25-20.08)=-24.30 \mathrm{t}$ which is added to the moment $M=-9.77 \mathrm{tm}$ to give, finally, an overturning moment of $14 \cdot 10-24 \cdot 30-$ $9 \cdot 77=-19 \cdot 97 \mathrm{tm}$.

The moment in the remaining solid part is therefore $-19.97 \times 1 /(1-0.48)=-38.40 \mathrm{tm}$.

As vertical forces we have, on the one hand $V=10.07 \mathrm{t}$ and, on the other, the weight of the walls from $25 \cdot 25 \mathrm{~m}$ to $20 \cdot 08$.

(a) from $25.25 \mathrm{t}$ to $23.11 \mathrm{~m}: 2.4 \times 2 \cdot 27(25 \cdot 25-23 \cdot 11)=11.65 \mathrm{t}$ which, as the $10.07 \mathrm{t}$ will act below upon $52 \%$ of solid, will give $(11 \cdot 65+10 \cdot 07) /(1-0 \cdot 48)=41 \cdot 77 \mathrm{t} / \mathrm{m}$;

(b) from $23.11 \mathrm{t}$ to $20.08 \mathrm{~m}: 2.4 \times 2.27(23.11-20.08)=16.5 \mathrm{t} / \mathrm{m}$. 
Finally, there is a weight of $41 \cdot 77 t+16 \cdot 51 t=58 \cdot 28 t$ to compare with an overturning moment of $-38 \cdot 40 t$. The resultant therefore passes through a point at $38.40 / 58 \cdot 28=0.65$ from the centre, beyond the central half, the eccentricity being $0 \cdot 65 / 2 \cdot 27=0 \cdot 28$.

\section{REFERENCES}

Abraham, P. (1934). Le rationalisme médiéval, p. 32, Fig. 15. Paris: Vincent Frcal.

Andersen, K. H. \& Friman Clausen, C. J. (1974). A fifty year settlement record of a heavy building on compressible clay. Conf. on Settlement of Structures, Cambridge, 71.

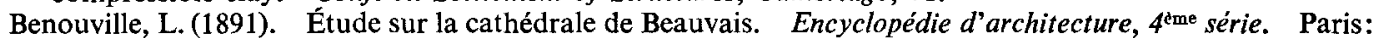
Libraries Imprimeries Réunies Ancienne Maison Morel, May et Motteroz.

Bjerrum, L. (1973). Problems of soil mechanics and construction in soft clays. 8th Int. Conf. Soil Mech. and Fdn Engng 3, 114-5.

Bratchell, G. E., Leggat, A. J. \& Simons, N. E. (1974). The performance of two large oil tanks founded on compacted gravel at Fawley. Conf. on Settlement of Structures, Cambridge, 3.

Breth, H. \& Amman, P. (1974). Time settlement and settlement distribution with depth in Frankfurt clay. Conf. on Settlement of Structures, Cambridge 141.

Breth, H. \& Chambosse, G. (1974a). Settlement behaviour of a nuclear reactor. Conf. on Settlement of Structures, Cambridge, 10.

Breth, H. \& Chambosse, G. (1974b). Settlement behaviour of buildings above subway tunnels in Frankfurt clay. Conf. on Settlement of Structures, Cambridge, 329.

Burland, J. B. \& Wroth, C. P. (1974). General report, Session 5. Conf. on Settlement of Structures, Cambridge, 611-764.

Chambosse, G. (1972). Das Verformungsverhalten das Frankfurter Tons beim Tunnelvortrieb. Darmstadt: Mitt. Technischen Hochschule.

Chami, E. (1975). Private communication.

Danyzy, A. A. H. (1778). Méthode générale pour déterminer la résistance qu'il faut opposer à la poussée des voûtes (27 fév., 1732). Histoire de la Sociétẻ Royale des Sciences établie à Montpellier 2, 40 . Lyon.

d'Elia, B. \& Grizolia, M. (1974). On the behaviour of a partially floating foundation on normally consolidated silty clays. Conf. on Settlement of Structures, Cambridge, 91.

Dowrick, D. J. \& Beckmann, P. (1971). York Minster structural restoration. Proc. Instn Civ. Engrs, Suppl., 93-156.

du Colombier P. (1953). Les chantiers des cathédrales. Paris: Picard.

Dunn, C. S. (1974). Settlement of a large raft foundation on sand. Conf. on Settlement of Structures, Cambridge, 14.

Heyman, J. (1967). Lecture given at Science Museum, London. Beauvais Cathedral. Trans. Newcomen Soc. 40 (1967-68), 15.

Heyman, J. (1972). Coulomb's memoir on statics. Cambridge: University Press.

Jimenez Salas, J. A. (1975). Private communication.

Kerisel, J. \& Lupiac, L. (1973). Contraintes exercées par le sol sur la station Auber à Paris. 8th Int. Conf. Soil Mech. and Fdn Engng, Moscow 2, 19.

Lagréné (1868). Arche d'essai des carrières de Souppes 2, 130.

Legget, R. F. (1973). Cities and geology. New York: McGraw Hill.

Lord, J. A. \& Nash, D. F. T, (1974). Settlement studies of two structures on Keuper Marl. Conf. on Settlement of Structures, Cambridge, 292.

Morton, K. \& Au, E. (1974). Settlements observed on eight structures in London. Conf. on Settlement of Structures, Cambridge, 183.

Nash, J. K. T. L. (1973). Discussion: London Bridge, planning and design. Proc. Instn Civ. Engrs 54, $726-732$.

Paquet, J. P. (1936). L'action du temps sur les édifices du Moyen Age. Ann. Inst. Tech. Bât. Trav. Publics 1, 1-10.

Perrodil, F. (1882). Arc d'expérience en maçonnerie de brique et ciment de Portland. Ann. Ponts Chaus. 2, 111 .

Rennie, Sir John (1875). Autobiography.

Resal (1887). Ponts en maçonnerie: stabilités des voûtes, 24, 28, 49, 339-398. Paris: Baudry.

Roscoe, K. H. (1970). Tenth Rankine Lecture. The influence of strains in soil mechanics. Géotechnique 20, No. 2, 129-170.

Saint-Benoit. Miracles. Livre VIII, Ch. 30, p. 12. In Mortet, V. (1911). Recueil de textes relatifs à l'histoire de l'architecture et a la condition des architectes en France au Moyen Age. Paris: Picard \& fils.

Schultze, E. (1971). Techniques de conservation et de restauration des monuments. Rome: University Faculty of Architecture International Study Centre for the conservation and restoration of cultural assets.

Skempton, A. W. (1964). Long-term stability of clay slopes. Géotechnique 14, No. 2, 77-101.

Thomas, C. (1885). Note sur l'influence des joints dans la résistance à l'écrasement des maçonneries de Pierre de taille. Ann. Ponts Chaus. 
Vefling, G. (1974). Settlement of the sugar silos on moraine clay in Griev, Denmark. Conf. on the Settlement of Structures, Cambridge, 242.

Viollet le Duc (1868). Dictionnaire raisonné de l'architecture française du XI ${ }^{\bullet}$ au XVI ${ }^{\ominus}$ siècle 4, 136 and 5, 524. Paris: Bance.

Vironnaud, L. \& Chassaing, R. (1959). Résistance à la compression des piliers en pierre de taille. Ann. Inst. Tech. Bât. Trav. Publics, No. 133, 84-104.

\section{BIBLIOGRAPHY}

Anon. (1972). Rapport d'enquête administrative sur les causes de l'accident du 16 juin, 1972 dans le tunnel ferroviaire de Vierzy. Supp. J. offic. Rép. Franc., 21/6/72.

Bjerrum, L. \& Eide, O. (1956). Stability of strutted excavations in clay. Géotechnique 6, No. 1, 32-47.

Bonet Laborderie (1974). Private communication.

Caroe \& Alban (1949). Old churches and modern craftsmen, ch. 6. London: Oxford University Press.

Chettoe, C. S. \& Henderson, W. (1957). Masonry arch bridges. Proc. Instn Civ. Engrs 7, 723-762.

Conant, K. J. (1942). Early mediaeval architecture. Harmondsworth: Penguin Books.

Conant, K. J. (1959). Carolingian and romanesque architecture. Harmondsworth: Penguin Books.

Cooling, L. F. \& Gibson, R. E. (1956). Settlement studies on structures in England; preliminary volume. Proc. Instn Civ. Engrs, 295-318.

Coulomb, C. A. (1773). Essai sur une application des règles de Maximis et Minimis à quelques problèmes de statique relatifs à l'architecture. C. R. Acad. Sciences, Paris, 6 and 18.

Couplet, P. (1726). De la poussée des voûtes. IIistoire de l'Académie Royale des Sciences, 106 (1728); 139 (1729); $113(1730)$.

Feline-Romany, E. (1866). Notice sur la construction d'une arche d'essai très surbaissée. Ann. Ponts Chaus. 2, 10.

Flaate, K. (1966). Stresses and movements in connexion with braced cuts in sand and clay. PhD thesis, University of Illinois.

Frezier, A. F. (1737-9). La théorie et la pratique des coupes des pierres et des bois pour la construction des voûtes et autres parties des bâtiments civils et militaires, ou traité de stéreotomie à l'usage de l'architecture. Strasbourg and Paris, three volumes.

Hahnloser, R. (1935). Villard de Honnecourt. Vienna: Anton Schroll.

Heyman, J. (1966). The stone skeleton. Int. Jnl Solid Structures 2, 249.

Heyman, J. (1969). The safety of masonry arches. Int. Jnl. Mech. Sci. 11, 363.

Henkel, D. J. Discussion: Conference on the correlation between calculated and observed stresses and displacements in structures.

Lc Blond, V. (1926). La Cathédrale de Beauvais. Paris: H. Laurens.

Luetkens, O. (1957). Bauliche Massnahmen zur Verhutung von Bergschaden, Fig. 20. Berlin: Springer Verlag.

Marra, M. (1971). Il rafforzamento statico del campanile di Burano. Riv. Ital. Geotec. 4.

Mortet, V. (1901). L'expertise de la cathédale de Chartres en 1316. 67 $7^{\text {tme }}$ Congrès archeol de France. Paris: A. Picard \& fils.

National Building Studies (1953). Test on road bridges. Research Paper 16, Nat. Bldg Studies.

Oursel, R. (1962). Invention de l'architecture romane. Introduction à la nuit des temps 6 . Paris: Zodiaque.

Paquet, J. P. (1958). Structures des monuments anciens et leur consolidation. Ann. Inst. Tech. Bât. Trav. Publics VI5-IX5, 115-140.

Peck, R. B. (1969). Deep excavations and tunnelling in soft ground: state of the art report. 7th Int. Conf. Soil Mech. and Fdn Engng, Mexico, 225-290.

Polshin, D. E. \& Tokar, R. A. (1957). Maximum allowable non-uniform settlement of structures. 4th Int. Conf. Soil Mech. Fdn Engng 1, 402.

Powys \& Wilson (1935). The repair of vaulted buildings. Jnl Roy. Inst. Brit. Arch 10, 1142-4.

Runacher, P. (1969). Pile driving and sheet bracing: their effects on adjacent structures. $\mathrm{PhD}$ thesis, Massachusetts Institute of Technology.

Salzman, L. F. (1952). Building in England down to 1840. Oxford: Clarendon Press, 25-27.

Schultze, E. (1973). Der schiefe Turm von Pisa. Aachen: Mitt. Tech. Hochschule.

Sejourne, P. (1913-16). Grandes voûtes. Bourges: Tardy Pigelet \& fils, three volumes.

Skempton, A. W. \& MacDonald, D. H. (1956). Allowable settlements of buildings. Proc. Instn Civ. Engrs 5, 727-768.

Skempton, A. W. (1973). St Paul's foundations. Unpublished report for Freeman Fox and Partners.

Ungewitter (1901). Lehrbuch der gotischen Konstruktionen. Tauchnitz, two volumes.

Venuat. M. (1970). Les deformations sous charge de béton durci. PhD thesis, University of Paris.

Viollet le Duc (1866). Article sur la restauration du point de vue des fondations dans Dictionnaire de l'Architecture 8, 2, 24-28. Paris: Morel. 
VOTE OF THANKS

Professor Kézdi, Vice-President for Europe of the International Society for Soil Mechanics and Foundation Engineering, said it was a great pleasure and indeed a great honour for him to propose the vote of thanks to Professor Kerisel for such a brilliant lecture in which had been combined theory and practice, logic and analysis, and sound engineering judgement. However, Professor Kézdi thought these were qualities which might be found in every lecture of Professor Kerisel's, and that he would like to put especial emphasis on the subject, the theme of the lecture, and also the presentation.

Professor Kerisel had directed the attention of the audience to the problems associated with old buildings and new ones. Those present were always very eager to get information about the performance of old structures designed and erected on the basis of soil mechanics, using sophisticated theories and methods of construction, and to find out also whether the soil would know something about soil mechanics and about their theories. So measurements during and after construction work were performed, but these measurements did not go very far because it was always difficult to get them financed. Today there exist-and Professor Kerisel had pointed this out-many examples of age-old buildings, and it could be seen whether they performed well, or not. It was always very interesting to find out why these structures failed, or did not fail; this would serve knowledge and future work. Knowledge of the performance of such structures was not easy to obtain, but some additional boring, additional investigation of the soil, and the use of modern methods would add much to knowledge for future work.

Professor Kédzi said he well remembered Professor Terzaghi giving a lecture in London and mentioning that intuition was a very good thing at all times of structural endeavour. He had mentioned for example the Hagia Sophia mosque in Istanbul; the cupola had collapsed twice before the final structure had been built. This had been due to the performance of the foundation, so intuition had worked very well while designing the superstructure but had stopped when it came to the design of the foundation; therefore this intuition would solve some problems, but not all.

There were other cases: for example, in Egypt, the foundation of some very old temples had been made in the following way. In the Nile Valley where the surface was covered by a thick deposit of very soft layers, builders had dug a hole as deep as the height of the column and filled it with sand, then put the column on top of it. This was exactly the same as the modern method used to accelerate the rate of consolidation. Intuition would therefore do much for the foundation engineer also.

Professor Kézdi said that he could quote some cases in his own country where he was sure no one present would dare design a retaining wall of such dimensions, where the foundation was eight inches and the dimensions very small; according to every calculation the retaining wall had to tilt, but it did not. It might be found out why these things happened, why something failed and something else did not fail.

He said that this treasury of information opened up by Professor Kcrisel in his lccture dcserved very careful consideration from which information for future work might be obtained.

The presentation of Professor Kerisel's lecture was in the best sense French, and it was really fascinating for the audience. Professor Kézdi was sure that the audience would support and agree with him in proposing a hearty vote of thanks to Professor Kerisel for having given this wonderful lecture. Their thanks would go also to the British Geotechnical Society for having organized an enjoyable evening, and to everyone involved in the preparations for the lecture. One who deserved special mention was Mr Brian Corbett, who had dealt with the translation of the lecture, and also the staff of the Institution of Civil Engineers. 